Review

\title{
A Journey from June 2018 to October 2021 with $N, N$-Dimethylformamide and $N, N$-Dimethylacetamide as Reactants
}

\author{
Jacques Muzart
}

check for updates

Citation: Muzart, J. A Journey from June 2018 to October 2021 with $\mathrm{N}, \mathrm{N}$-Dimethylformamide and $\mathrm{N}, \mathrm{N}$-Dimethylacetamide as Reactants. Molecules 2021, 26, 6374. https:// doi.org/10.3390/molecules26216374

Academic Editor: Michal Szostak

Received: 23 August 2021

Accepted: 15 October 2021

Published: 21 October 2021

Publisher's Note: MDPI stays neutral with regard to jurisdictional claims in published maps and institutional affiliations.

Copyright: (C) 2021 by the author. Licensee MDPI, Basel, Switzerland. This article is an open access article distributed under the terms and conditions of the Creative Commons Attribution (CC BY) license (https:/ / creativecommons.org/licenses/by/ $4.0 /)$.
Institut de Chimie Moléculaire de Reims, CNRS-Université de Reims Champagne-Ardenne, B.P. 1039, CEDEX 2, 51687 Reims, France; jacques.muzart@univ-reims.fr

Abstract: A rich array of reactions occur using $N, N$-dimethylformamide (DMF) or $N, N$-dimethyl acetamide (DMAc) as reactants, these two amides being able to deliver their own $\mathrm{H}, \mathrm{C}, \mathrm{N}$, and $\mathrm{O}$ atoms for the synthesis of a variety of compounds. This account highlights the literature published since June 2018, completing previous reviews by the author.

Keywords: $N, N$-dimethylformamide; DMF; $N, N$-dimethylacetamide; DMAc; amination; amidation; formylation; cyanation; insertion; cyclization

\section{Introduction}

In 2009, I wrote a review highlighting that $N, N$-dimethylformamide (DMF) is much more than a solvent of organic and organometallic chemistry [1]. A few years later, I was successively solicited for a book chapter and a review devoted to the use of DMF and $N, N$-dimethylacetamide (DMAc) as reagents in synthesis, which have been written with J. Le Bras [2,3]. Reviews related to the DM (DM = DMF or DMAc) reactivity have been published by others [4-7].

The purpose is now to highlight the recent literature, focusing on atom transfer from DM to substrates. A few older reports, useful to place the subject in the appropriate context, or omitted in the previous reviews are included. The processes which necessitate the prerequisite synthesis of DM derivatives such as the Vilsmeier-Haack reagents [8,9] and DMF dimethyl acetal [10] are discarded. Color equations, based on literature proposals, allow easily visualizing the DM atom(s) origin. DM may act as a nucleophilic or electrophilic reagent; neutral, ionic, and radical species, such as those depicted in Scheme 1, may be key intermediates. The reaction mechanisms will be, at best, briefly commented on. 


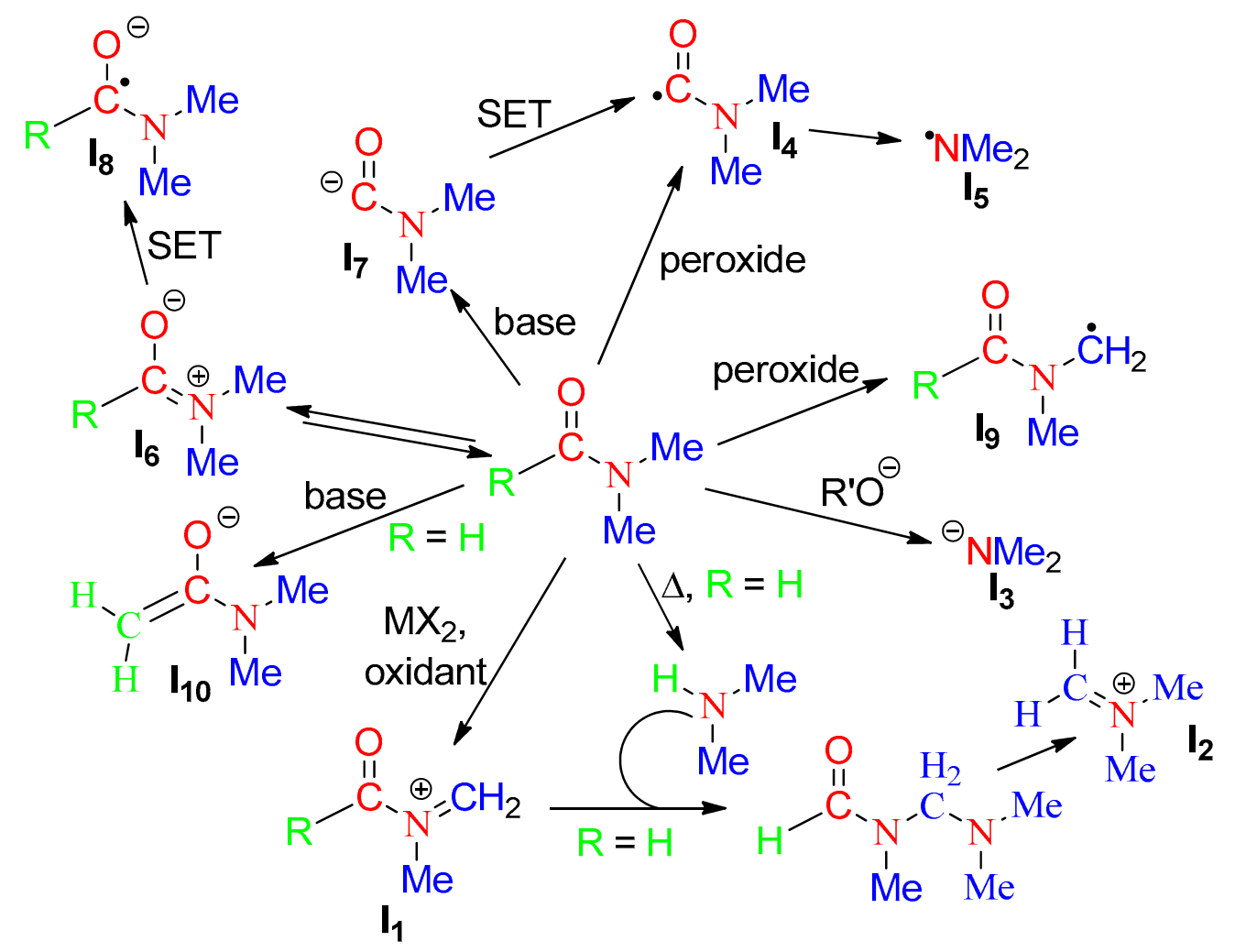

Scheme 1. Plausible key species implicated in the delivery of DM fragments $(R=H$ or $M e)$.

\section{C Fragment}

Under aerobic conditions, $\mathrm{Cu}^{\mathrm{II}}$ mediated the cyanation of (hetero)arenes by the combination of DMF and ammonium iodide (Scheme 2). Both Sun/Cheng's [11] and Jiang/Ji's [12] teams assumed a mechanism involving decomposition of $\mathrm{NH}_{4} \mathrm{I}$, into $\mathrm{NH}_{3}$ and production of $\mathrm{CN}^{\ominus}$ from the addition of $\mathrm{NH}_{3}$ to $\mathbf{I}_{\mathbf{1}}$ (Scheme 2c). The first team proposed the formation of $\mathrm{ArCuCN}$ from $\mathrm{ArH}$ and $\mathrm{Cu}^{\mathrm{II}}$ followed by reductive elimination, while the second team suggested the iodination of $\mathrm{ArH}$ and subsequent $\mathrm{Cu}^{\mathrm{II}}$-mediated cyanation. A recyclable catalyst, obtained from the impregnation of $\mathrm{Cu}\left(\mathrm{NO}_{3}\right) \cdot 3 \mathrm{H}_{2} \mathrm{O}$ over mesoporous siliceous SBA-15 followed by calcination at $450{ }^{\circ} \mathrm{C}$, was used for cyanation of $N$-substituted indoles with $\mathrm{NH}_{4} \mathrm{I}$ and DMF [13]. The $\mathrm{NH}_{4} \mathrm{I} / \mathrm{DMF}$ association has also been used for syntheses, as reported in Chinese patents [14-18].

$\mathrm{Cu}^{\mathrm{II}}$-catalyzed cyanation of (hetero)aryl halides arose using ceric ammonium nitrate and $\mathrm{K}_{2} \mathrm{CO}_{3}$ in DMF (Scheme 2d) [19]. According to Bora and co-workers, $\mathrm{K}_{2} \mathrm{CO}_{3}$ reacts with $\left[\mathrm{Ce}\left(\mathrm{NO}_{3}\right)_{6}\right]\left(\mathrm{NH}_{4}\right)_{2}$ leading to $\left(\mathrm{NH}_{4}\right)_{2} \mathrm{CO}_{3}$ which undergoes decomposition providing $\mathrm{NH}_{3}$. The $\mathrm{Cu}^{\mathrm{II}}$-catalyzed reaction of the latter with $\mathrm{DMF}$ affords $\mathrm{Cu}^{\mathrm{I}}$ and $\mathrm{CN}^{\ominus}$. The reaction of $\mathrm{CN}^{\ominus}$ with $\mathrm{ArCuX}$ proceeds as disclosed in Scheme 2c. Regeneration of the catalyst is assumed with ceric ammonium nitrate. 


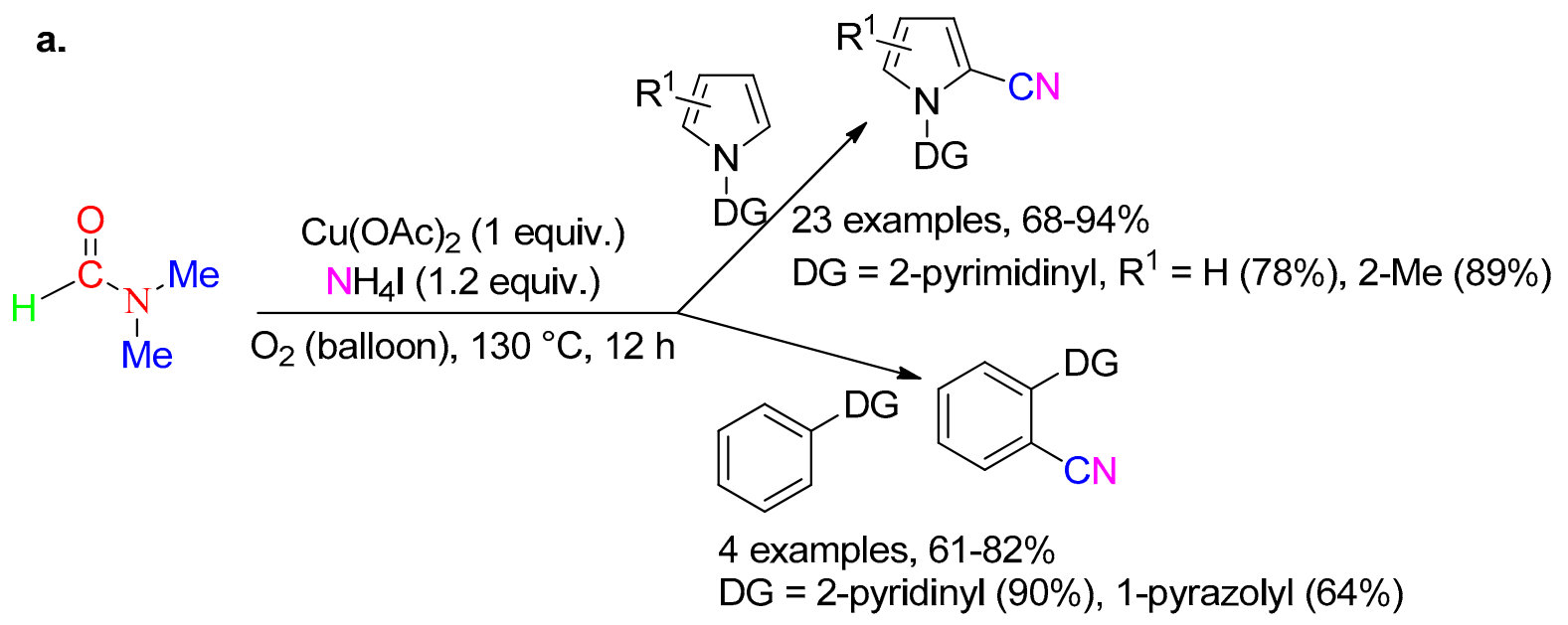

b.

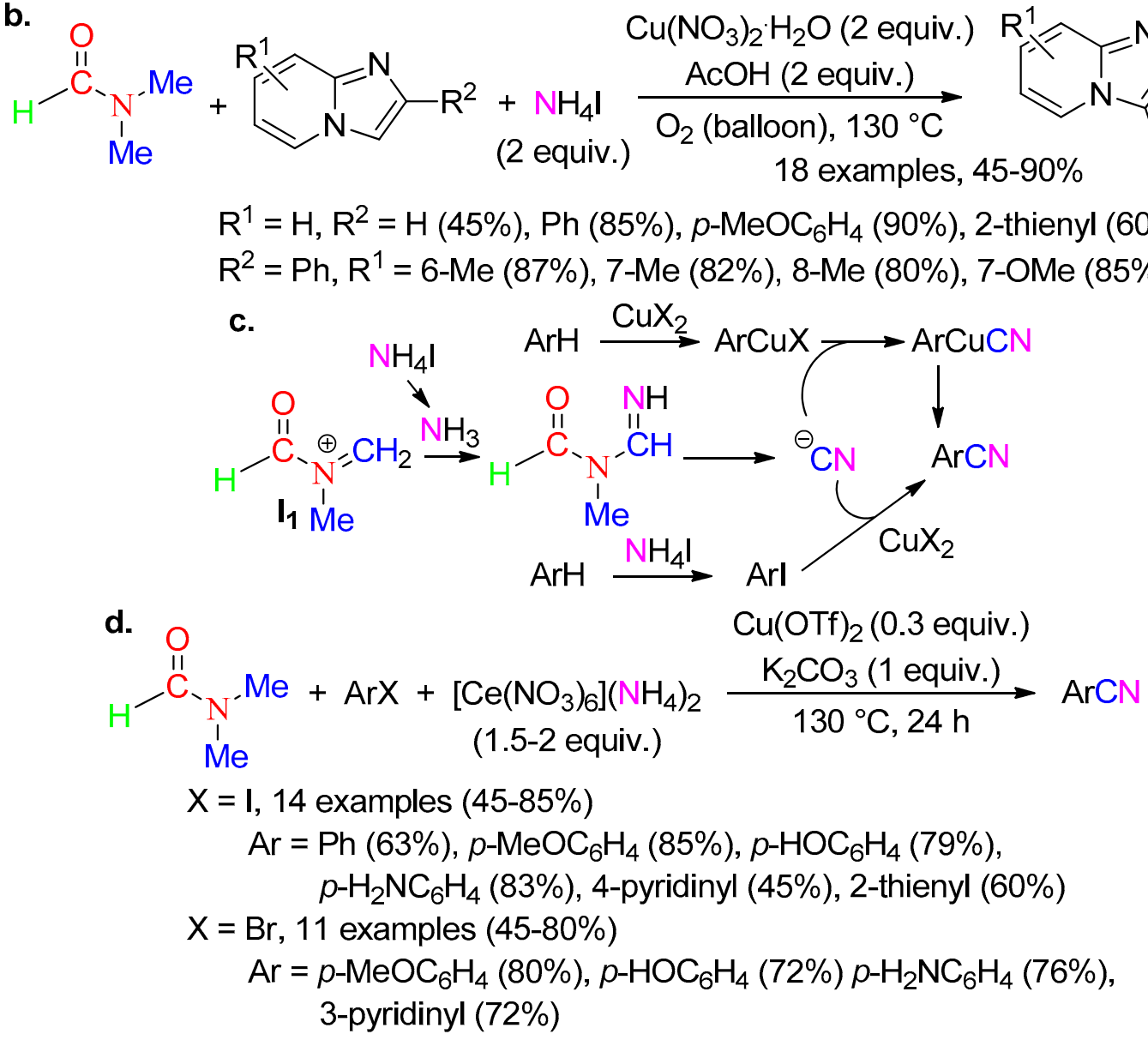

Scheme 2. Cyanation of (hetero)arenes and (hetero)aryl halides.

\section{CH Fragment}

When carried out in the absence of ammonium iodide, the above $\mathrm{Cu}$-mediated reaction of imidazo [1,2-a]pyridines led to the formylation of the C3-H bond (Scheme 3( $\left.\mathrm{a}_{1}\right)$ ) [12]. The Jiang/Ji team suggested the nucleophilic addition of the substrate to $\mathbf{I}_{\mathbf{1}}$ followed by homolytic cleavage of the $\mathrm{C}-\mathrm{N}$ bond (Scheme $3\left(\mathrm{a}_{2}\right)$ ). Trapping the radical species with oxygen affords a peroxy radical, the decomposition of which gives the product.

According to Lin and co-workers and a reaction with ${ }^{18} \mathrm{O}$-labeled water, the annulative formylation of $o$-alkynylanilines depicted in Scheme $3\left(\mathrm{~b}_{1}\right)$ occurs via activation of the triple bond by coordination to $\mathrm{Cu}^{\mathrm{II}}$, favoring 5-endo-dig cyclization of the substrate leading 
to a $\mathrm{Cu}$ complex which inserts into the $\mathrm{C}=\mathrm{N}$ bond of $\mathrm{I}_{2}$ [20]. The subsequent reductive $\beta$-H elimination affords an iminium ion that reacts with water to deliver the product (Scheme 3( $\left.b_{2}\right)$ ).

$$
\begin{aligned}
& \text { al. } \\
& \mathrm{R}^{1}=\mathrm{H}, \mathrm{R}^{2}=\mathrm{H}(35 \%), \mathrm{Ph}(82 \%), p-\mathrm{MeOC}_{6} \mathrm{H}_{4}(80 \%), 2 \text {-thienyl }(40 \%) \\
& \mathrm{R}^{2}=\mathrm{Ph}, \mathrm{R}^{1}=7-\mathrm{Me}(80 \%), 6-\mathrm{F}(65 \%), 6-\mathrm{Ph}(75 \%), 6-\mathrm{CF}_{3}(45 \%) \\
& \mathrm{R}^{2}=\mathrm{H}, \mathrm{R}^{1}=7-\mathrm{Cl}(30 \%), 7-\mathrm{CO}_{2} \mathrm{Me}(22 \%)
\end{aligned}
$$

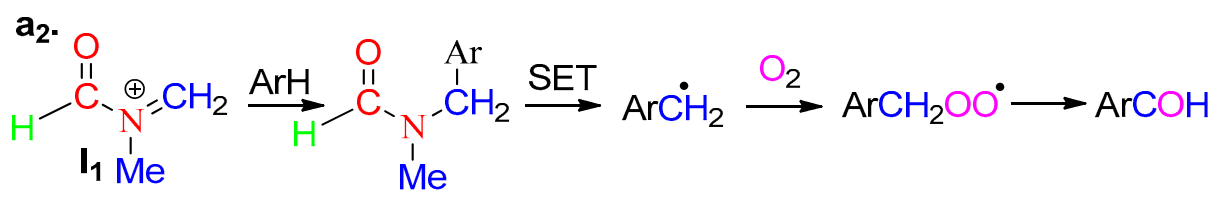

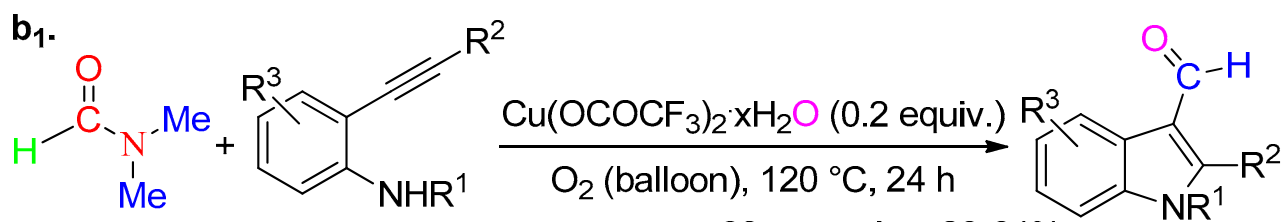
38 examples, $20-64 \%$

$$
\begin{aligned}
& R^{1}=R^{3}=H, R^{2}=P h(52 \%), 2 \text {-thienyl (25\%) } \\
& R^{3}=H, R^{2}=P h, R^{1}=P h(55 \%), C y(36 \%), S_{2}\left(p-M_{e} H_{6} H_{4}\right)(58 \%) \\
& R^{3}=H, R^{2}=\text { cyclopropyl, } R^{1}=B n\left(33 \%{ }^{a}\right) \\
& R^{1}=B n, R^{2}=P h, R^{3}=5-B r(50 \%)
\end{aligned}
$$

aPlus the debenzylation adduct (22\%).<smiles>[R]C#Cc1ccccc1N=[R]</smiles>

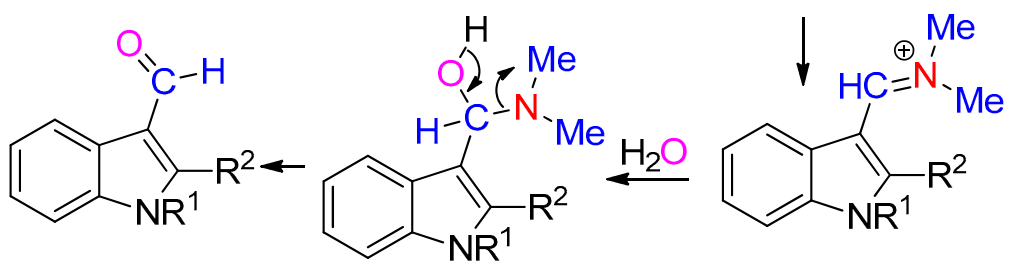

Scheme 3. Formylations involving Me.

The S. Zhang/Jiang/Jia [21], Xie/Wang/Shang [22], and Weng/Ackermann [23] teams reported annulations with the insertion of a methine fragment (Scheme 4). The addition of hydrazide to $\mathbf{I}_{\mathbf{1}}$ is the key step to produce the 1,3,4-oxadiazole (Scheme 4a,b) [21] while the synthesis of the pyrazolo[3,4-b]pyridines derivatives (Scheme 4c) [22] is, in fact, due to a Friedel-Crafts-type nucleophilic addition of pyrazol-5-amine to the 2methylenecyclohexane-1,3-dione (Scheme 4d). The latter is formed by coordination of diazo compound to the $\mathrm{Rh}$ catalyst leading to a rhodium-carbene which inserts into a C$\mathrm{H}$ bond of $\mathrm{DM}$, subsequent $\beta$-nitrogen elimination delivering the methylene dione and RCONHMe. The recent cyclization of 4-arylaminocoumarins (Scheme 4e) [23] involves 
the electrochemically NaI-mediated formation of $\mathbf{I}_{\mathbf{1}}$ and a radical derivative of the substrate which react together afford the coumarin derivative substituted with $\mathrm{CH}_{2} \mathrm{NMeCOH}$ (Scheme $4 \mathrm{f}$ ). Elimination of $\mathrm{HCONHMe}$ and subsequent $\mathrm{NaHSO}_{3}$-mediating cyclization followed by aromatization provide $6 \mathrm{H}$-chromeno[4,3-b]quinolin-6-one.

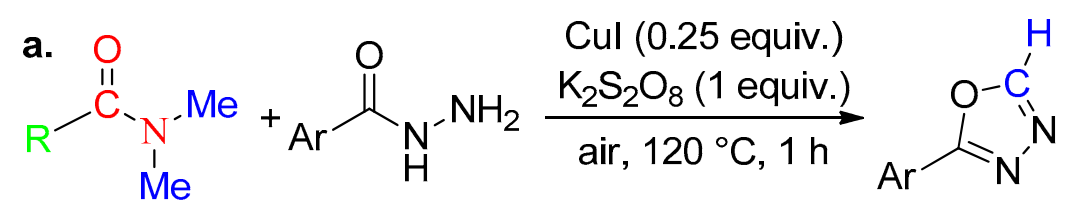

$\mathrm{R}=\mathrm{H}, 19$ examples, $0-75 \%$

$\mathrm{Ar}=\mathrm{Ph}(68 \%), p-\mathrm{NCC}_{6} \mathrm{H}_{4}(75 \%), m-\mathrm{ClCC}_{6} \mathrm{H}_{4}(74 \%)$,

2-furyl (40\%), 2-thienyl (38\%), 3-pyridinyl (0\%)

$\mathrm{R}=\mathrm{Me}, \mathrm{Ar}=\mathrm{Ph}\left(32 \%{ }^{\mathrm{a}}\right)$

a Using 0.1 equiv. of Cul.

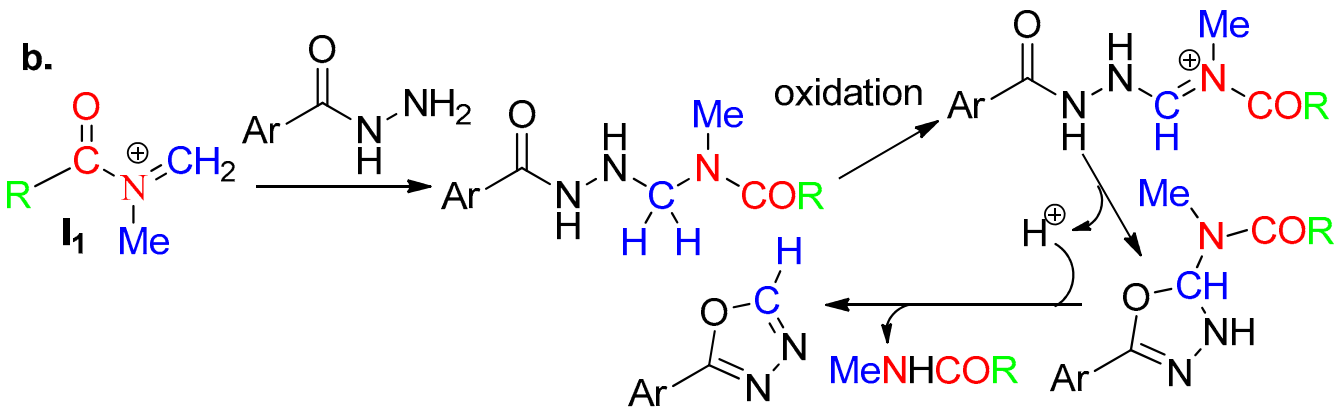

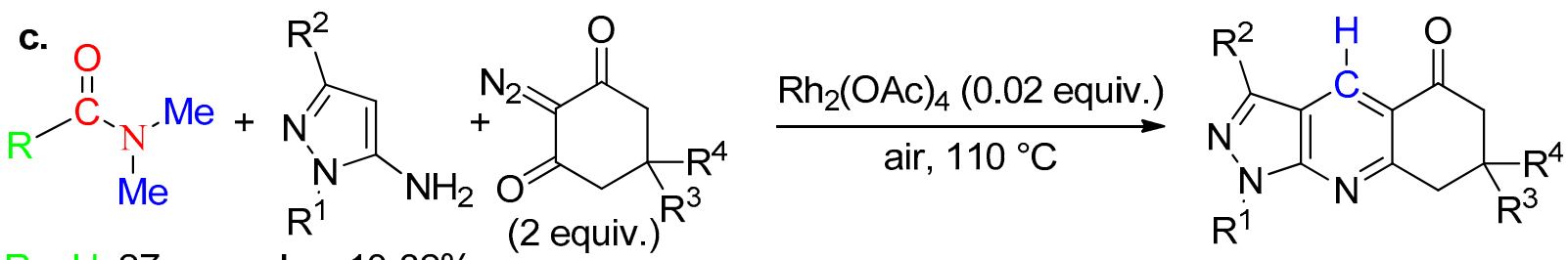

$\mathrm{R}=\mathrm{H}, 27$ examples, 10-82\% $\left(2\right.$ equiv.) $R^{3}$ $\mathrm{R}^{1}$

$\mathrm{R}^{2}=\mathrm{R}^{3}=\mathrm{R}^{4}=\mathrm{Me}, \mathrm{R}^{1}=\mathrm{Me}(21 \%), \mathrm{Ph}(75 \%), m-\mathrm{BrC}_{6} \mathrm{H}_{4}(65 \%), p-\mathrm{FC}_{6} \mathrm{H}_{4}(65 \%), o-\mathrm{FC}_{6} \mathrm{H}_{4}(10 \%)$

$\mathrm{R}^{1}=\mathrm{R}^{2}=\mathrm{Ph}, \mathrm{R}^{3}=\mathrm{R}^{4}=\mathrm{Me}(76 \%)$

$R^{1}=P h, R^{3}=H, R^{4}=M e, R^{2}=M e(62 \%), P h(79 \%)$

$\mathrm{R}^{3}=\mathrm{R}^{4}=\mathrm{H}, \mathrm{R}^{2}=\mathrm{Me}, \mathrm{R}^{1}=\mathrm{Ph}(50 \%), p-\mathrm{ClC}_{6} \mathrm{H}_{4}(61 \%)$

$\mathrm{R}=\mathrm{Me}, \mathrm{R}^{2}=\mathrm{R}^{3}=\mathrm{R}^{4}=\mathrm{Me}, \mathrm{R}^{1}=\mathrm{Ph}(55 \%)$

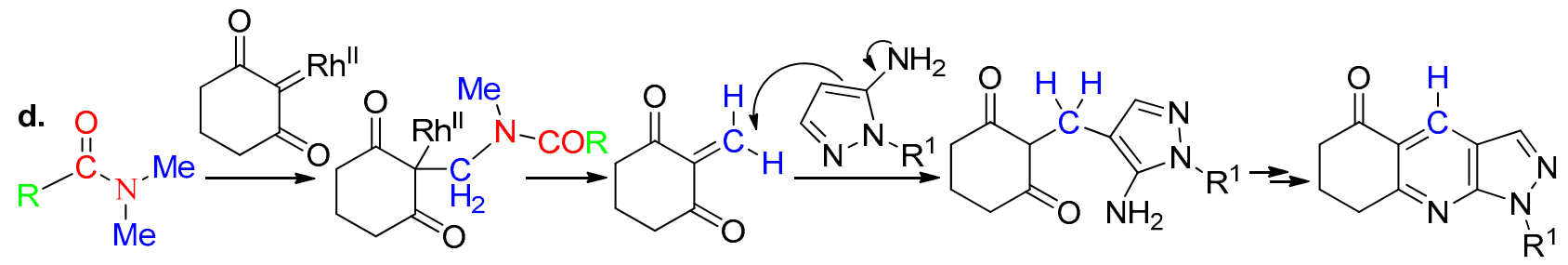

Scheme 4. Cont. 

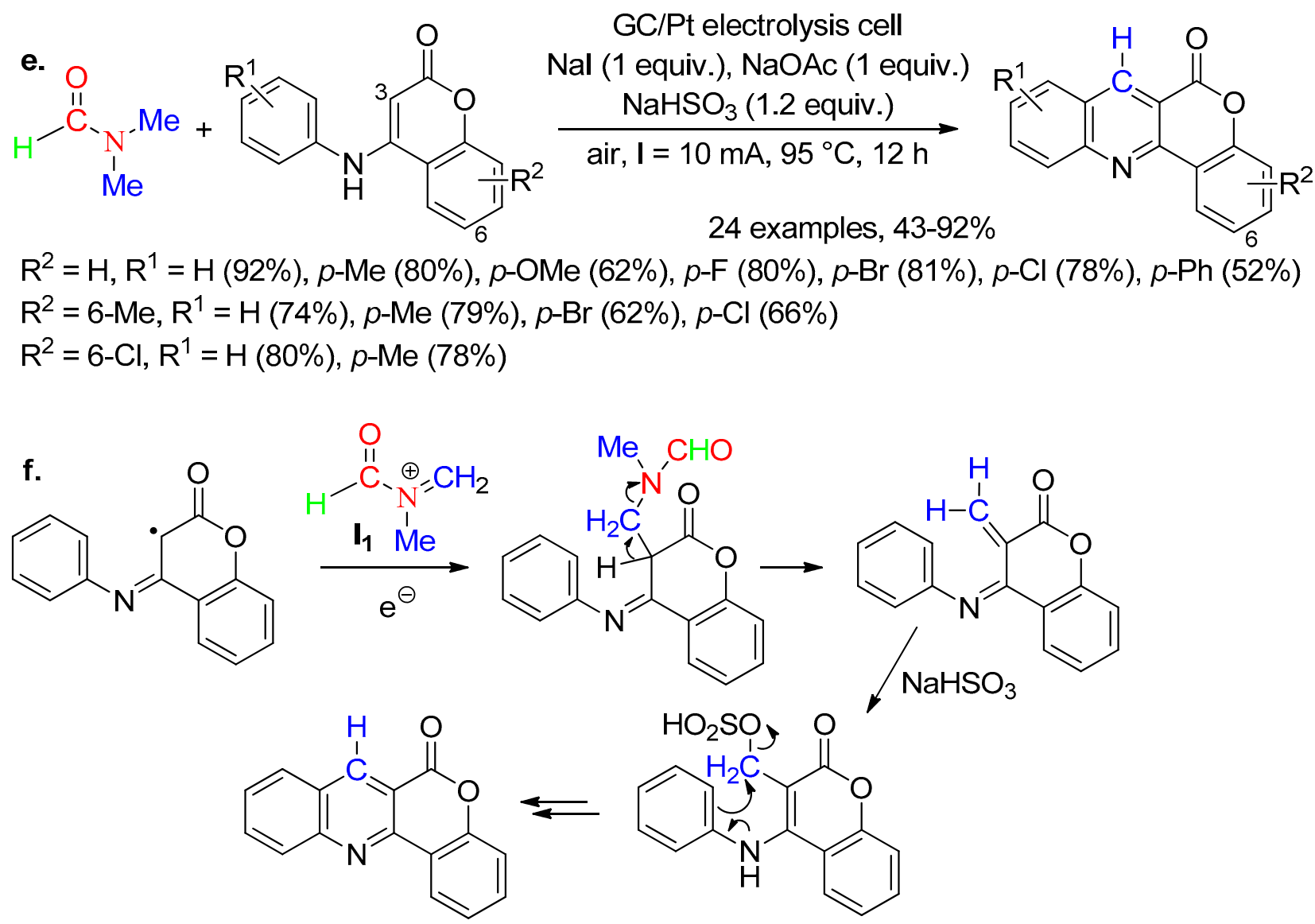

Scheme 4. Annulation with methine insertion.

An annulation reaction involving the insertion of a nitrogen atom and a $\mathrm{CH}$ fragment has been reported from the heating of aromatic ketones $\left(\mathrm{ArCOCH}_{2} \mathrm{R}^{1}\right)$ in DMF or DMAc in the presence of ammonium acetate and Selectfluor (Scheme 5( $\left.\left.\mathrm{a}_{1}, \mathrm{a}_{2}\right)\right)$ [24]. The key step leading to symmetrical pyridines (Scheme $5\left(\mathrm{a}_{2}\right)$ ) is the nucleophilic addition of the vinylamine $\operatorname{ArC}\left(\mathrm{NH}_{2}\right)=\mathrm{CHR}^{1}$ formed from the substrate and ammonium acetate, to $\mathbf{I}_{\mathbf{1}}$ formed from DMF and Selectfluor (Scheme $5\left(a_{3}\right)$ ). The resulting intermediate $\mathrm{Ar}(\mathrm{C}=\mathrm{NH}) \mathrm{CHR}^{1}-\mathrm{CH}_{2} \mathrm{NMe}$ $\mathrm{COH}$ undergoes elimination of $\mathrm{HNMeCOH}$ giving $\operatorname{Ar}(\mathrm{C}=\mathrm{NH}) \mathrm{CR}^{1}=\mathrm{CH}_{2}$. A nucleophilic attack of the latter by $\mathrm{ArCOCH}_{2} \mathrm{R}^{1}$ is followed by annulation and aromatization. The unsymmetrical pyridines (Scheme $\left.5\left(\mathrm{a}_{1}\right)\right)$ are formed via a rather similar mechanism which starts with homo-condensation of the substrate. The synthesis of 2,4-diphenylpyridine from acetophenone, $\mathrm{NH}_{4} \mathrm{Oac}$, and DMF or DMAc using $\mathrm{NH}_{4} \mathrm{I}$ instead of Selectfluor was previously reported but in no more than $6 \%$ yield [25]. In contrast, the synthesis of such compounds was efficiently catalyzed using $\mathrm{RuCl}_{3}[3,26]$ or a recyclable hypercrosslinked polymer-immobilized ruthenium catalyst noted as $\mathrm{HCP}-\mathrm{PPh}_{3}-\mathrm{Ru}$ (Scheme 5b) [27].

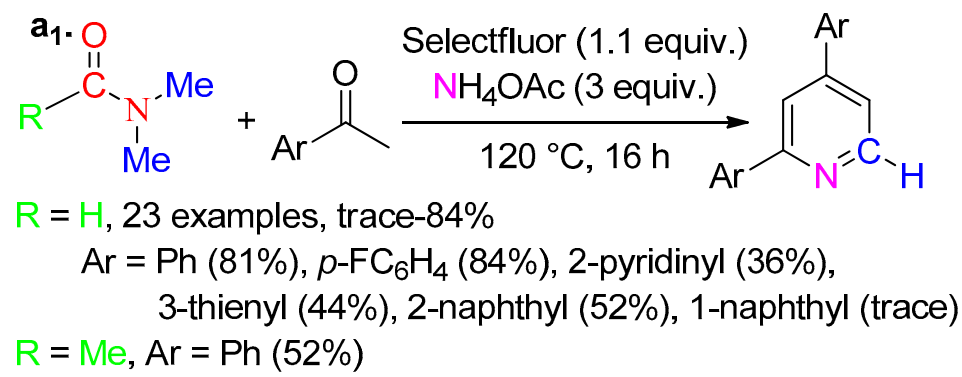




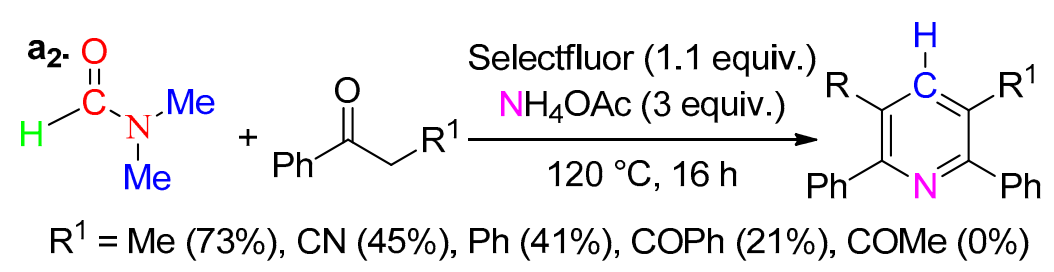

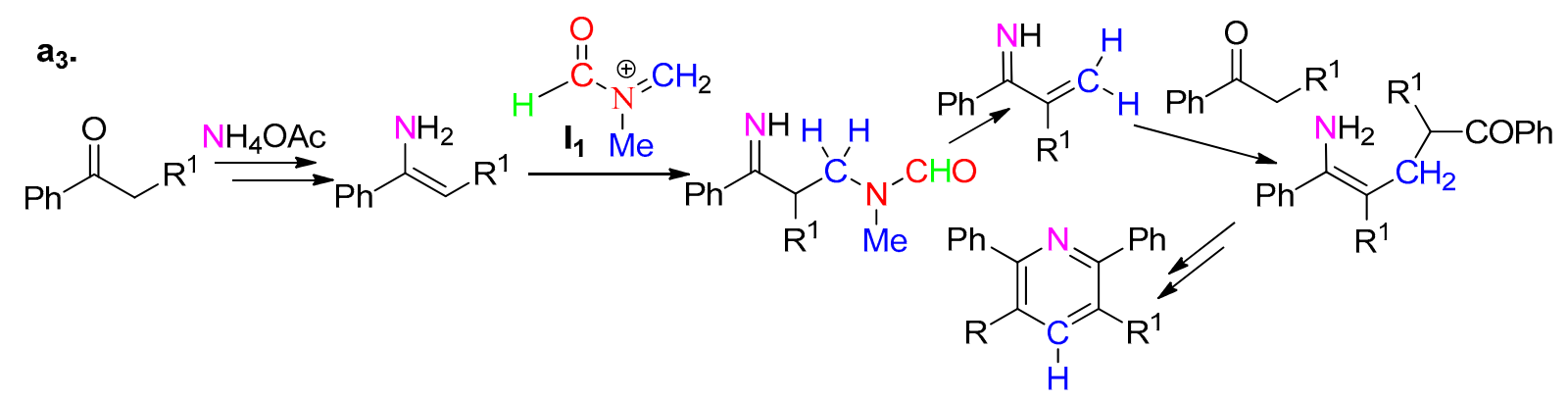

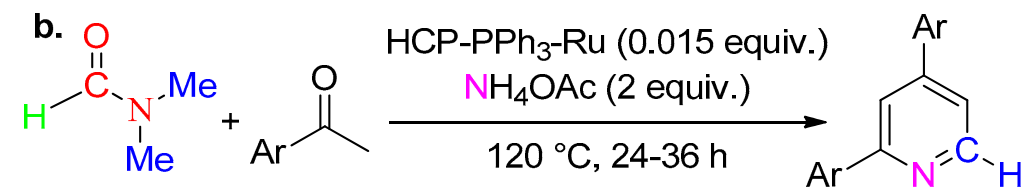

15 examples, $21-85 \%$ $\mathrm{Ar}=\mathrm{Ph}(85 \%), p-\mathrm{FC}_{6} \mathrm{H}_{4}(76 \%)$, 2-naphthyl (37\%), 3-thiophenyl (52\%)

Scheme 5. Annulation with insertion of both nitrogen and methane.

\section{4. $\mathrm{CH}_{2}$ Fragment}

Copper acetate associated with $N$-fluorobenzenesulfonimide promoted an efficient one-pot three-component condensation leading to $\alpha$-amino nitriles (Scheme 6) [28]. The reaction involves the addition of a secondary aromatic amine to $\mathbf{I}_{\mathbf{1}}$, giving $\operatorname{ArNR}^{1} \mathrm{CH}_{2}$ $\mathrm{NMeCOH}$ which is converted into $\mathrm{ArNR}^{1}=\mathrm{CH}_{2}{ }^{\oplus}$ via cleavage of the $\mathrm{CH}_{2}-\mathrm{NMe}$ bond. Subsequent reaction of the iminium ion with TMSCN provides the $\alpha$-amino nitrile.

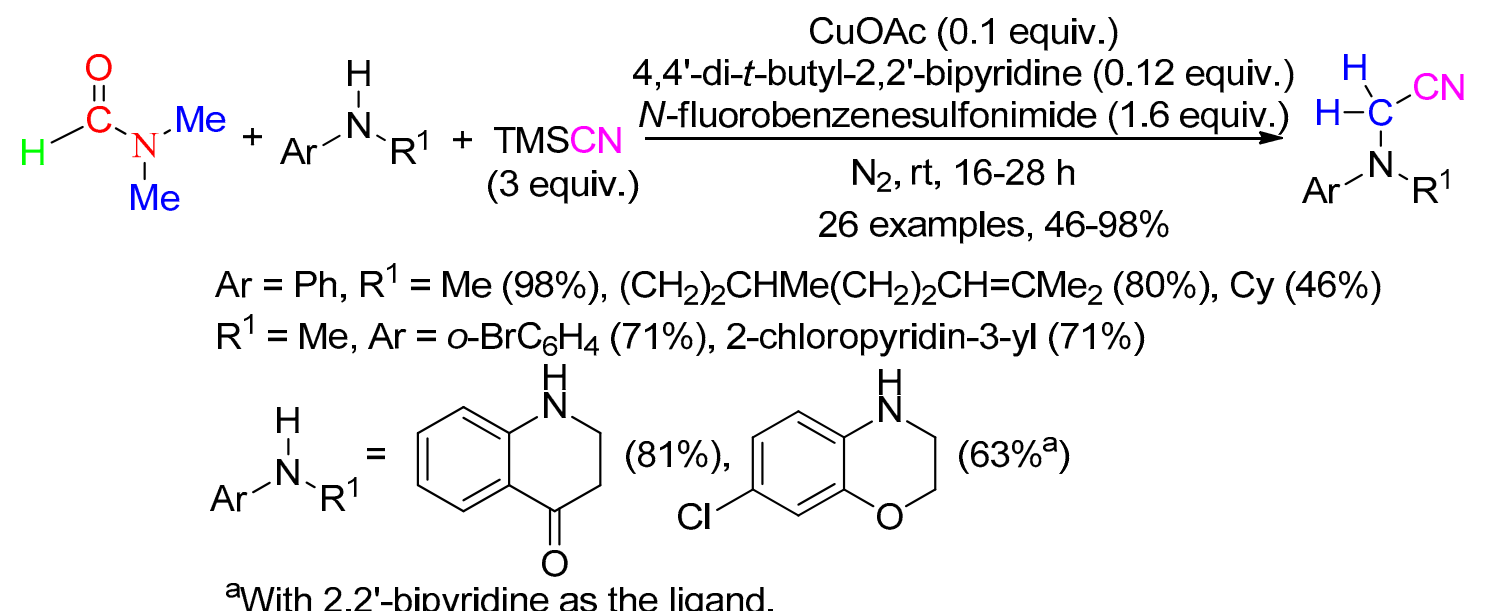

Scheme 6. Substitution of secondary aromatic amines with the $\mathrm{CH}_{2} \mathrm{CN}$ moiety.

\section{NC Fragment}

To the best of our knowledge, no new report concerned cyanation reactions using the NC fragment of DM. 


\section{6. $\mathrm{NMe}_{2}$ Fragment}

\subsection{Aryl Halides and Tosylates}

The amination of (hetero)aryl halides or tosylates with DM has been carried out under various conditions (Scheme 7) [29-32]. With DMF, these reactions could occur via reaction of the substrate with $\mathrm{HNMe}_{2}$ produced from thermal or catalytic decomposition of DMF. Under basic conditions, an aromatic nucleophilic substitution $\left(S_{N} A r\right)$ process has been discarded and Gong's team pointed out that the mechanism is unclear [30]. Under the experimental conditions of Scheme $7 \mathrm{~d}$, Ni-catalyzed-activation of the $\mathrm{C}-\mathrm{N}$ bond of DM could participate in the process [33,34], but the presence of water could disfavor the coordination of DM to the transition metal [35]. Cleavage of the $\mathrm{C}-\mathrm{N}$ bond of amides may, however, arise under transition-metal-free conditions [36].

Recently, the Kozlowski/Handa team disclosed the dimethylamination of fluoro (hetero)arenes with DMF in the presence of ammonium formate and light (Scheme 7e) [37]. According to computational studies and control experiments, the Van der Waals complex formed from the electron-deficient fluorinated aromatic ring and DMF evolves under light toward a charge transfer complex stabilized by ammonium formate. The subsequent decomposition leads to $\mathrm{ArNMe}_{2}$ or $\mathrm{ArF}$ and $\mathrm{HNMe}_{2}$. The $\mathrm{S}_{\mathrm{N}} \mathrm{Ar}$ reaction between the two latter species could also contribute to the product formation [37]. Under the optimum conditions, switching the solvent of the reaction of octafluoronaphthalene from DMF to DMAc decreased the yield of 1,3,4,5,6,7,8-heptafluoro- $N, N$-dimethylnaphthalen-2-amine from $80 \%$ to traces.

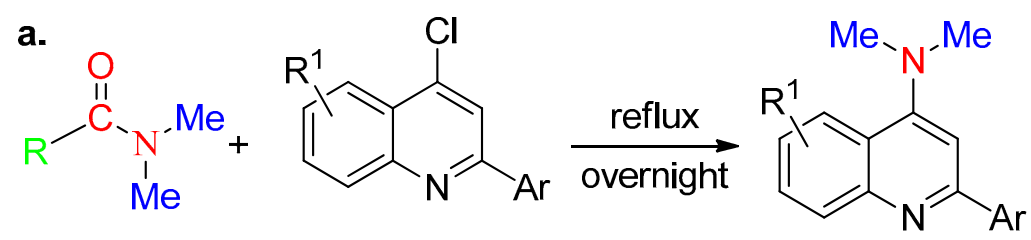

$$
\begin{aligned}
& \mathrm{R}=\mathrm{H}, 6 \text { examples, 56-91\% } \\
& \mathrm{R}^{1}=\mathrm{H}, \mathrm{Ar}=\mathrm{Ph}(75 \%), p-\mathrm{MeOC}_{6} \mathrm{H}_{4}(58 \%) \\
& \mathrm{Ar}=\mathrm{Ph}, \mathrm{R}^{1}=6-\mathrm{FC}_{6} \mathrm{H}_{4}(91 \%), 8-\mathrm{FC}_{6} \mathrm{H}_{4}(56 \%) \\
& R=\mathrm{Me}, \mathrm{R}^{1}=\mathrm{H}, \mathrm{Ar}=\mathrm{Ph}(11 \%)
\end{aligned}
$$

b.

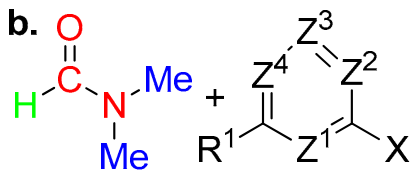

$$
\underset{\text { air, } 100^{\circ} \mathrm{C}, 24 \mathrm{~h}}{\stackrel{\mathrm{KOH}}{(2.5 \text { equiv })}}
$$

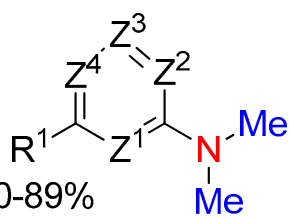

$\mathrm{R}^{1}=\mathrm{H}, \mathrm{Z}^{1}=\mathrm{Z}^{2}=\mathrm{Z}^{3}=\mathrm{CH}, \mathrm{Z}^{4}=\mathrm{CNO}_{2}, \mathrm{X}=\mathrm{I}(89 \%), \mathrm{Br}(83 \%), \mathrm{Cl}(71 \%), \mathrm{F}(81 \%)$

$\mathrm{R}^{1}=\mathrm{H}, \mathrm{Z}^{1}=\mathrm{Z}^{2}=\mathrm{Z}^{3}=\mathrm{CH}, \mathrm{Z}^{4}=\mathrm{N}, \mathrm{X}=\mathrm{I}(82 \%), \mathrm{Br}(73 \%), \mathrm{Cl}(21 \%)$

$\mathrm{R}^{1}=\mathrm{H}, \mathrm{Z}^{2}=\mathrm{Z}^{4}=\mathrm{CH}, \mathrm{Z}^{1}=\mathrm{Z}^{3}=\mathrm{N}, \mathrm{X}=\mathrm{I}(82 \%), \mathrm{Br}(71 \%), \mathrm{Cl}(74 \%), \mathrm{F}(58 \%)$

$\mathrm{R}^{1}=\mathrm{H}, \mathrm{Z}^{3}=\mathrm{Z}^{4}=\mathrm{CH}, \mathrm{Z}^{1}=\mathrm{Z}^{2}=\mathrm{N}, \mathrm{X}=\mathrm{I}(69 \%), \mathrm{Br}(61 \%), \mathrm{Cl}(49 \%), \mathrm{F}(65 \%)$

$\mathrm{R}^{1}=\mathrm{Ph}, \mathrm{Z}^{3}=\mathrm{CPh}, \mathrm{Z}^{1}=\mathrm{Z}^{2}=\mathrm{Z}^{4}=\mathrm{N}, X=\mathrm{Cl}(35 \%)$

$\mathrm{R}^{1}=\mathrm{F}, \mathrm{Z}^{4}=\mathrm{C}-\mathrm{I}, \mathrm{Z}^{1}=\mathrm{Z}^{2}=\mathrm{Z}^{3}=\mathrm{X}=\mathrm{F}(40 \%)$

$R^{1}=H, Z^{1}=Z^{2}=Z^{3}=Z^{4}=C H, X=I(0 \%), F(0 \%)$

$\mathrm{R}^{1}=\mathrm{H}, \mathrm{Z}^{1}=\mathrm{Z}^{2}=\mathrm{Z}^{4}=\mathrm{CH}, \mathrm{Z}^{3}=\mathrm{N}, \mathrm{X}=\mathrm{Br}(0 \%), \mathrm{Cl}(0 \%), \mathrm{F}(0 \%)$

Scheme 7. Cont. 

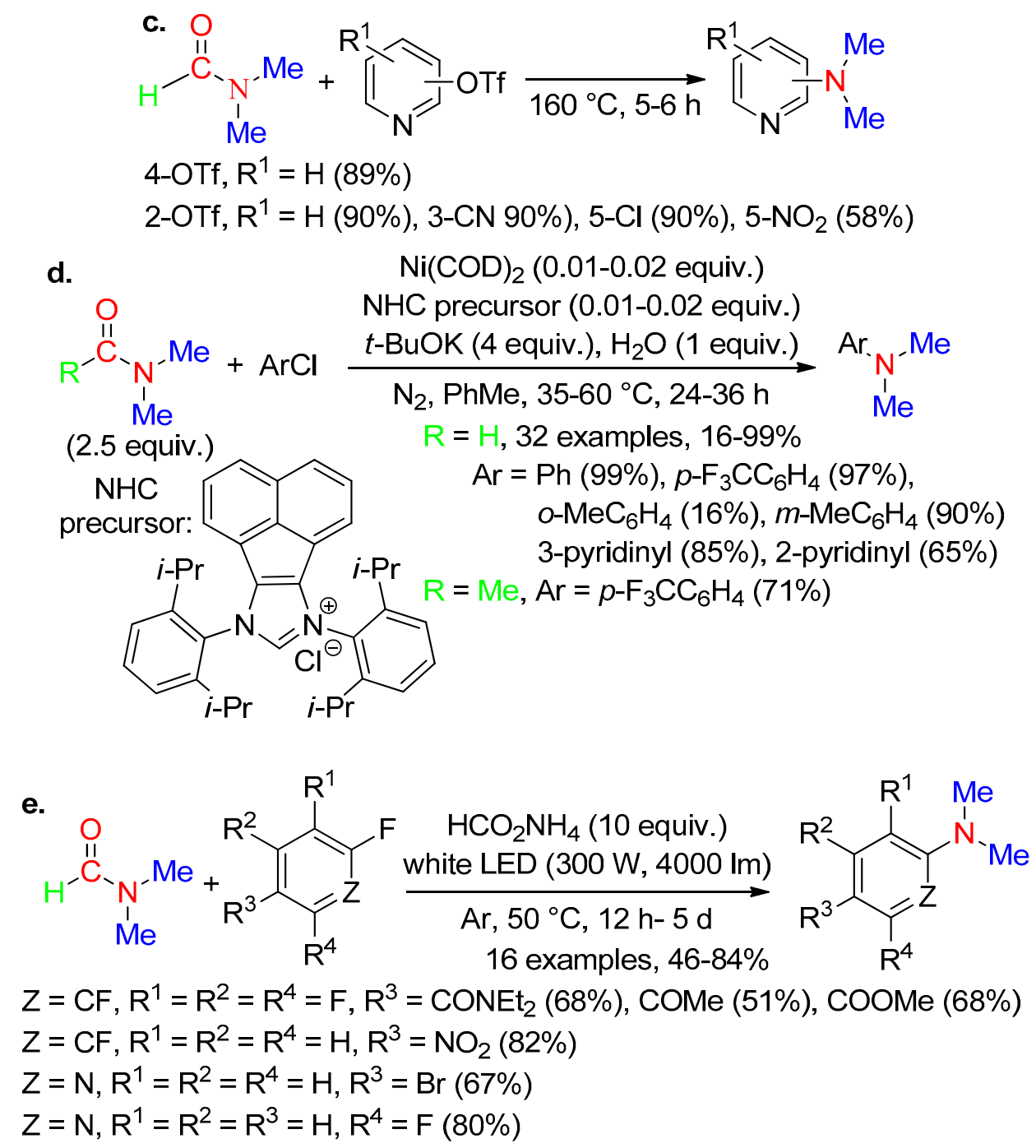

Scheme 7. Amination of (hetero)aryl halides and tosylates.

\subsection{Benzyl Ammoniums and Organochlorides}

Various $\mathrm{N}, \mathrm{N}$-dimethyl thioamides have been synthetized under aqueous conditions from DMF and quaternary (hetero)benzyl ammonium iodides (Scheme 8a) [38] or primary (hetero)benzyl/alkyl chlorides (Scheme 8b) [39] using sodium disulfide or elemental sulfur and $\mathrm{NaOH}$, respectively. The mechanism of these reactions is unclear. $\mathrm{N}, \mathrm{N}-$ Dimethylbenzothioamide was not detected using $\mathrm{N}, \mathrm{N}, \mathrm{N}$-dimethyl benzylamine instead of benzyl $N, N, N$-trimethyl ammonium iodide, and isolated in only $10 \%$ yield from the ammonium salt in the presence of a radical scavenger (Scheme 8a). According to Cheng's team, the reaction leading to $\mathrm{ArC}=\mathrm{SNR}_{3}$ involves radical cross-coupling between $\mathrm{ArC} \cdot \mathrm{HNR}_{2}$ and $\mathrm{Me}_{2} \mathrm{~N}^{\cdot}$ leading to $\mathrm{ArCH}\left(\mathrm{NR}_{2}\right)\left(\mathrm{NMe}_{2}\right)$ which evolves toward the corresponding imminium before undergoing addition of sulfur species, while Ge, Zhou, and co-workers, on the basis of controlling experiments and quantum chemical calculations, assumed a thioamidation of $\mathrm{R}^{1} \mathrm{CH}_{2} \mathrm{Cl}$ arising via the base-mediated formation of $\mathrm{R}^{1} \mathrm{C}^{\ominus} \mathrm{HCl}$ followed by addition to a $\mathrm{S}_{7}$ cluster and then reaction with DMF.

\subsection{Carbonylated Compounds}

Jiang and co-workers reported a procedure also leading to thioamides, but based on the use of alkyl or aryl aldehydes, DMF, and sodium sulfide under aqueous oxidation conditions (Scheme 9a) [40]. According to the proposed mechanism, aqueous sodium sulfide mediates the cleavage of $\mathrm{C}-\mathrm{N}$ bond providing $\mathrm{HNMe}_{2}$ and $\mathrm{H}_{2} \mathrm{~S}$. The addition of 
sulfur anion to $\mathrm{R}^{1} \mathrm{CH}=\mathrm{N}^{\oplus} \mathrm{Me}_{2}$ formed from the condensation of $\mathrm{R}^{1} \mathrm{CHO}$ with $\mathrm{HNMe}_{2}$, followed by oxidation leading to the thioamide.

a.

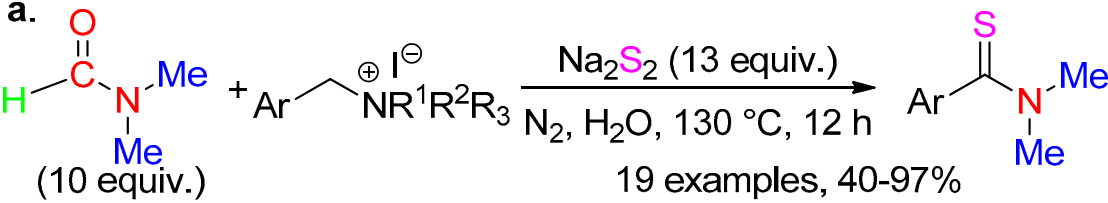

$\mathrm{R}^{1}=\mathrm{R}^{2}=\mathrm{R}^{3}=\mathrm{Me} ; \mathrm{Ar}=\mathrm{Ph}\left(85 \%^{\mathrm{a}}\right), p-\mathrm{F}_{3} \mathrm{CC}_{6} \mathrm{H}_{4}(69 \%), p-\mathrm{H}_{2} \mathrm{NC}_{6} \mathrm{H}_{4}(87 \%)$,

2-thienyl (57\%), 2-pyridinyl (73\%), 2-pyrolyl (40\%)

$\mathrm{Ar}=\mathrm{Ph}, \mathrm{R}^{1}=\mathrm{Me}, \mathrm{R}^{2}=\mathrm{Ph}, \mathrm{R}^{3}=\mathrm{Me}(91 \%)$, allyl $(70 \%)$

${ }^{a} 10 \%$ in the presence of Galvinoxyl.

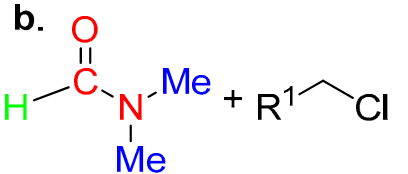

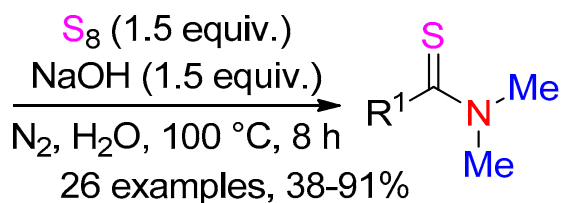

$\mathrm{R}^{1}=\mathrm{Et}(73 \%), i-\operatorname{Pr}(71 \%), \mathrm{Bn}(83 \%), \mathrm{Ph}\left(\mathrm{CH}_{2}\right)_{2}(86 \%), \mathrm{Ph}(91 \%)$,

(EtO) $)_{2} \mathrm{CH}(69 \%), m-\mathrm{FC}_{6} \mathrm{H}_{4}(70 \%), p-\mathrm{O}_{2} \mathrm{NC}_{6} \mathrm{H}_{4}(38 \%)$

3-thienyl (80\%), 2-pyridinyl (90\%), 2-benzofuranyl (70\%)

Scheme 8. Thioamidation of benzyl ammoniums and organochlorides.
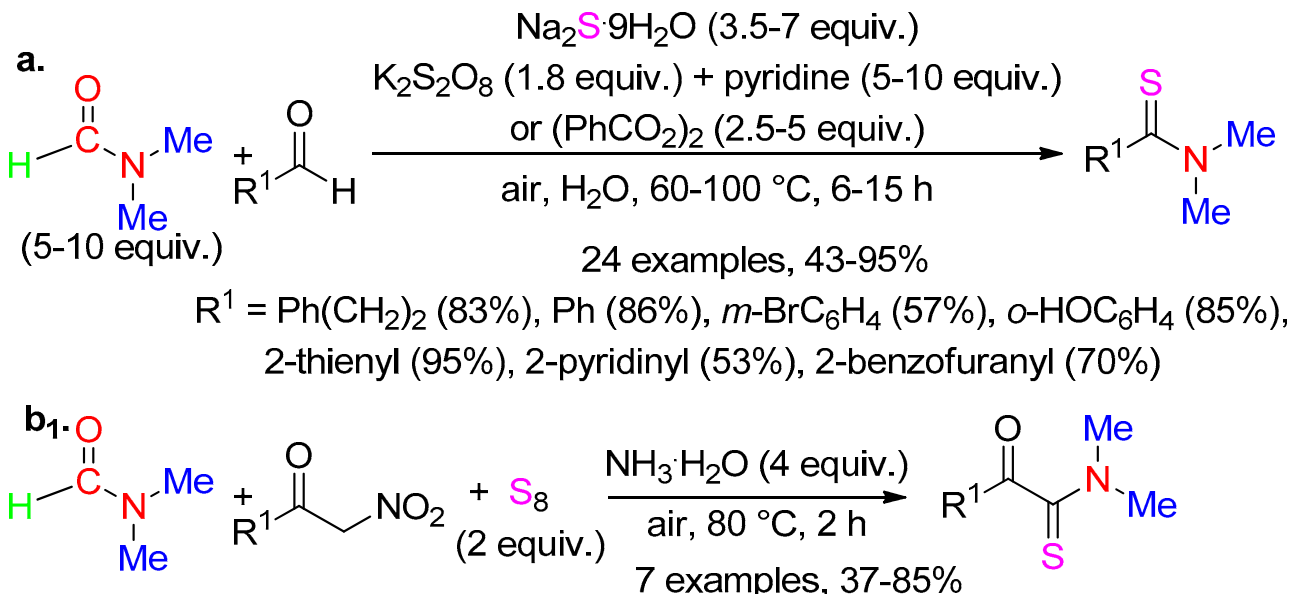

$\mathrm{R}^{1}=\mathrm{Ph}(85 \%), m-\mathrm{BrC}_{6} \mathrm{H}_{4}$ (37\%), 2-pyridinyl (72\%), 2-furyl (75\%), EtO (62\%)<smiles>[R]C(=O)C[N+](=O)[O-]</smiles><smiles>[R]C(=O)C(=S)[N+](=O)[O-]</smiles><smiles>CN(C)C(=S)C(=O)ON1CCCCC1</smiles>

Scheme 9. Thioamidation.

Denitration of nitroketones mediated with sulfur and aqueous trimethylamine in DMF provided $\alpha$-ketothioamides (Scheme $\left.9\left(b_{1}\right)\right)$ [41]. Zhang and co-workers proposed that the ketothiolation of the substrate is followed by nucleophilic attack of dimethylamine produced from decarbonylation of DMF (Scheme $9\left(b_{2}\right)$ ).

Halopyridines, especially 2,3-dibromopyridine, promote the Pd-catalyzed amidation of arylglyoxylates with DMAc (Scheme 10( $\left.a_{1}\right)$ ) [42]. The reaction occurs via Pd-catalyzed 
esterification of the carboxylate with the halopyridine followed by amidation of the resulting ester with $\mathbf{I}_{3}$ (Scheme 10( $\left.\mathrm{a}_{2}\right)$ ), the latter being issued from the addition of the in situ formed 2-bromopyridin-3-olate to DMAc.

$$
a_{1} \text {. }
$$<smiles></smiles>

$\mathrm{Pd}\left(\mathrm{OCOCF}_{3}\right)_{2}(0.05$ equiv. $)$

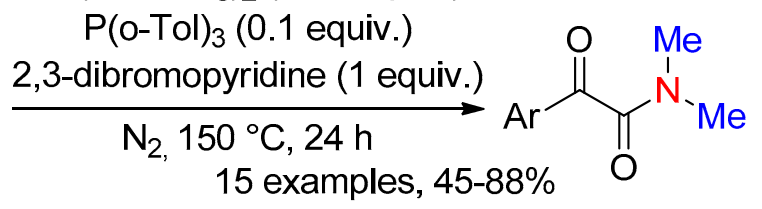

$\mathrm{Ar}=\mathrm{Ph}(71 \%), 2$-naphthyl (88\%), 2-furyl (66\%), 2-thienyl (61\%)<smiles>COCCCCCCC(=O)C(=O)Oc1cccnc1Br</smiles>

Scheme 10. Amidation of arylglyoxylates.

The Liu/Guo team disclosed the synthesis of 2-oxo-acetamidines from a mixture of methyl ketones and anilines in DMF containing peroxide, base, and $\mathrm{Cu}^{\mathrm{II}}$ catalyst under oxygen atmosphere (Scheme 11) [43]. According to control experiments, $\mathrm{R}^{1} \mathrm{COCH}_{2} \mathrm{NMe}_{2}$ produced from radical pathways involving the carbamoyl radical $\mathbf{I}_{4}$ and the aminyl radical $\mathbf{I}_{\mathbf{5}}$, is an intermediate of the reaction.

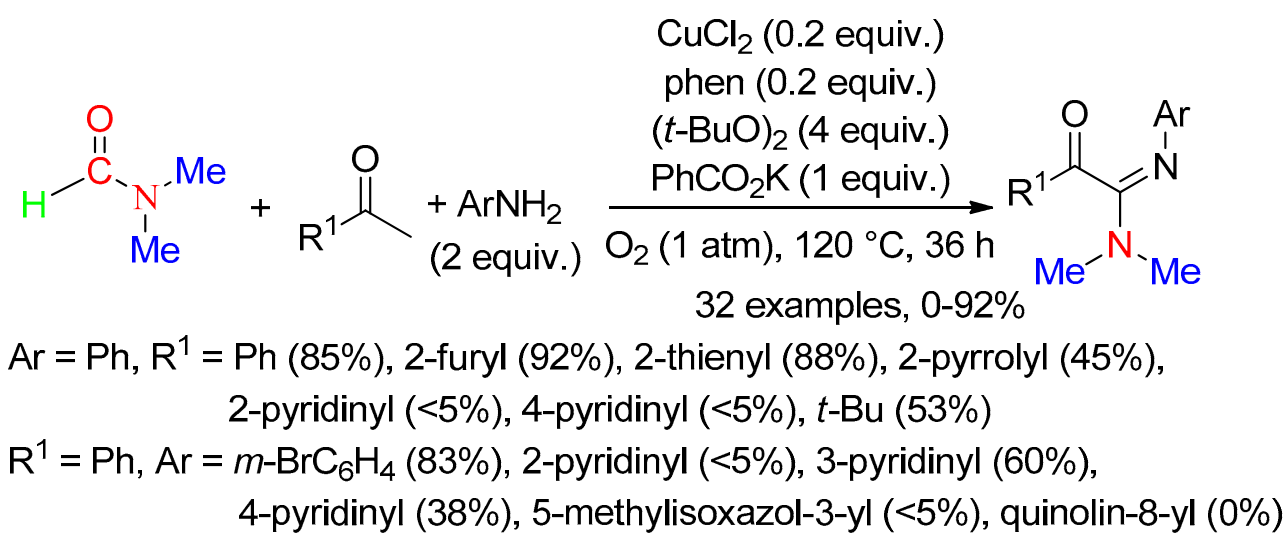

Scheme 11. Amidination of methyl ketones.

A Cu${ }^{\mathrm{I}}$-catalyzed benzannulation leading to functionalized $N, N$-dimethylnaphthalen1 -amines or $\mathrm{N}, \mathrm{N}$-dimethylquinolin-8-amine was reported under basic conditions by the Yuan/Zhou team using DM, bromo-(hetero)aryl ketones, and terminal alkynes in water (Scheme 12( $\left.a_{1}\right)$ ) [44]. One of the key steps would be the addition of $\mathbf{I}_{\mathbf{3}}$ to the alkynylCucoordinated carbonyl of the ketone (Scheme 12( $\left.a_{2}\right)$ ).

$\mathrm{N}, \mathrm{N}$-Dimethylquinolineamines have also been obtained from $\beta$-(2-aminophenyl)- $\alpha, \beta-$ ynones, DMF, and aqueous sodium hydroxide (Scheme 12b) [45].

$\mathrm{N}, \mathrm{N}$-dimethylbenzamide has been formed as a side-product of the base-promoted dehalogenation of aryl halides with PhCHO/DMF [46,47], or in 22\% yield from the treatment of benzaldehyde with $t$-BuOK at $90^{\circ} \mathrm{C}$ in DMF [46]. 


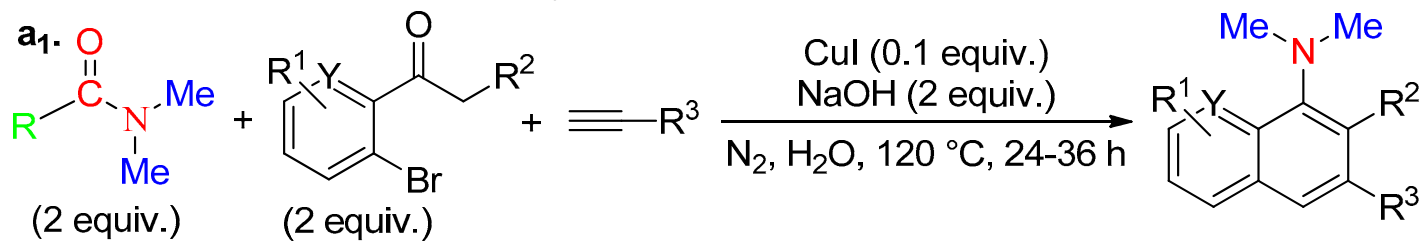

$$
\begin{aligned}
& \mathrm{R}=\mathrm{H}, \mathrm{Y}=\mathrm{CH}, \mathrm{R}^{2}=\mathrm{H}, 47 \text { examples, } 56-94 \% \\
& \mathrm{R}^{1}=\mathrm{H}, \mathrm{R}^{3}=\mathrm{Ph}(82 \%) \text {, 3-thienyl (85\%), 1-cyclohexenyl (94\%), } \mathrm{CH}_{2} \mathrm{OBn}(77 \%) \text {, } \\
& \left(\mathrm{CH}_{2}\right)_{4} \mathrm{OH}\left(80 \%{ }^{\mathrm{a}}\right),\left(\mathrm{CH}_{2}\right)_{3} \mathrm{CN}(70 \%), t-\mathrm{Bu}(83 \%) \\
& \mathrm{R}^{3}=\mathrm{Ph}, \mathrm{R}^{1}=5-\mathrm{F} \text { (86\%), 5-Br (79\%), 4-NMe } 2 \text { (78\%) } \\
& \mathrm{R}=\mathrm{H}, \mathrm{Y}=\mathrm{CH}, \mathrm{R}^{1}=\mathrm{H}, \mathrm{R}^{2}=\mathrm{Ph}, \mathrm{R}^{3}=\mathrm{Ph} \text { (trace) } \\
& \mathrm{R}=\mathrm{H}, \mathrm{Y}=\mathrm{N}, \mathrm{R}^{1}=\mathrm{H}, \mathrm{R}^{2}=\mathrm{H}, \mathrm{R}^{3}=\mathrm{Ph}(51 \%) \\
& \mathrm{R}=\mathrm{Me}, \mathrm{R}^{1}=4-\mathrm{OMe}, \mathrm{R}^{2}=\mathrm{H}, \mathrm{R}^{3}=\mathrm{Ph}(73 \%)
\end{aligned}
$$

aUsing t-BuOK (3 equiv.) in $\mathrm{H}_{2} \mathrm{O} / \mathrm{DMF}(1: 1)$.<smiles>[R]C#CC(=O)c1ccccc1Br</smiles><smiles>[R]C#C[C]OC(C)(O[Si]C)c1ccccc1Br</smiles>

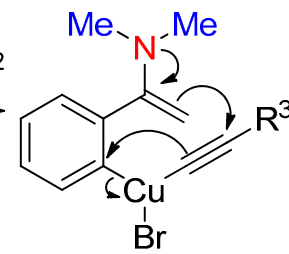<smiles>CN(C)C(=O)[18OH]</smiles><smiles>[R]C(=O)C#Cc1ccccc1N</smiles>
$\underset{\text { aqueous } \mathrm{NaOH}(2 \text { equiv.) }}{60{ }^{\circ} \mathrm{C}, 1 \mathrm{~h}}$<smiles>[R]c1cc(N(C)C)c2ccccc2n1</smiles>

$$
\mathrm{R}^{1}=\mathrm{Ph}(71 \%), 4-\mathrm{MeOC}_{6} \mathrm{H}_{4}(76 \%), n-\mathrm{C}_{5} \mathrm{H}_{11} \text { (43\%) }
$$

Scheme 12. Benzannulations.

\section{O Fragment}

In DMF, the $\mathrm{SmI}_{3} / \mathrm{CuI}$-promoted condensation of $\alpha$-halo ketones resulted in an unexpected hydroxylation reaction (Scheme 13( $\left(\mathrm{a}_{1}\right)$ ) [48]. Liu's team demonstrated that the reaction arises via a tribenzoylcyclopropane, which affords the corresponding $\alpha$-hydroxy1,4-diketone (Scheme 13( $\left.a_{2}\right)$ ) through the participation of two DMF entities (Scheme 13( $\left.a_{3}\right)$ ).

Zoidis and co-workers revealed a competing transesterification in the course of $\mathrm{N}$ alkylation of $\mathrm{N}$-(benzoxycarbonylmethyl)hydantoins with ethyl iodide and sodium hydride in DMF (Scheme 14a) [49]. According to the authors, the reaction occurs via attack of the DMF-zwitterionic mesomer $\mathbf{I}_{6}$ on EtI, yielding the ammonium salt $\mathrm{Me}_{2} \mathrm{~N}^{\oplus}=\mathrm{CHOEt}$ which suffers from the addition of hydride leading to $\mathrm{Me}_{2} \mathrm{NCH}(\mathrm{OEt}) \mathrm{H}$. Dissociation of the latter gives $\mathrm{EtO}^{\ominus}$ which undergoes an $\mathrm{S}_{\mathrm{N}} 2$ reaction with the benzyl ester.

Catalysis with silyl-molybdenum complexes of the polymerization of dihydroorganosilanes in DMF led to the participation of the DMF-oxygen atom affording polysiloxanes (Scheme 14b) [50]. 


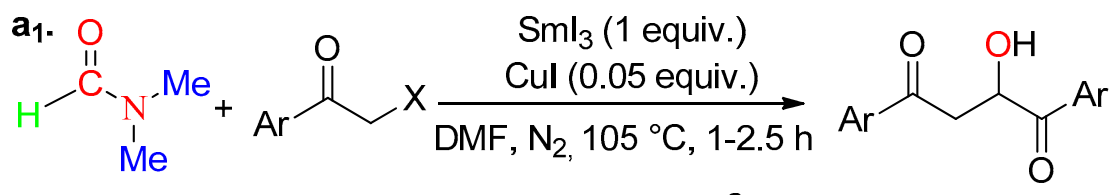

$$
\begin{aligned}
& \mathrm{X}=\mathrm{Br}, 7 \text { examples }(0-72 \%), \mathrm{Ar}=\mathrm{Ph}\left(71 \%^{\mathrm{a}}\right), p-\mathrm{PhC}_{6} \mathrm{H}_{4}(0 \%) \\
& \mathrm{X}=\mathrm{Cl}, 7 \text { examples }(60-78 \%), \mathrm{Ar}=\mathrm{Ph}(66 \%) \\
& \mathrm{X}=\mathrm{I}, 1 \text { example, } \mathrm{Ar}=\mathrm{Ph}(77 \%) \\
& { }^{a} \text { In THF instead of DMF: formation of }\left(\mathrm{PhCOCH}_{2}\right)_{2}(73 \%) \text {. }
\end{aligned}
$$
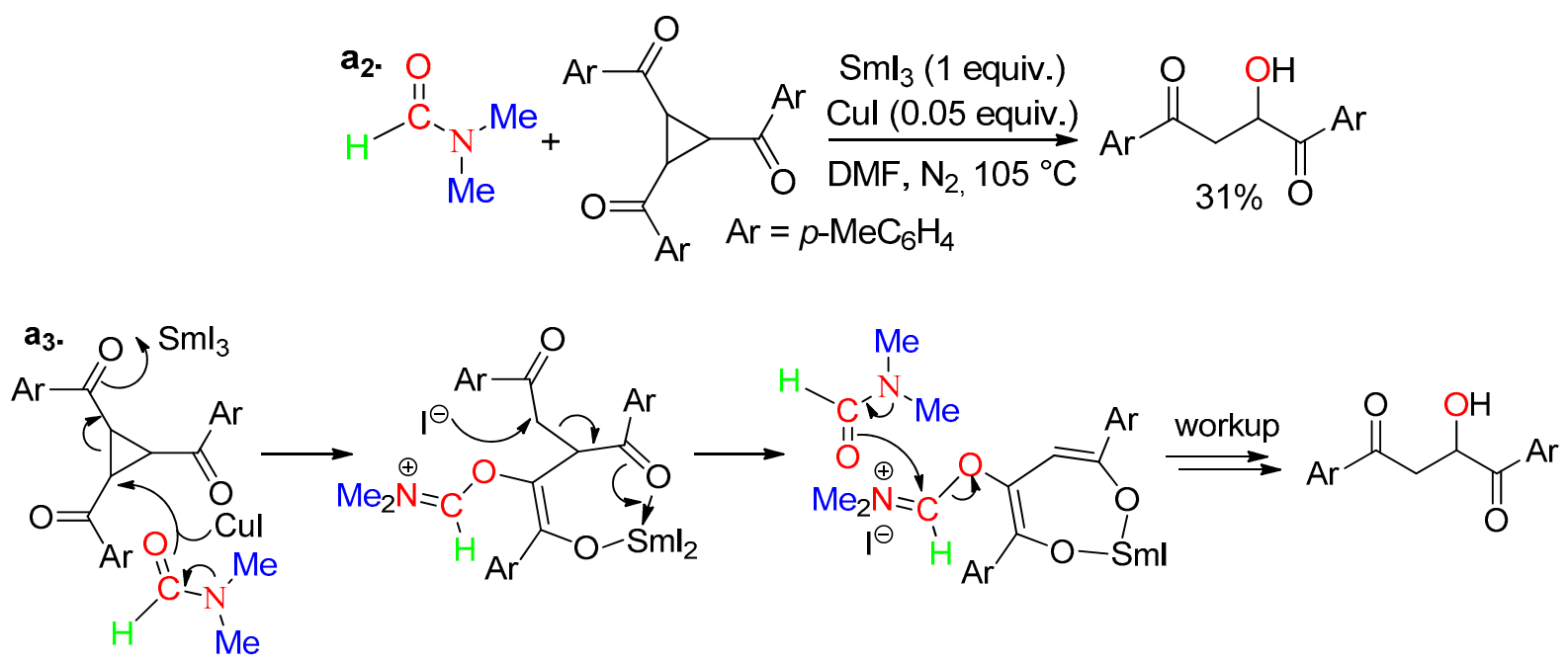

Scheme 13. Hydroxylation reaction.
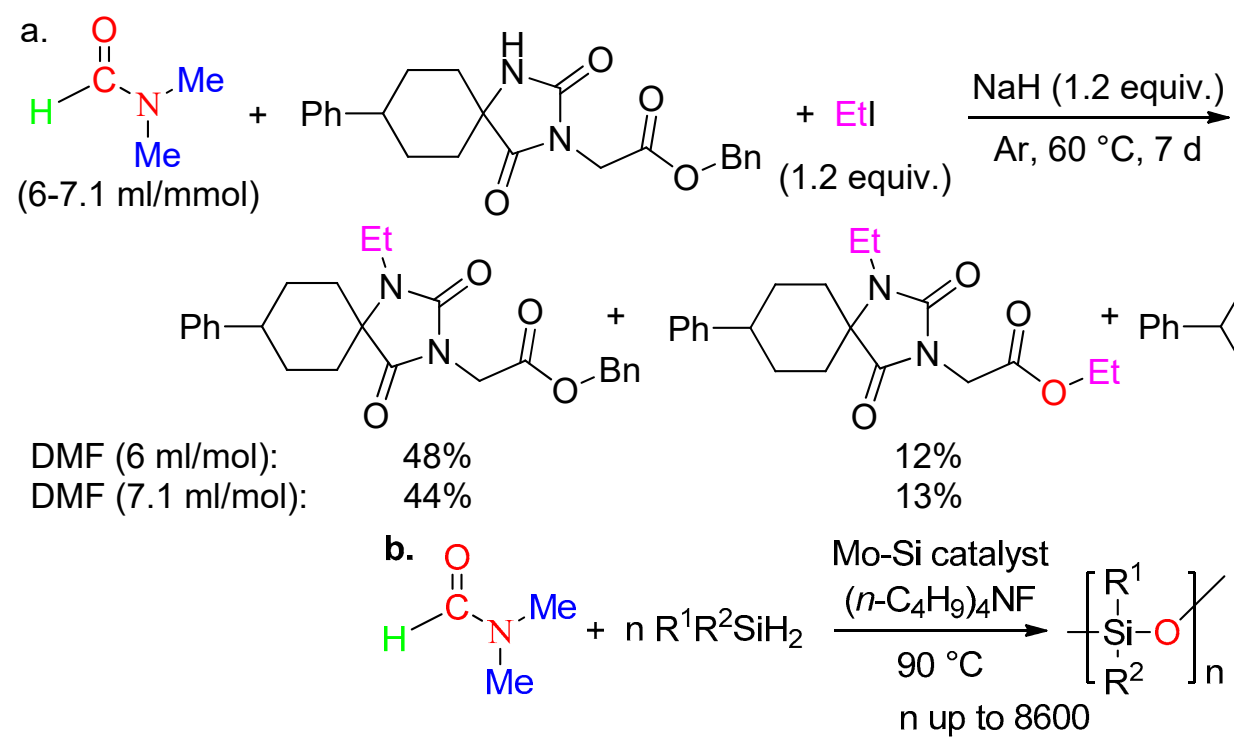

Scheme 14. Oxygen insertion.

\section{CO Fragment}

A recent review summarizes carbonylations using diverse $\mathrm{CO}$ surrogates including DMF [51].

The use of DMF as the solvent has favored carbonylations with oxalic acid [52], $\mathrm{Mo}(\mathrm{CO})_{6}[53,54]$, or formylpyrrolidine [55] as the CO source, or carbon monoxide pressure [56]. 
DM was not the $\mathrm{CO}$ source of the amide functionality obtained from Pd-catalyzed hydrocarbonylation of alkenes in DM under $\mathrm{CO}$ pressure, only the $\mathrm{NMe}_{2}$ moiety was involved [3,57]. To the best of our knowledge, no new report concerns the carbonylation reaction using the $\mathrm{CO}$ fragment of $\mathrm{DM}$.

\section{9. $\mathrm{CONMe}_{2}$ Fragment}

Examples leading to side compounds containing the $\mathrm{CONMe}_{2}$ fragment are included in Section 15.

In DMF, ligation to $\mathrm{CrCl}_{2}$ of the tripeptide formed from 2-amino-2-methylpropanoic acid followed by oxidation afforded the anionic urea $\mathrm{Cr}^{\mathrm{V}}$ complex depicted in Scheme 15 [58].

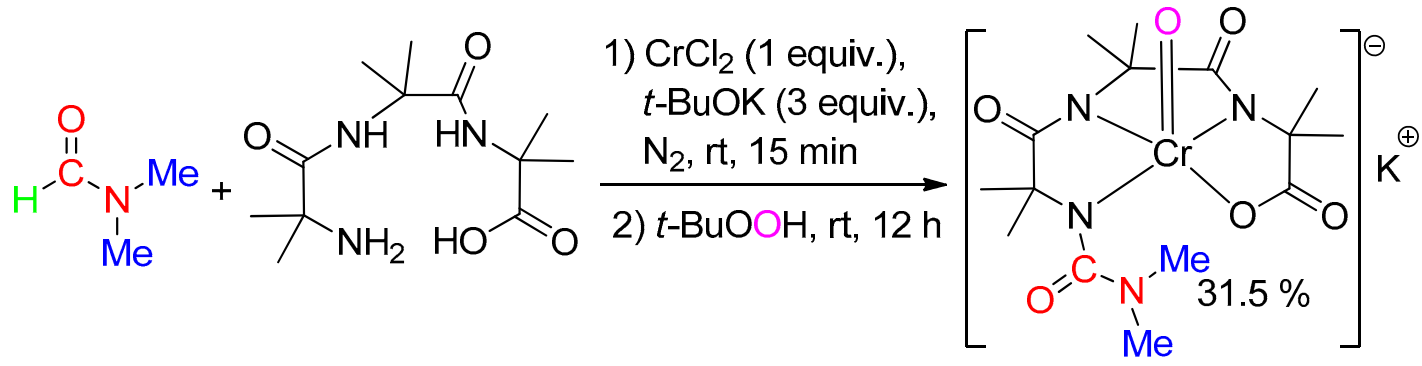

Scheme 15. Formation of a 3,3-dimethylurea derivative.

The oxidation in DMF of benzyl alcohol, benzaldehyde, benzoic acid, styrene, phenyl acetylene, and corresponding $p$-substituted substrates using a mesoporous copper catalyst named HKUST-1-Cu led to cleavage of the Ar-function bond giving $N, N$-dimethylarylamides (Scheme 16) [59].

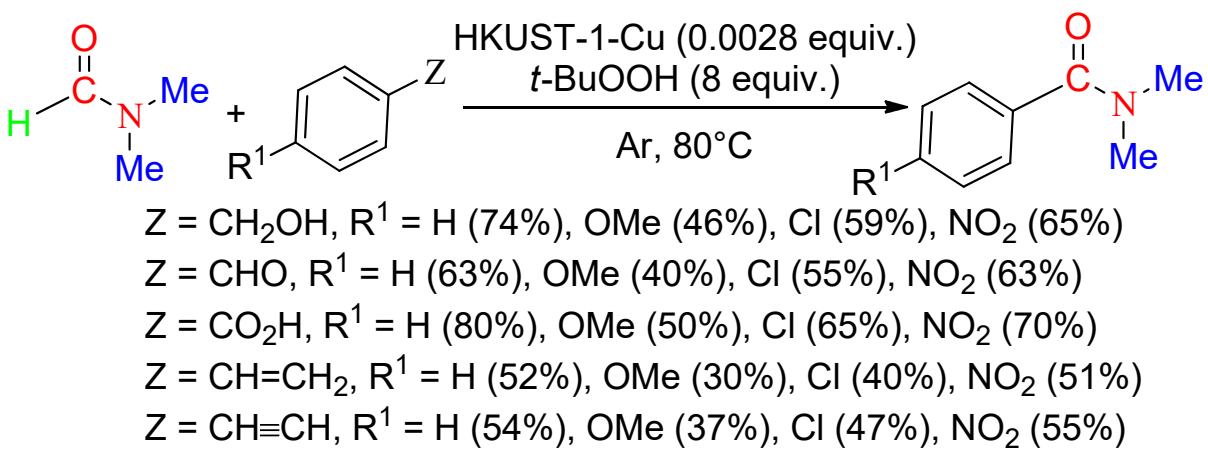

Scheme 16. Oxidative cleavage of functionalized arenes.

The carbamoylation of the double bond of enamides and styrenes with DMF arose under oxidative conditions mediated with $\mathrm{Fe}$ catalysis at $65-80^{\circ} \mathrm{C}$ (Scheme 17a) [60] or visible light at room temperature (Scheme 17b) [61], respectively. Refluxing 1,1-diphenylethylene in DMF with di-tert-butyl peroxide led to a low yield of $N, N$-dimethyl-3,3-diphenylacrylamide even under $\mathrm{Cu}$ catalysis (Scheme 17c) [62].

In the presence of peroxides, the reaction of $\beta$-dicarbonyl compounds with DMF under catalysis with either a copper supported Mg-Al hydrotalcite derived oxide (Scheme 18a) [63] or a maghemite-copper oxide nanocomposite (Scheme 18b) [64]afforded enol carbamates, while a soluble catalyst- $\mathrm{Cu}(\mathrm{OTf})_{2}$ - gave, according to Zou's team, 2-carbamoyl-1,3dicarbonyl compounds (Scheme 18c) [62]. Given the NMR chemical shifts attributed to the latter, especially those of the putative 2-benzoyl- $\mathrm{N}, \mathrm{N}$-dimethyl-3-oxo-3-phenylpropanamide, the right structure is not obvious and remains an open question. Mail sent to J.-P. Zou remained without an answer. 

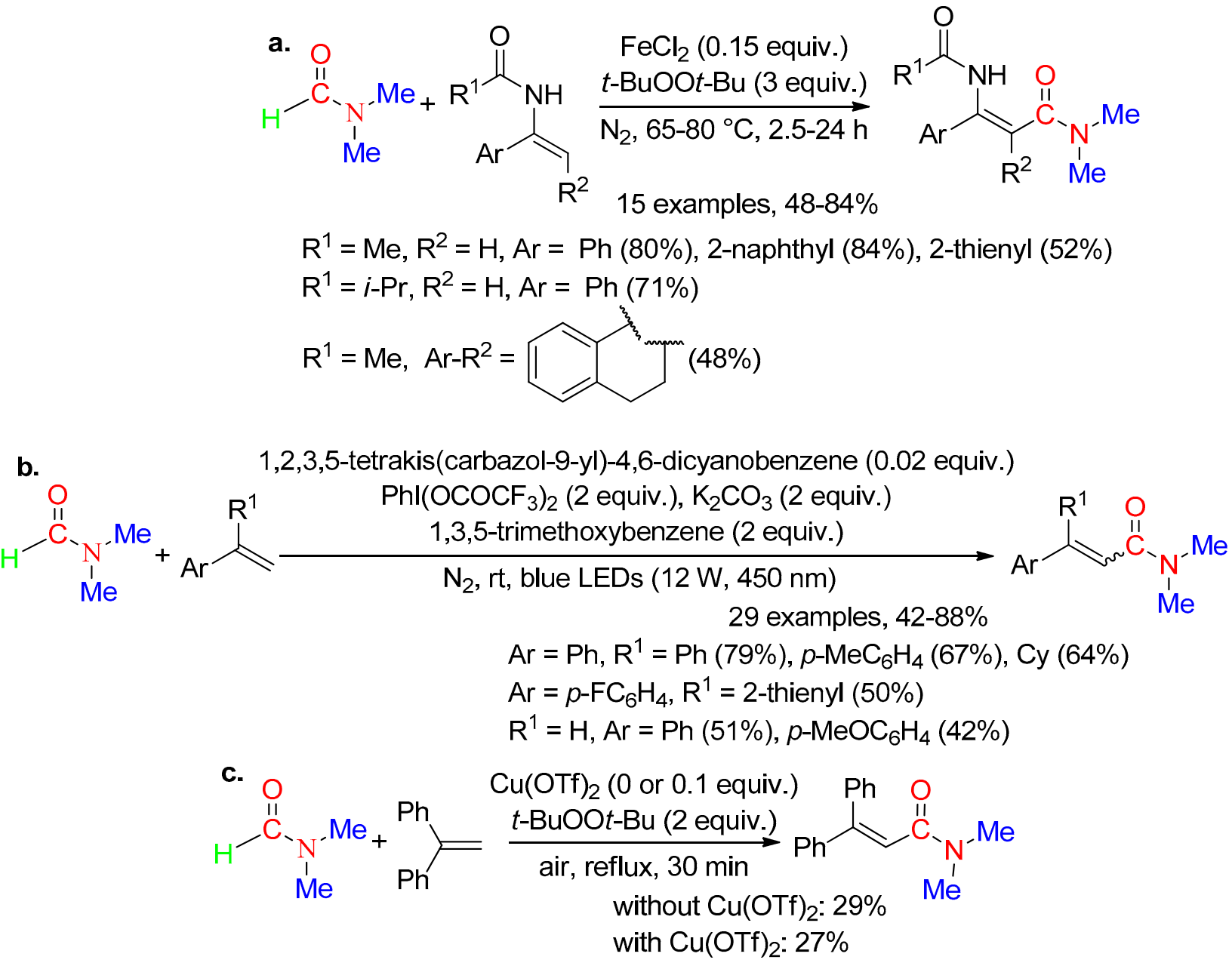

Scheme 17. Carbamoylation of activated double bonds.

Mao, Zhang, and co-workers reported the thiolation of the $\mathrm{C}-\mathrm{H}$ bond of DMF using di-tert-butyl peroxide and either 1,2-di-p-tolyldisulfane (Scheme 19( $\left.\mathrm{a}_{1}\right)$ ) or arylsulfonyl hydrazides and aluminum chloride (Scheme 19( $\left.\mathrm{a}_{2}\right)$ ) [65], while Bi, Feng, Geng, and coworkers recently used tert-butyl hydroperoxide and $S$-aryl arenethiosulfonates under visible-light irradiation (Scheme 19b) [66]. This last procedure is, however, ineffective for DMF thiolation with 1,2-di-p-phenyldisulfane [66]. According to the authors [65,66], these reactions involve the radical $\mathbf{I}_{4}$. Jia's team, in the course of the study of functionalization of styrenes with thiosulfonates and arylboronic acids in acetone/DMF, also proposed that $S$-methyl dimethylcarbamothioate isolated as a by-product was formed from the reaction of $S$-methyl 4-methylbenzenesulfonothioate with $\mathbf{I}_{4}$ (Scheme 19c) [67].

Thiocarbamation of 2-arylimidazo[1,2-a]pyridines with elemental sulfur and DMF has been carried out with di-tert-butyl peroxide and $\mathrm{Cu}$ catalysis at $120{ }^{\circ} \mathrm{C}$ [68]. The reaction was promoted with $\mathrm{N}$-bromosuccinimide (Scheme 20(a $\left.\mathrm{a}_{1}\right)$ ) and also occurred using 6-phenylimidazo[2,1-b]thiazole as the substrate (Scheme 20( $\left.\left.a_{2}\right)\right)$. The Cui/Tang team proposed a radical mechanism with $\mathbf{I}_{4}$ reacting with sulfur leading to $\mathrm{Me}_{2} \mathrm{NCOS}$, and possibly also NBS giving $\mathrm{Me}_{2} \mathrm{NCOSBr}$. Both species could react with the substrate to deliver the isolated product. 


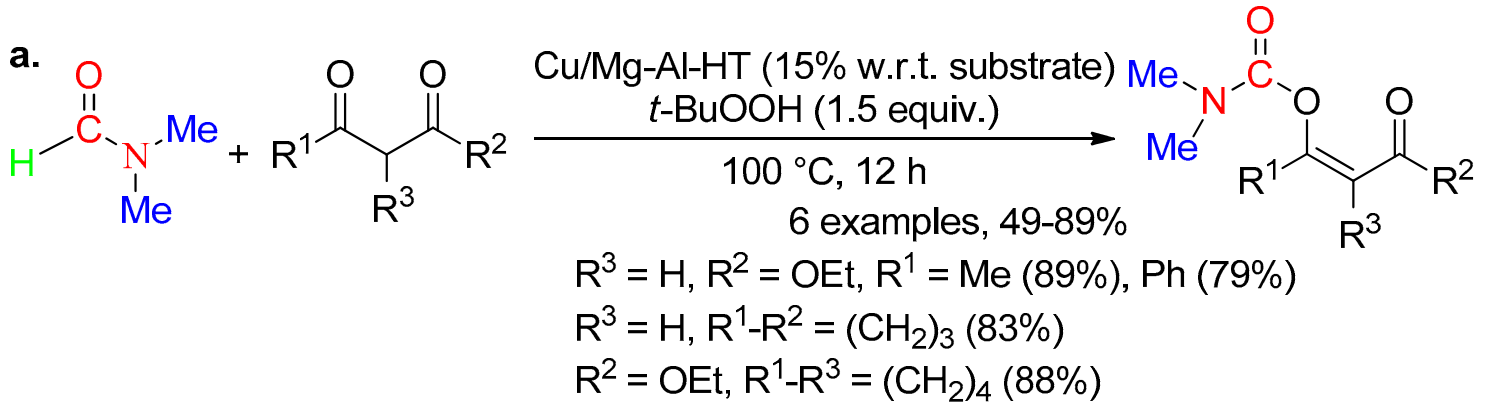

b.

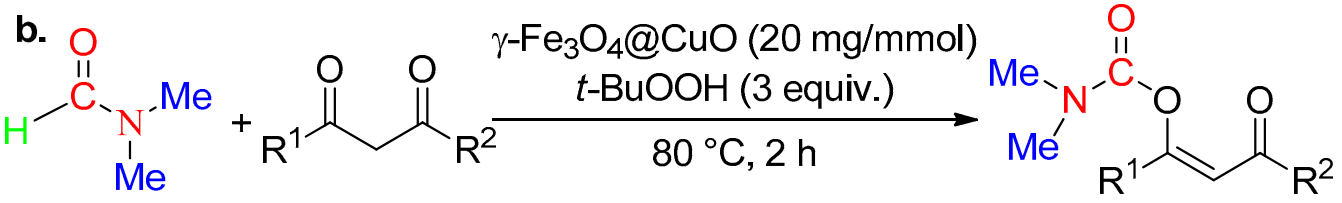

$\beta$-Ketoester: 6 examples, 84-92\% $\mathrm{R}^{1}=\mathrm{Me}, \mathrm{R}^{2}=\mathrm{OEt}(90 \%), \mathrm{Ot}-\mathrm{Bu}(88 \%)$, Oallyl (87\%)

$\beta$-Diketone: 4 examples, $80-88 \%$

$$
\begin{aligned}
& R^{1}=M e, R^{2}=P h(88 \%), \operatorname{Me}(82 \%) \\
& R^{1}-R^{2}=\left(\mathrm{CH}_{2}\right)_{3}(82 \%)
\end{aligned}
$$

c.

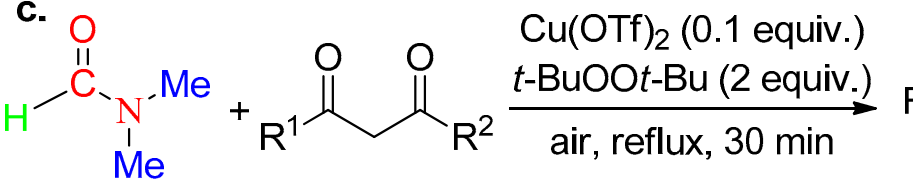

$\beta$-Diketone: 16 examples, 40-93\%

$$
\begin{aligned}
& \mathrm{R}^{1}=\mathrm{R}^{2}=\mathrm{Ph}(93 \%), \mathrm{Me}(40 \%), \mathrm{Et}(90 \%), t-\mathrm{Bu}(90 \%) \\
& \mathrm{R}^{1}=\mathrm{Ph}, \mathrm{R}^{2}=\mathrm{Et}(92 \%), 4-\mathrm{MeC}_{6} \mathrm{H}_{4}(87 \%) \\
& \mathrm{R}^{1}-\mathrm{R}^{2}=\mathrm{CH}_{2} \mathrm{CMe}_{2} \mathrm{CH}_{2}(62 \%)
\end{aligned}
$$

$\beta$-Ketoester: $\mathrm{R}^{2}=\mathrm{OEt}, 10$ examples, $65-94 \%$ $\mathrm{R}^{1}=\mathrm{Ph}(93 \%), 4-\mathrm{MeC}_{6} \mathrm{H}_{4}(82 \%), 4-\mathrm{O}_{2} \mathrm{NC}_{6} \mathrm{H}_{4}$ (65\%), Et (93\%)

$\beta$-Diester: $R^{1}=R^{2}=$ OEt $(65 \%)$

Scheme 18. O- or C-carbamates from $\beta$-dicarbonyl compounds.<smiles>Cc1ccc(SSc2ccc(C)c([C+](C)(C)OCC(C)(C)C)c2)cc1</smiles><smiles>[R1][R14]1cccc(S(=O)(=O)NN)c1</smiles>
12 examples, $35-65 \%$

$\mathrm{R}^{1}=\mathrm{H}(63 \%), o-\mathrm{Me}(49 \%), p-\mathrm{Me}(65 \%), p-\mathrm{Br}(61 \%), p-\mathrm{CF}_{3}(35 \%)$ 


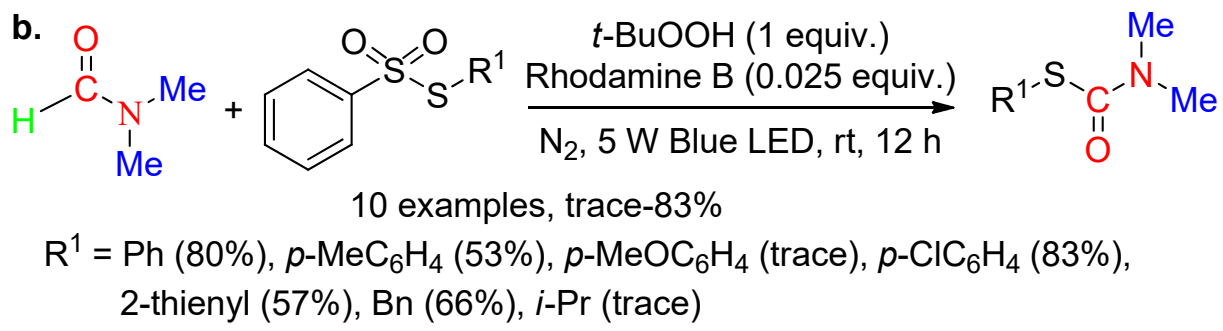<smiles>CSS(=O)(=O)c1ccc(C)cc1</smiles>

Scheme 19. Thiolation of DMF.

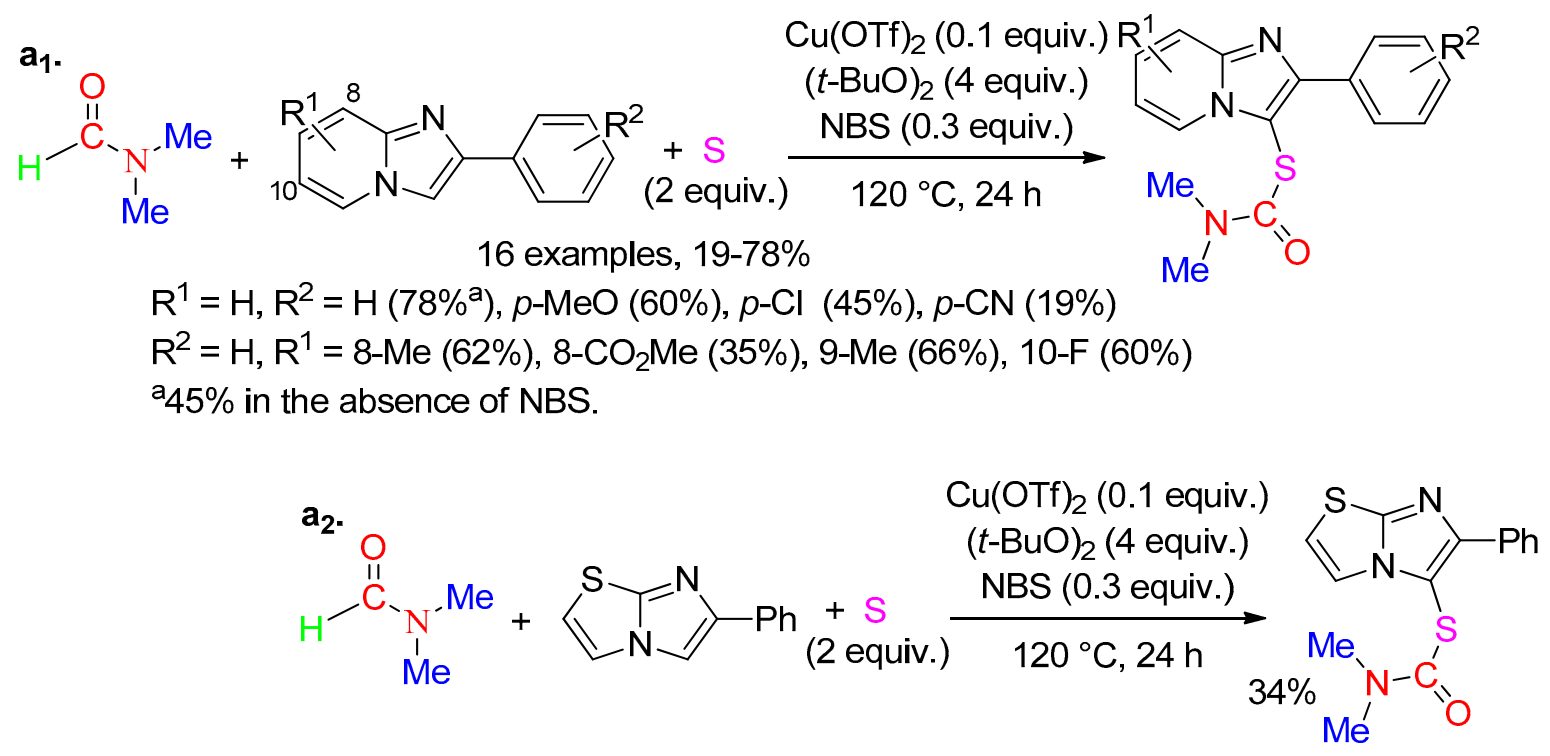

Scheme 20. Thiocarbamation of heterocycles.

All the above processes of this section involve the participation of radical $\mathbf{I}_{\mathbf{4}}$ formed by catalyst/peroxide-mediated homolytic cleavage of DMF.

Hexafluorophosphate benzotriazole tetramethyl uronium (HBTU) is a peptide coupling reagent frequently used [69-71]. An impurity with an abundance of $0.09 \%$ was detected by Badalassi and co-workers in the Peptide Q API solution obtained from the HBTU-mediated Peptide Q cyclization in DMF [72]. This impurity was identified as being $1 H$-benzo[d][1-3]triazol-1-yl dimethylcarbamate formed from the addition of DMF to HBTU as depicted in Scheme 21.

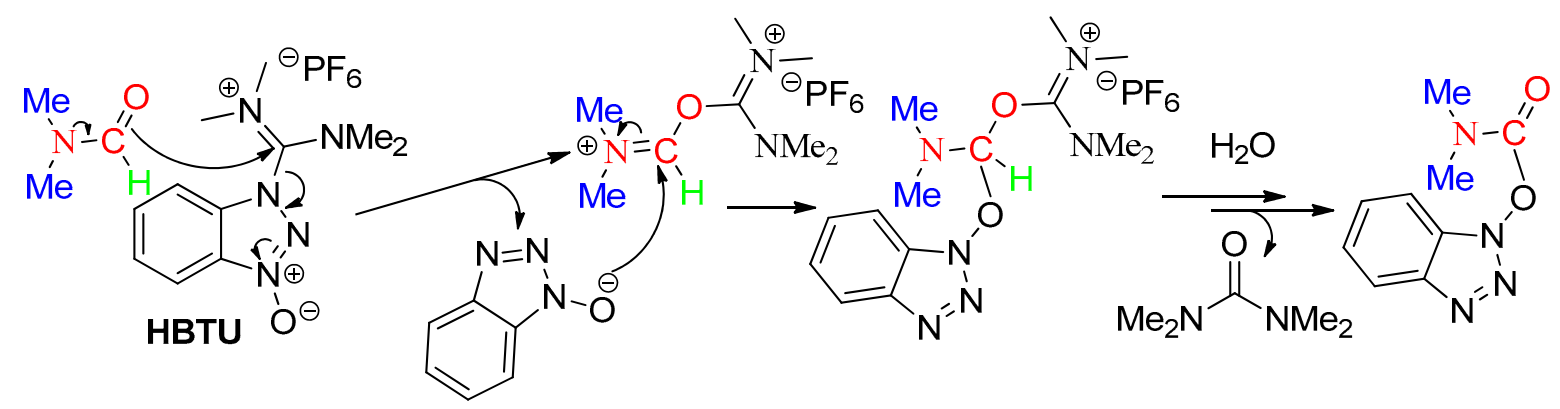

Scheme 21. HBTU degradation. 


\section{H Fragment}

The chemoselective reduction of $\alpha$-ketoamides arose from treatment with sodium hydroxide and water in DMF (Scheme 22) [73]. Deuterium labeling experiments led Wu and co-workers to assume hydride delivery from HCOONa produced from the hydrolysis of DMF with hydrated $\mathrm{NaOH}$.

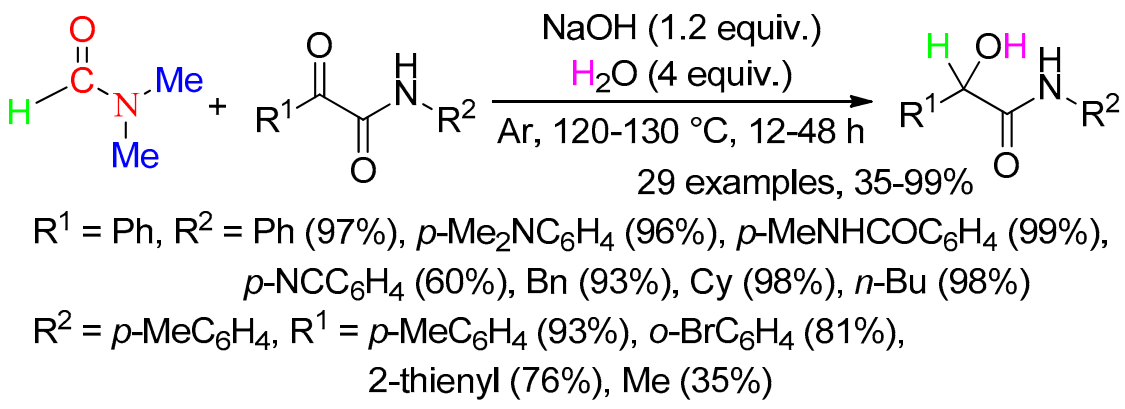

Scheme 22. Hydride transfer.

The association of $t$-BuOK, DMF, and visible-light irradiation mediated the dehalogenation of (hetero)aryl fluorides, chlorides, bromides, and iodides (Scheme 23a) [74], while the reductive cleavage of 4-methoxybenzenediazonium tetrafluoroborate occurred under light-free conditions (Scheme 23b) [75]. According to Qu/Kang's and Taillefer's teams $[74,75]$, these reactions implicate the carbamoyl anion $\mathbf{I}_{\mathbf{7}}$ and, via electron transfer, the carbamoyl radical $\mathbf{I}_{4}$. Such a reactivity of DMF under $t$-BuOK conditions has been exploited for transition-metal-free Matsuda-Heck type reactions [75].

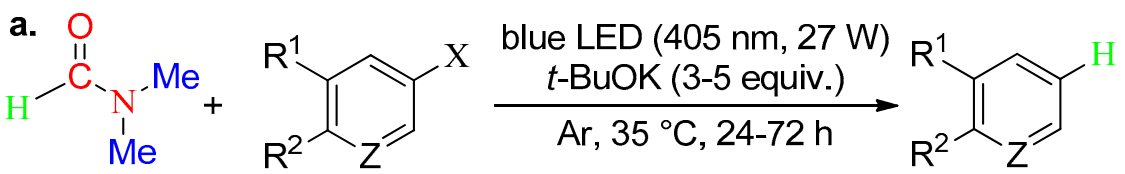

$\mathrm{X}=\mathrm{Cl}, 28$ examples, $47-100 \%$

$$
\begin{aligned}
& Z=C H, R^{1}=H, R^{2}=C N(100 \%), \operatorname{PhCO}(51 \%) \\
& Z=N, R^{1}-R^{2}=(C H)_{4}(47 \%)
\end{aligned}
$$

$\mathrm{X}=\mathrm{F}, \mathrm{Z}=\mathrm{CH}, 8$ examples, $50-88 \%$

$\mathrm{R}^{1}=\mathrm{H}, \mathrm{R}^{2}=\mathrm{Ph}(81 \%)$

$\mathrm{X}=\mathrm{Br}, \mathrm{Z}=\mathrm{CH}, 7$ examples, $58-100 \%$

$\mathrm{R}^{1}=\mathrm{H}, \mathrm{R}^{2}=\mathrm{H}(82 \%), \mathrm{Ph}(74 \%), \mathrm{OMe}(100 \%)$

$X=I, Z=C H, 11$ examples, $63-100 \%$

$\mathrm{R}^{1}=\mathrm{H}, \mathrm{R}^{2}=\mathrm{H}(100 \%)$, Et (91\%), OH (96\%)

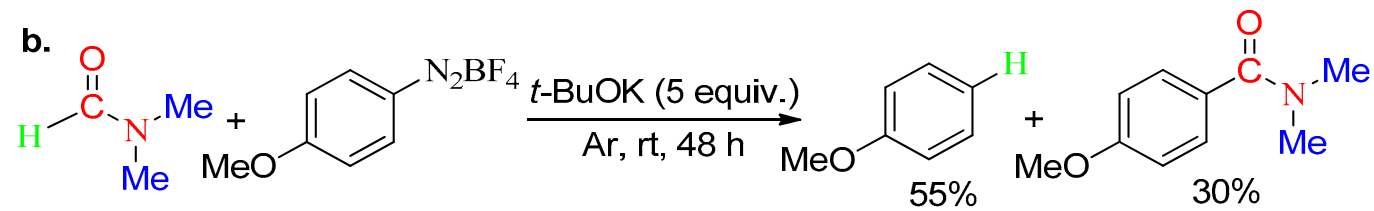

Scheme 23. Radical reactions.

\section{RC Fragment}

Heterocycles containing the CR fragment have been synthetized from a variety of amino substrates (Scheme 24) [76-79]. Under the experimental conditions of Scheme 24a, activation of the carbonyl group of DMF by HMDS favors the nucleophilic addition of the arylamine leading to an intermediate that undergoes internal addition of the other nucleophilic moiety of the substrate. In the presence of imidazolium chloride (Scheme $24 \mathrm{~b}-\mathrm{d}$ ), 
the addition of imidazole to $\mathrm{HCl}$-activated carbonyl of DM leads to $\mathrm{C}_{3} \mathrm{H}_{3} \mathrm{~N}_{2} \mathrm{COR}$ which undergoes nucleophilic addition with the substrate.

Using both $t$-BuONa and amine-borane in DM, Y.-F., Wang, and co-workers carried out the $C$-methylation or $C$-ethylation of $\mathrm{N}, \mathrm{N}$-dimethyl-2-phenylacetamide and various arylacetonitriles in fair to high yields while the reaction of ethyl 2-phenylacetate was much less efficient (Scheme 25a) [80]. One year later, in collaboration with the team of Z. Wang, they disclosed the methylenation of 2-arylacetamides under similar conditions (Scheme 26) [81]. Another year later, they reported the $\mathrm{N}$-monomethylation and $\mathrm{N}$-monoethylation of primary anilines with the $\mathrm{NaH} / \mathrm{Me}_{2} \mathrm{NH}-\mathrm{BH}_{3} / \mathrm{DM}$ association (Scheme 25b) [82]. Interestingly, the use of DMF or $d_{7}-\mathrm{DMF}$ with $\mathrm{Me}_{2} \mathrm{NH}-\mathrm{BH}_{3}$ and $\mathrm{Me}_{2} \mathrm{NH}-\mathrm{BD}_{3}$ allowed the controllable installation of $\mathrm{N}-\mathrm{CH}_{2} \mathrm{D}, \mathrm{N}-\mathrm{CHD}_{2}$, and $\mathrm{N}-\mathrm{CD}_{3}$ units [82]. The proposed $\mathrm{N}$-methylation mechanism of anilines includes deprotonation of $\mathrm{ArNH}_{2}$ mediating addition to DM leading to anionic species ArNHCRO ${ }^{\ominus} \mathrm{NMe}_{2}$ which evolves toward $\mathrm{ArN}=\mathrm{CRNMe}$. The ensuing reduction with $\mathrm{Me}_{2} \mathrm{NH}-\mathrm{BH}_{3}$ provides ArNHCHRNMe 2 [82]. The base-promoted elimination of $\mathrm{HNMe}_{2}$ gives $\mathrm{ArN}=\mathrm{CHR}$ which undergoes reduction leading to $\mathrm{ArNH}\left(\mathrm{CH}_{2} \mathrm{R}\right)$.

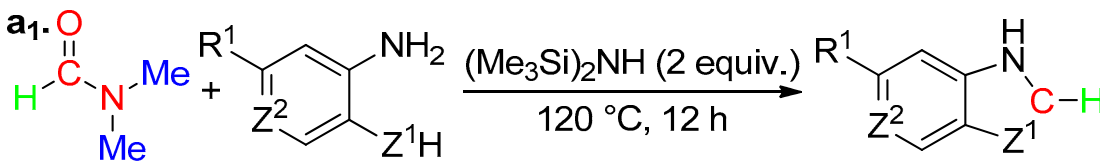

$$
\begin{aligned}
& Z^{1}=N, Z^{2}=C H, R^{1}=H(97 \%), M e(87 \%), N_{2}(68 \%) \\
& Z^{1}=N, Z^{2}=N, R^{1}=H(45 \%) \\
& \mathrm{Z}^{1}=\mathrm{S}, \mathrm{Z}^{2}=\mathrm{CH}, \mathrm{R}^{1}=\mathrm{H}(90 \%) \\
& \mathrm{Z}^{1}=\mathrm{O}, \mathrm{Z}^{2}=\mathrm{CH}, \mathrm{R}^{1}=\mathrm{H}(0 \%)
\end{aligned}
$$

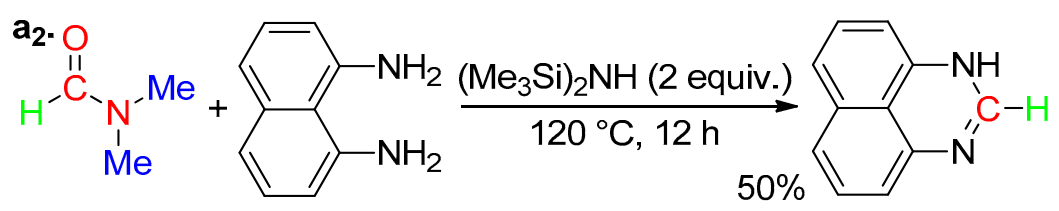

b.

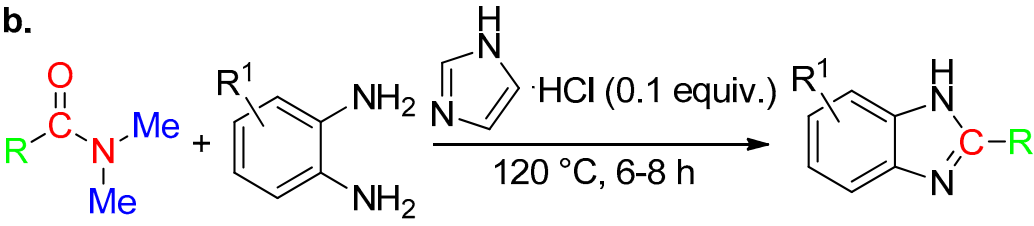

$$
\begin{aligned}
\mathrm{R}=\mathrm{H}, 10 \text { examples, } 82-94 \% \\
\quad \mathrm{R}^{1}=\mathrm{H}(94 \%), 6-\mathrm{Cl}(85 \%), 6-\mathrm{CF}_{3}(82 \%)
\end{aligned}
$$$$
\mathrm{R}=\mathrm{Me}, 6 \text { examples, } 65-84 \%
$$$$
\left.\mathrm{R}^{1}=\mathrm{H}(84 \%), 6-\mathrm{Cl}(75 \%), 6-\mathrm{NO}_{2} 65 \%\right)
$$

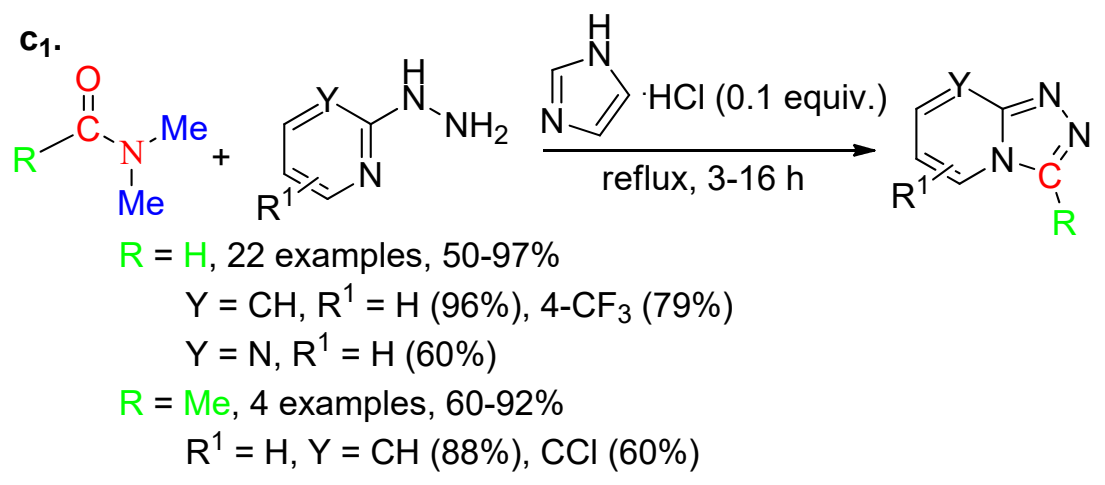

Scheme 24. Cont. 

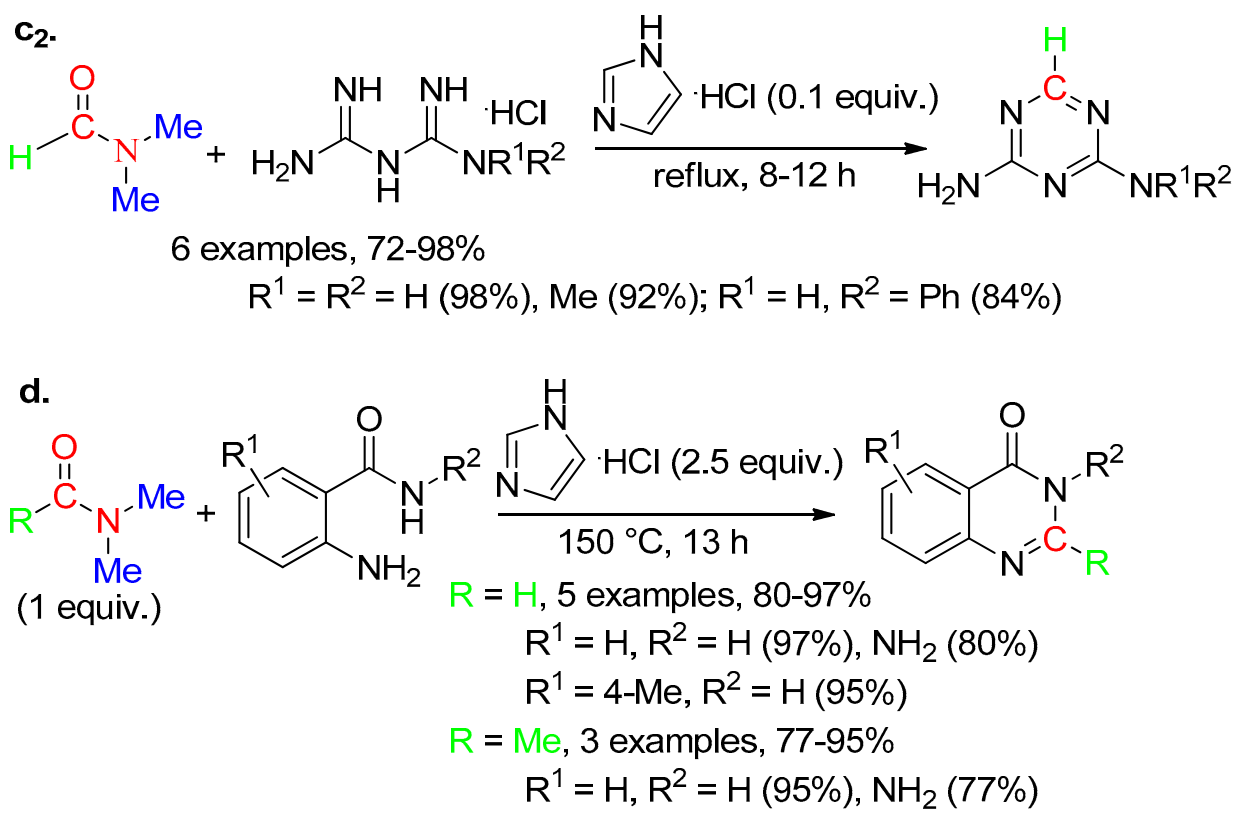

Scheme 24. Heterocyclization involving CR.

a.<smiles>[R]C(=O)N(C)C</smiles>
$\mathrm{Me}_{2} \mathrm{NH}-\mathrm{BH}_{3}$ (1 equiv.) $t$-BuONa (1.5-3 equiv.)

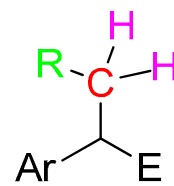

$\mathrm{R}=\mathrm{H}, \mathrm{E}=\mathrm{CN}: 23$ examples, 48-98\% $\mathrm{Ar}=\mathrm{Ph}$ (73\%), 2-naphthyl (92\%), 3-benzothiophenyl (48\%), 3-pyridinyl (67\%), 3-(N-methyl)indolyl (64\%)

$\mathrm{R}=\mathrm{H}, \mathrm{E}=\mathrm{CONMe}_{2}{ }^{\mathrm{a}}, \mathrm{Ar}=\mathrm{Ph}(68 \%)$

$\mathrm{R}=\mathrm{H}, \mathrm{E}=\mathrm{CO}_{2} \mathrm{Et}, \mathrm{Ar}=\mathrm{Ph}(8 \%)^{\mathrm{b}}$

$\mathrm{R}=\mathrm{Me}, \mathrm{E}=\mathrm{CN}^{\mathrm{C}}, \mathrm{Ar}=$ 2-naphthyl $(68 \%)$

${ }^{a}$ At $120{ }^{\circ} \mathrm{C}$ for $11 \mathrm{~h}$ using $t$-BuOK (3 equiv.) and $\mathrm{Me}_{2} \mathrm{NH}-\mathrm{BH}_{3}$ (2.5 equiv.) ${ }^{b}$ Plus phenylacetic acid (70\%)

${ }^{\mathrm{C}}$ At $120{ }^{\circ} \mathrm{C}$ for $20 \mathrm{~h}, 72 \%$ conversion.

b.<smiles>[R]C(=O)N(C)[14CH2]N</smiles>

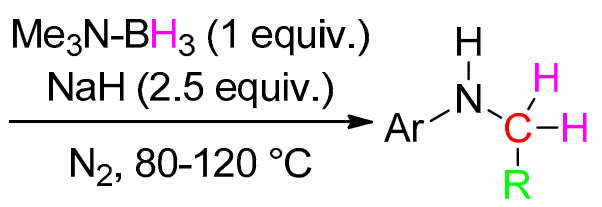

$\mathrm{R}=\mathrm{H}, 80^{\circ} \mathrm{C}, 1-24 \mathrm{~h}, 29$ examples, 0-91\% $\mathrm{Ar}=p-\mathrm{ClC}_{6} \mathrm{H}_{4}(91 \%), m-\mathrm{ClC}_{6} \mathrm{H}_{4}(72 \%), o-\mathrm{EtOC}_{6} \mathrm{H}_{4}(44 \%)$, $m-\mathrm{HOC}_{6} \mathrm{H}_{4}(0 \%)$, 2-naphthyl (82\%), 3-pyridinyl (39\%)

$\mathrm{R}=\mathrm{Me}, 120^{\circ} \mathrm{C}, 24 \mathrm{~h}, \mathrm{Ar}=2$-naphthyl $(34 \%, 49 \%$ conversion)

Scheme 25. C- and N-methyl and ethylations.

The difference between the results-methylation versus methylenation-of $N, N$ dimethyl-2-arylacetamides (Scheme 25a versus Scheme 26) is surprising but the authors did not cite the first report and, consequently, did not make comments. $N, N$-Dimethyl2-phenylacetamide (Scheme 25a) [80] and 2-(4-methoxyphenyl)- $\mathrm{N}, \mathrm{N}$-dimethylacetamide (Scheme 26) [81] were treated at $120^{\circ} \mathrm{C}$ with same amounts of $t$-BuOK and amine-borane. 
Y.-F. Wang's team assumed that the methylation product implicates the reduction of the methylenation product [80]. According to the two reports [80,81], deprotonation of the substrate (noted $\mathrm{ArCH}_{2} \mathrm{E}$ ) mediates addition to DMF leading to $\mathrm{ArECHCH}(\mathrm{OH}) \mathrm{NMe}_{2}$ which evolves toward the imminium ArECHCH$=\mathrm{N}^{\oplus} \mathrm{Me}_{2}$. Subsequent reduction with $\mathrm{Me}_{2} \mathrm{NH}-\mathrm{BH}_{3}$ into ArECHCHH$\left(\mathrm{NMe}_{2}\right)$ is followed by base-mediated elimination of $\mathrm{HNMe}_{2}$ leading to $\mathrm{ArEC}=\mathrm{CHH}$ and then the methylation product. The nature of the final product could depend on the reaction time. Indeed, the methylenation product was isolated after $40 \mathrm{~min}$ while the methylation reaction went on for $11 \mathrm{~h}$. Moreover, decreasing the reaction time to $5 \mathrm{~h}$ afforded a mixture of the two products (Scheme 27( $\left.\left.\mathrm{a}_{1}\right)\right)$ [80]. The hypothesis of the effect of the reaction time, however, disagrees with the reduction of acrylonitrile in 5 min under the $t$-BuOK/ $/ \mathrm{Me}_{2} \mathrm{NH}-\mathrm{BH}_{3} / \mathrm{HCONMe} 2$ conditions (Scheme 27( $\left.\mathrm{a}_{2}\right)$ ) [80]. In conclusion, the interpretation of the results depicted in Schemes 25a and 26 remains an open question.

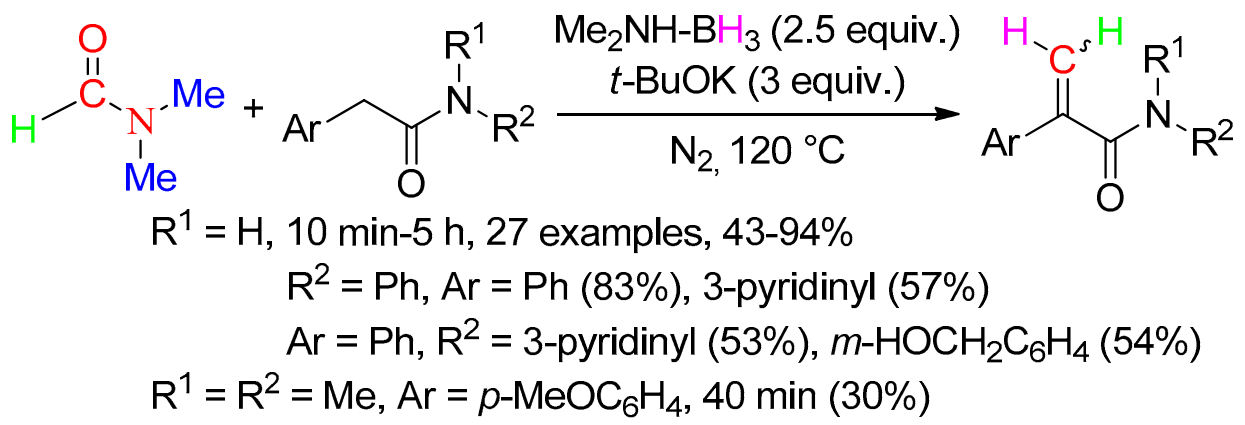

Scheme 26. Direct $\mathrm{Csp}^{3}$ methylenation.

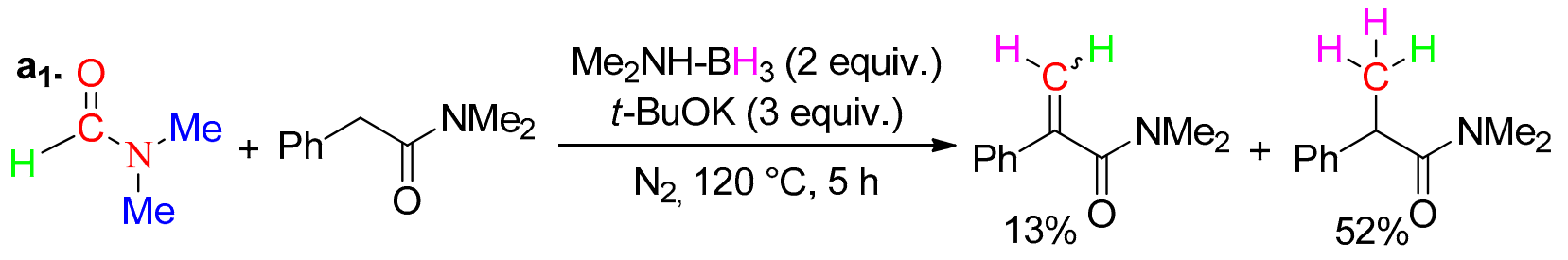

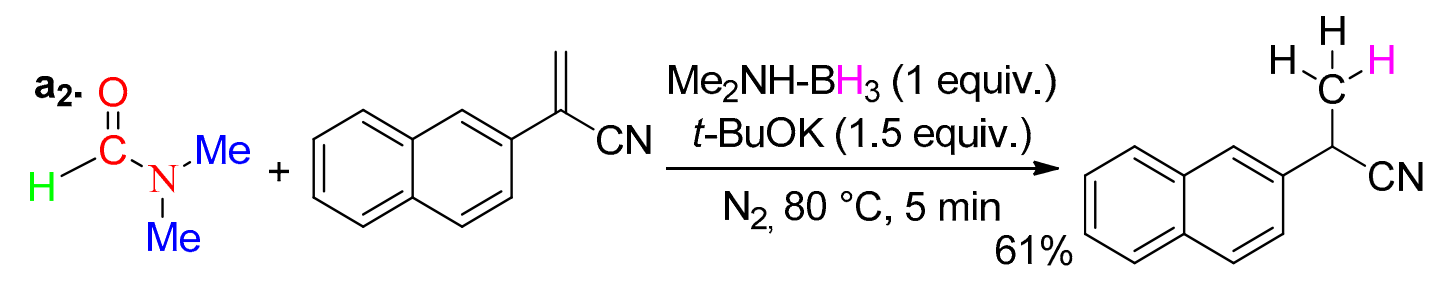

Scheme 27. Methylation versus methylenation and hydrogen transfer.

Liang's team revealed the triflic anhydride-mediated formylation of $N$-methylindole depicted in Scheme 28 $\left(\mathrm{a}_{1}\right)$ [83]. The reaction proceeds through nucleophilic addition of the substrate to enolium triflate of DMF giving the corresponding iminium (Scheme 28 $\left(\mathrm{a}_{2}\right)$ ) $[83,84]$. Subsequent hydrolysis delivers the product. 


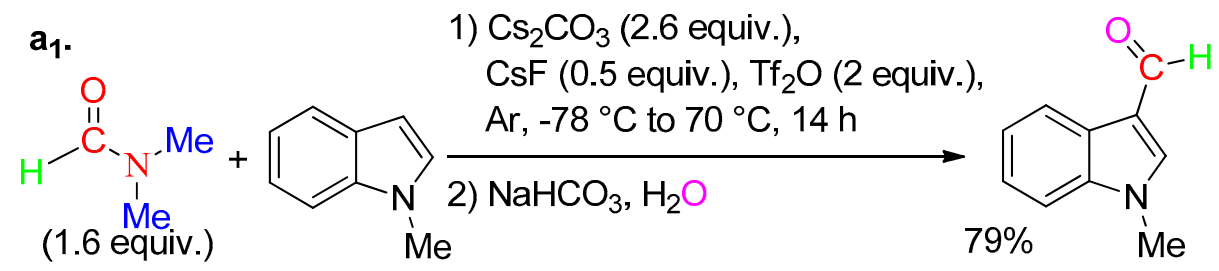

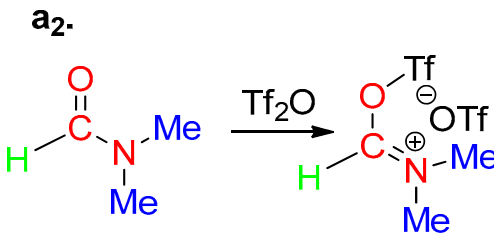<smiles>Cn1ccc2ccccc21</smiles><smiles>CN(C)/C=C/c1cn(C)c2ccccc12</smiles><smiles>Cn1cc(C=O)c2cc(S(=O)(O)(O)Cl)ccc21</smiles>

Scheme 28. $\mathrm{Tf}_{2} \mathrm{O}$-mediated formylation of $\mathrm{N}$-methylindole.

\section{2. $\mathrm{HCNMe}_{2}$ Fragment}

Mechanistic investigations of the reaction depicted in Scheme 25a led Y.-F. Wang's team to observe a slow reaction of the methylation product with the amine-borane/DMF system (Scheme 29a) [80]. The iminium intermediate $\operatorname{ArCMe}(\mathrm{CN}) \mathrm{CH}=\mathrm{N}^{\oplus} \mathrm{Me}_{2}$, produced by deprotonation of the substrate and addition to DMF as documented above, is reduced with amine-borane.
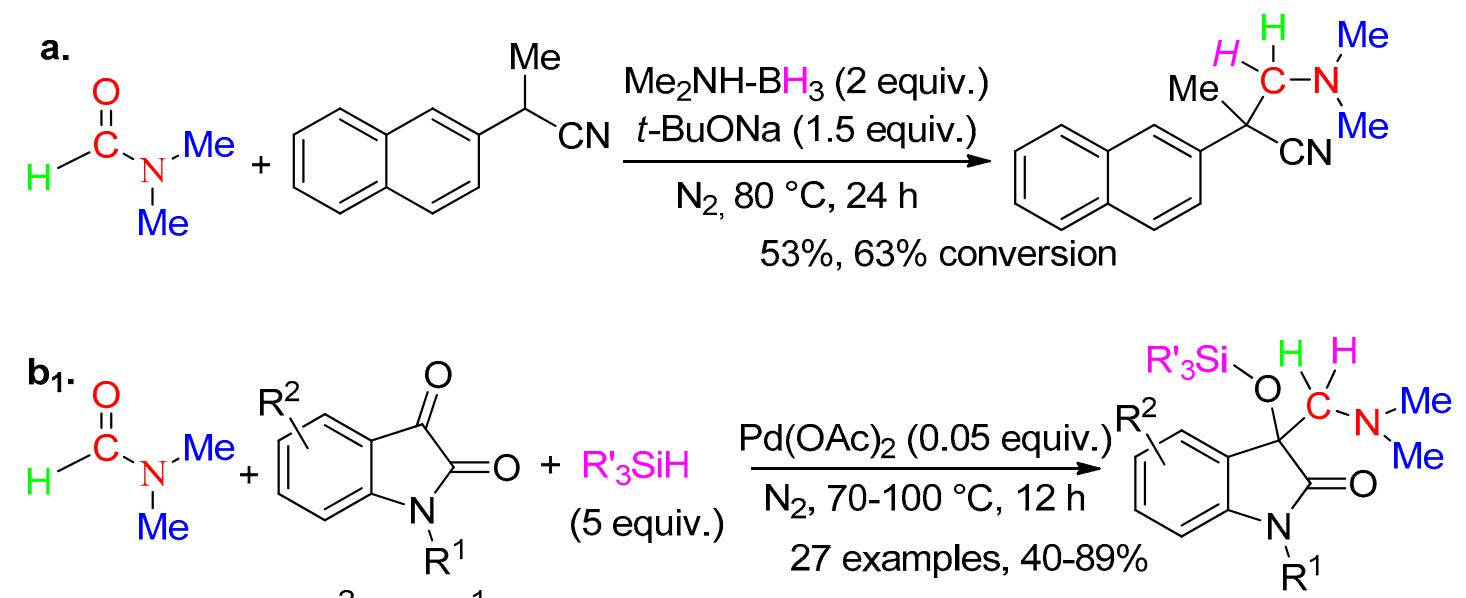

$\mathrm{R}^{\prime}=\mathrm{Et}, \mathrm{R}^{2}=\mathrm{H}, \mathrm{R}^{1}=\mathrm{Me}(89 \%), \mathrm{Ph}(85 \%), p-\mathrm{MeC}_{6} \mathrm{H}_{4} \mathrm{CH}_{2}(66 \%)$

$\mathrm{R}^{\prime \prime}=\mathrm{Et}, \mathrm{R}^{1}=\mathrm{H}, \mathrm{R}^{2}=4-\mathrm{MeO}_{2} \mathrm{C}(65 \%), 5-\mathrm{MeO}(82 \%), 5-\mathrm{CN}(40 \%)$

$\mathrm{R}^{1}=\mathrm{Me}, \mathrm{R}^{2}=\mathrm{H}, \mathrm{R}^{\prime}=t-\mathrm{Bu}(66 \%), n-\mathrm{Bu}(61 \%)$

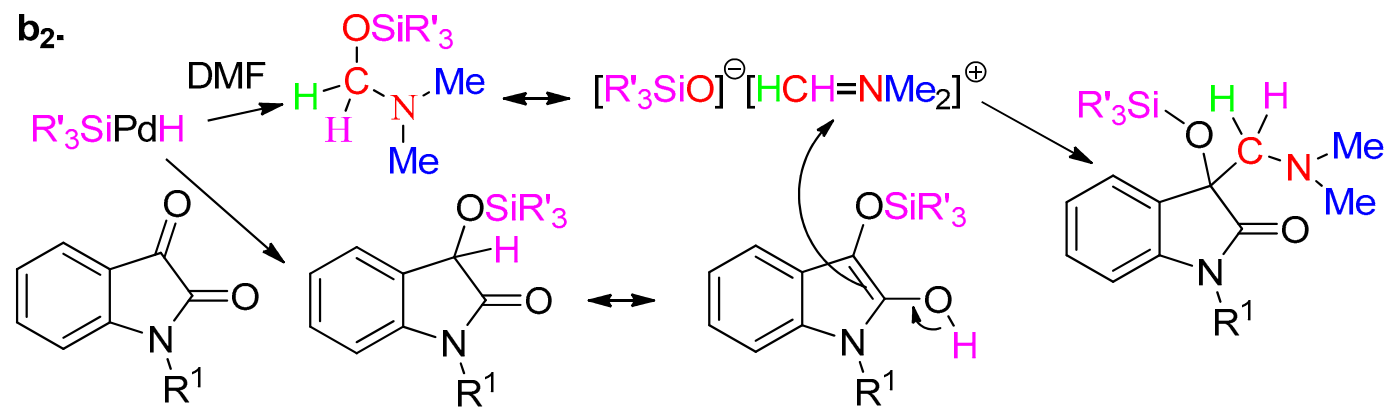

Scheme 29. Substitution of a tertiary Csp3-H or addition to a carbonyl group. 
The 3-carbonyl group of isatins underwent both hydrosilylation and amino-methylation using hydrosilanes and Pd catalysis in DMF (Scheme 29(b $\left.b_{1}\right)$ ) [85]. According to Wu's team, $\mathrm{Pd}^{0}$ produced from the silane-mediated reduction of $\mathrm{Pd}(\mathrm{OAc})_{2}$, inserts into the $\mathrm{Si}$ $-\mathrm{H}$ bond of the silane giving $\mathrm{R}_{3}{ }_{3} \mathrm{SiPdH}$, which undergoes two different hydrosilylations (Scheme $\left.29\left(b_{2}\right)\right)$. That of DMF affords $\left(\mathrm{R}_{3}{ }_{3} \mathrm{SiO}\right) \mathrm{HCHNMe}_{2}$ which transforms into $\left[\left(\mathrm{R}_{3}{ }_{3} \mathrm{Si}\right.\right.$ $\mathrm{O})]^{\ominus}\left[\mathrm{HCH}=\mathrm{NMe}_{2}\right]^{\oplus}$, while that of the $\mathrm{C} 3$ carbonyl of isatin provides $\mathrm{O}$-silylated indolin-2one which tautomerizes into the corresponding silyl enol ether. The addition of the latter to the iminium species gives the product.

\section{HC-O Fragment}

1,3-Bromoesters have been isolated from the reaction of aryl cyclopropanes with NBS, $\mathrm{DMF}$, and $\mathrm{H}_{2} \mathrm{O}$ (Scheme $30\left(\mathrm{a}_{1}\right)$ ), which involves bromination of the three-membered ring leading to carbocation $\mathrm{ArR}^{1} \mathrm{C}^{\oplus} \mathrm{CH}_{2} \mathrm{CH}_{2} \mathrm{Br}$ [86]. The subsequent attack of the oxygen of DMF via $\mathrm{S}_{\mathrm{N}} 1$ or $\mathrm{S}_{\mathrm{N}} 2$ mechanism affords $\operatorname{ArR}^{1} \mathrm{C}\left(\mathrm{OCH}=\mathrm{N}^{\oplus} \mathrm{Me}_{2}\right)\left(\mathrm{CH}_{2} \mathrm{CH}_{2} \mathrm{Br}\right)$ which undergoes hydrolysis delivering the bromoester. The reaction of 1,2-diphenylcyclopropane under the same experimental conditions arose with good diastereoselectivity (Scheme 30 $\left(a_{2}\right)$ ).
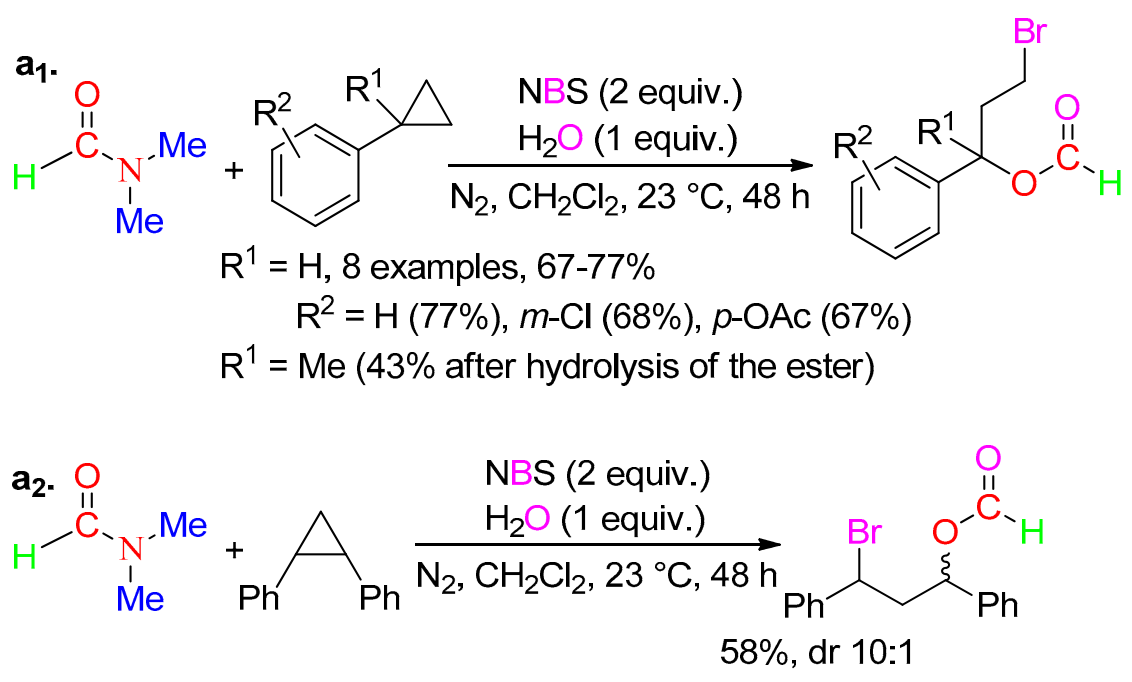

Scheme 30. 1,3-difunctionalization of aryl cyclopropanes.

\section{4. $\mathrm{RC}=\mathrm{O}$ Fragment}

The regioselective 2-formylation of 3-bromobenzofuran and 3-bromobenzothiophene was achieved with NaHMDS and DMF at low temperature in THF, while the C5 position was favored at room temperature (Scheme 31a) [87]. Formylation of a variety of fivemembered heteroarenes succeeded at room temperature with in situ generated amide base (Scheme 31b) [88]. The latter reactions proceed via proton abstraction and nucleophilic addition of the resulting carbanion to DMF.

The transamidation of amines has been carried out under a variety of conditions [89]. A rather surprising procedure using methyl benzoate under microwave irradiation in DMF achieved the formylation of aliphatic primary and secondary amines (Scheme 32a) [90]. Jeon and Yang speculated a transition state implicating amine, methyl benzoate, and DMF. L-Proline at $150{ }^{\circ} \mathrm{C} \mathrm{[91]} \mathrm{and} \mathrm{Fe}^{\mathrm{III}}$ salts in refluxing toluene [92] were used to catalyze the formylation of benzylamine with DMF (Scheme 32b,c). The reaction of L-proline with DMF would precede the nucleophilic addition of the amine, while $\mathrm{Fe}^{\mathrm{III}}$ would form a DMF complex that reacts with the amine. Triflic acid catalyzed the formylation of tetrahydroisoquinoline with DMF (Scheme 32d) [93]. In fact, formylations with DMF arose at $150{ }^{\circ} \mathrm{C}$ even in the absence of an additive, in fair to high yields from various aliphatic amines and a low yield from $p$-methoxyaniline (Scheme 33a) [94]. 


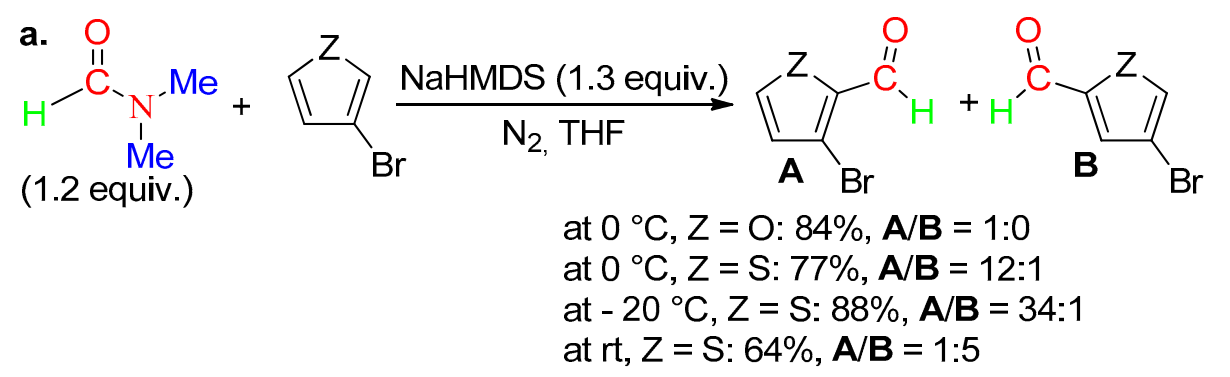

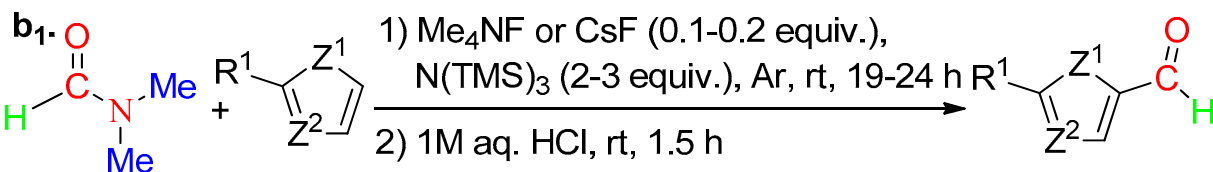

$$
\begin{aligned}
& \mathrm{Z}^{1}=\mathrm{S}, \mathrm{Z}^{2}=\mathrm{CH}, 8 \text { examples, } 62-93 \% \\
& \mathrm{R}^{1}=\mathrm{Ph}(77 \%) \text {, 2-pyridinyl (67\%), CONMePh (86\%) } \\
& Z^{1}=\mathrm{O}, Z^{2}=N, R^{1}=P h(90 \%)
\end{aligned}
$$

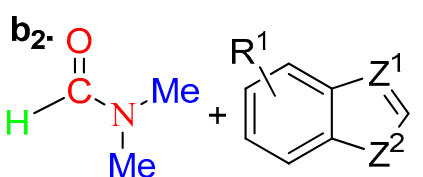
1) $\mathrm{Me}_{4} \mathrm{NF}$ or $\mathrm{CsF}(0.1-0.2$ equiv. $)$,
$\mathrm{N}(\mathrm{TMS})_{3}(2-3$ equiv.), $\mathrm{Ar}, \mathrm{rt}, 19-24 \mathrm{~h}$
2) $1 \mathrm{M}$ aq. $\mathrm{HCl}, \mathrm{rt}, 1.5 \mathrm{~h}$ 11 examples, $67-93 \%$

$$
\begin{aligned}
& \mathrm{R}^{1}=\mathrm{H}, \mathrm{Z}^{2}=\mathrm{S}, \mathrm{Z}^{1}=\mathrm{CH}(93 \%), \mathrm{CBr}(74 \%), \mathrm{N}(67 \%) \\
& \mathrm{R}^{1}=\mathrm{H}, \mathrm{Z}^{2}=\mathrm{NMe}, \mathrm{Z}^{1}=\mathrm{CCN}(88 \%)
\end{aligned}
$$

Scheme 31. Formylation of 5-membered heteroarenes.

Potassium and sodium tert-butoxides mediated the formylation and acetamidation of primary aliphatic and arylamines with DM (Scheme 33b-d) [95-97]. The teams of Dash [96] and Cheng/Chen [97] performed the reactions with DMF and DMAc at room temperature (Scheme 33c,d), while, in contrast to DMF, the Li/Yu team carried out the reactions with DMAc at $130{ }^{\circ} \mathrm{C}$ and under microwave irradiation to reduce the reaction time (Scheme 33b) [95]. The $t$-BuOK-mediated reaction of cyclopropylamine provided the transamidation product in a poor yield at room temperature and $\mathrm{N}$-(prop-1-en-1yl)acetamide in fair yield at $80^{\circ} \mathrm{C}$ (Scheme 32e) [96]. Effective transamidations of primary amines with DM were reported under catalysis with imidazolium chloride at $150{ }^{\circ} \mathrm{C}$ (Scheme 33f) [98] or using 1-2 equiv. of ammonium iodide at $125-145^{\circ} \mathrm{C}$ (Scheme 33g) [99].

Basic conditions implicate the deprotonation of the amine and the tetrahedral ionic species $\left(\mathrm{R}^{1} \mathrm{HN}\right) \mathrm{CRO}^{\ominus}\left(\mathrm{NMe}_{2}\right)$ which converts into the product. According to the $\mathrm{Li} / \mathrm{Yu}$ team, the mechanism depends on the nature of the base: no radical character of the $t$ $\mathrm{BuONa}$-based reaction while two pathways were plausible with $t$-BuOK [95]. With $t$-BuOK, $\left(\mathrm{R}^{1} \mathrm{HN}\right) \mathrm{CRO}^{\ominus}\left(\mathrm{NMe}_{2}\right)$ would be obtained either from the reaction between $\mathrm{R}^{1} \mathrm{HN}{ }^{\ominus}$ and a $\mathrm{I}_{6} / \mathrm{t}$-BuOK complex or via the equilibrium $\mathrm{R}^{1} \mathrm{HN}^{\ominus} \rightleftharpoons \mathrm{R}^{1} \mathrm{HN}^{\cdot}+\mathrm{e}^{\ominus}$, allowing a single electron transfer to form the radical anion $\mathbf{I}_{8}\left(\mathrm{RC}^{\cdot} \mathrm{O}^{\ominus}\left(\mathrm{NMe}_{2}\right)\right)$. Coupling of the latter with $\mathrm{R}^{1} \mathrm{HN}$ 'leads to $\left(\mathrm{R}^{1} \mathrm{HN}\right) \mathrm{CRO}^{\ominus}\left(\mathrm{NMe}_{2}\right)$.Such a radical pathway agrees with subsequent EPR and ESI-MS studies performed by Dash's team [96]. For the $t$-BuONa-based reaction, Cheng/Chen team proposed a mechanism without single-electron transfer (Scheme 33e). Both DM and amine are separately activated via coordinative interactions with $t$-BuONa. The reaction between the two entities leads to a tetrahedral intermediate which undergoes proton transfer. Subsequent elimination of $\mathrm{HNMe}_{2}$ delivers the desired amide [97]. The difference between the $t$-BuOK and $t$-BuONa reaction pathways was assigned to the stronger basicity of the former and its good single-electron transfer properties [97]. 


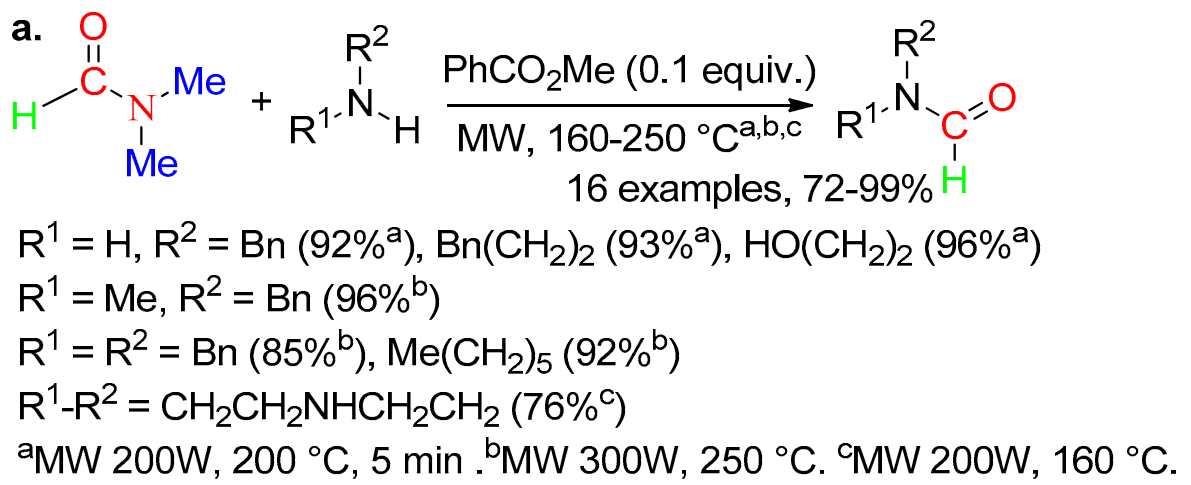

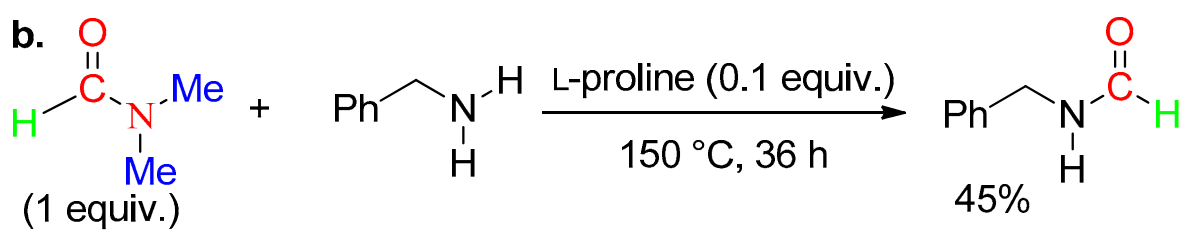

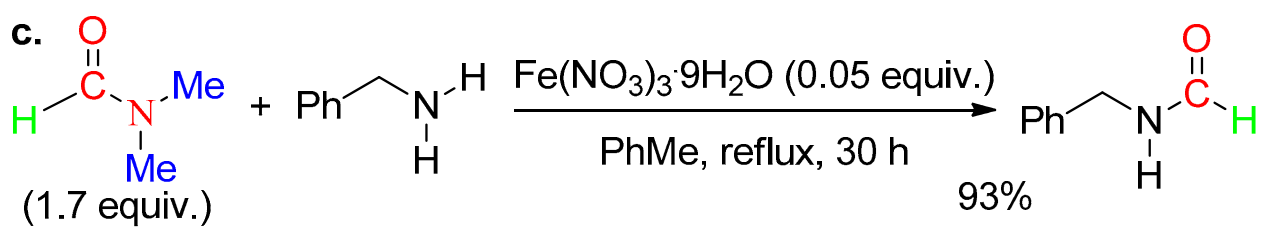

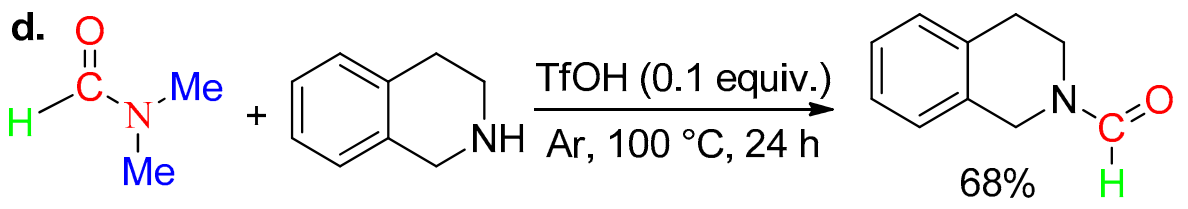

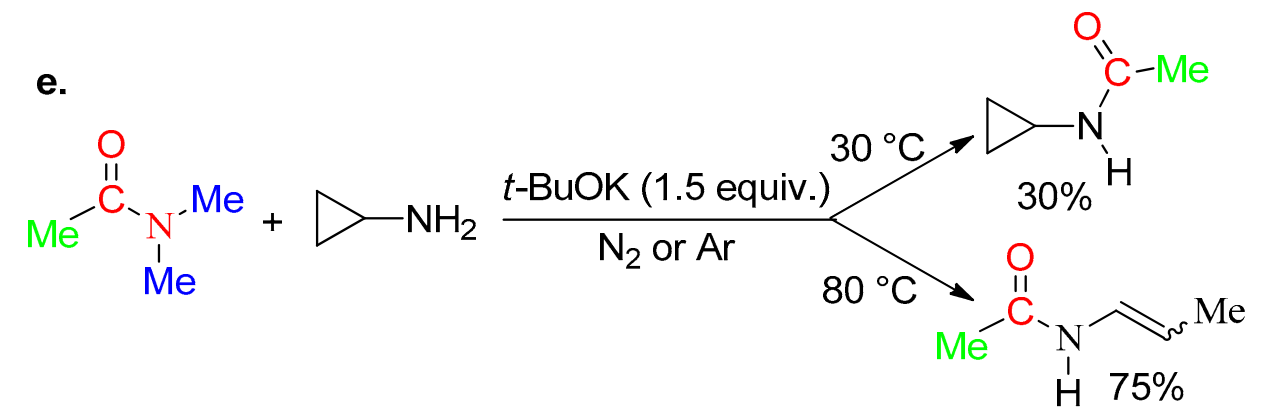

Scheme 32. Amidation of aliphatic amines.

The imidazolium chloride-based reaction (Scheme 33f) would involve the protonation of DM, promoting the nucleophilic addition of imidazole leading to $\mathrm{C}_{3} \mathrm{H}_{3} \mathrm{~N}_{2} \mathrm{COR}$. Subsequent amine addition gives $\mathrm{C}_{3} \mathrm{H}_{3} \mathrm{~N}_{2} \mathrm{C}(\mathrm{OH}) \mathrm{R}\left(\mathrm{NHR}^{1}\right)$ which evolves toward the product via elimination of imidazole.

Various acidic conditions in $\mathrm{DM}$, in particular $\mathrm{HCl}$ catalysis at $120^{\circ} \mathrm{C}$, achieved the formation of $\mathrm{N}$-phenylamides from $\beta$-ketobutylanilides (Scheme 34a) [100]. According to Chen's team, the substrate decomposes into the corresponding anilide which undergoes reaction with protonated DMF. In fact, the same laboratory subsequently reported the amidation of primary arylamines using a stoichiometric amount of aqueous $\mathrm{HCl}$ in $\mathrm{DM}$ at $100{ }^{\circ} \mathrm{C}$ (Scheme 34b) [101]. Recently, Karpoormath's team used a similar procedure for amidation with DMF of primary and secondary amines (Scheme 34c) [102]. Martínez-Pascual and co-workers, who performed the formylation of anilines and secondary aliphatic amines using the beforehand prepared DMF$\cdot \mathrm{HCl}$ complex, reported a domino reaction leading to 
4-arylpiperazine-1-carbaldehydes from anilines, bis(2-chloroethyl)amine hydrochloride, and DMF (Scheme 34d) [103].Camphor sulfonic acid was the optimum carboxylic acid for $\mathrm{N}$-formylation of 2-aminophenols at $100{ }^{\circ} \mathrm{C}$ (Scheme 34e) [104]. In contrast, Lewis acids such as tert-butyldimethylsilyl triflate promoted the room temperature formylation of primary or secondary aliphatic amines and anilines (Scheme 33h) [105]. Heating was required for the amidation of arylamines mediated with graphene oxide under neat conditions (Scheme 34f) [106].

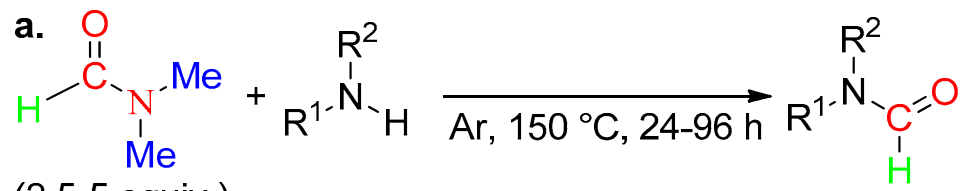

(2.5-5 equiv.)

$R^{1}, R^{2} \neq A r, 20$ examples, $50-99 \%$

$\mathrm{R}^{1}=\mathrm{H}, \mathrm{R}^{2}=\mathrm{Bn}(75 \%), \mathrm{BnCH}_{2}(86 \%), \mathrm{PhCH}(\mathrm{OH}) \mathrm{CH}_{2}(58 \%)$

$\mathrm{R}^{1}=\mathrm{Me}, \mathrm{R}^{2}=\mathrm{Bn}(80 \%), \mathrm{BnCH}_{2}(99 \%), 1$-naphthylCH $\mathrm{ICH}_{2}(86 \%)$

$\mathrm{R}^{1}-\mathrm{R}^{2}=\mathrm{CH}_{2} \mathrm{CH}_{2} \mathrm{CHPhCH}_{2} \mathrm{CH}_{2}(91 \%)$

$\mathrm{R}^{1}=\mathrm{H}, \mathrm{R}^{2}=p-\mathrm{MeOC}_{6} \mathrm{H}_{4}(26 \%)$

b. $O$

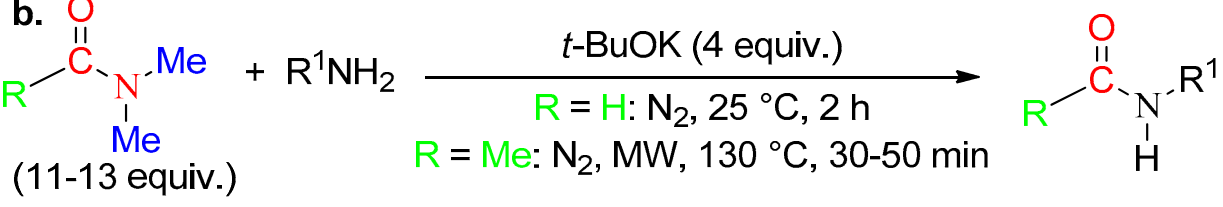

$\mathrm{R}=\mathrm{H}, 15$ examples, $80-99 \%$

$\mathrm{R}^{1}=\mathrm{Ph}(96 \%), 2-$ pyridinyl (90\%), 2-pyrimidinyl (90\%), Cy (85\%)

$\mathrm{R}=\mathrm{Me}, 14$ examples, $70-99 \%$

$\mathrm{R}^{1}=\mathrm{Ph}\left(96 \%{ }^{\mathrm{a}}\right)$, 2-pyridinyl (95\%), $\mathrm{Bn}(90 \%), \mathrm{Me}\left(\mathrm{CH}_{2}\right)_{7}(81 \%)$

${ }^{\mathrm{a}} 96 \%$ at $130{ }^{\circ} \mathrm{C}$ for $6 \mathrm{~h}$ in the absence of $\mathrm{MW}$.

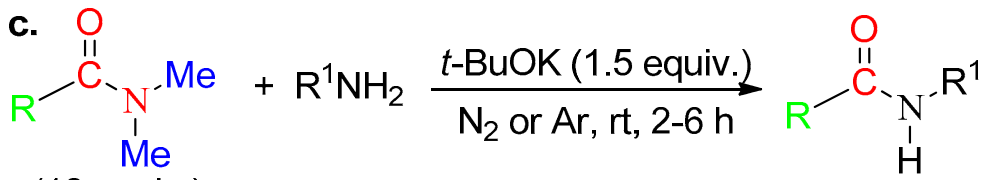

(10 equiv.)

$\mathrm{R}=\mathrm{H}, 26$ examples, $<10-97 \%$

$\mathrm{R}^{1}=\mathrm{Ph}(94 \%), 2-\mathrm{NCC}_{6} \mathrm{H}_{4}(84 \%), 2,5-\mathrm{Me}_{2} \mathrm{C}_{6} \mathrm{H}_{4}(<10 \%)$,

4-pyridinyl (82\%), $\mathrm{Me}\left(\mathrm{CH}_{2}\right)_{15}(82 \%)$, allyl $(65 \%)$

$\mathrm{R}=\mathrm{Me}, 21$ examples, $30-87 \%$

$\mathrm{R}^{1}=\mathrm{Ph}(87 \%), 2-\mathrm{NCC}_{6} \mathrm{H}_{4}(80 \%), 4-\mathrm{O}_{2} \mathrm{NCC}_{6} \mathrm{H}_{4}(47 \%)$,

4-pyridinyl (78\%), cyclopropyl (30\%)

Scheme 33. Cont. 
d.<smiles>[R][R1]([H])NC([R])=O</smiles>

(3 equiv.)

$\mathrm{R}=\mathrm{H}, 18$ examples, $65-97 \%$

$$
\mathrm{R}^{1}=\mathrm{Ph}(95 \%), p-\mathrm{NCC}_{6} \mathrm{H}_{4}(88 \%), p-\mathrm{PhNHC}_{6} \mathrm{H}_{4}(78 \%)
$$

2-pyridinyl (71\%), $\mathrm{Me}\left(\mathrm{CH}_{2}\right)_{5}(94 \%), \mathrm{Ph}\left(\mathrm{CH}_{2}\right)_{2}(81 \%)$

$\mathrm{R}=\mathrm{Me}, \mathrm{R}^{1}=\mathrm{Ph}(65 \%)$

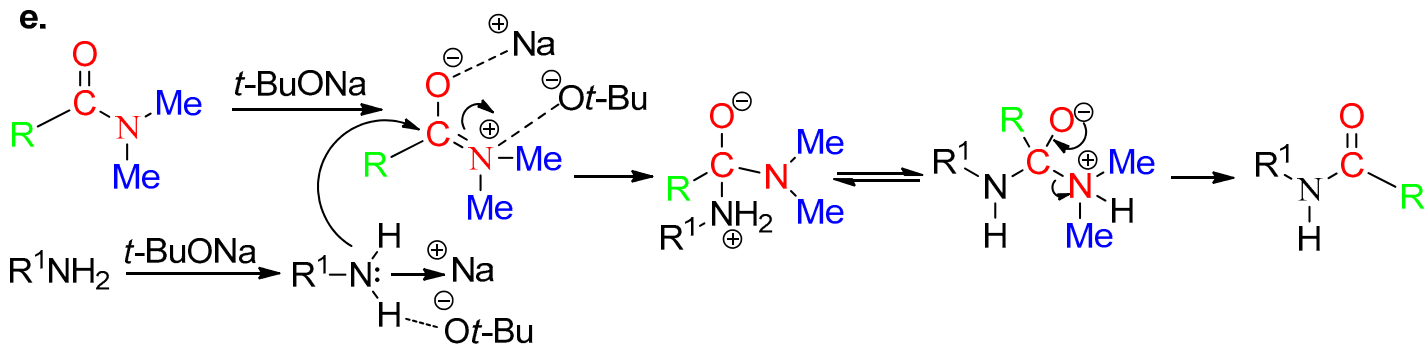

f.

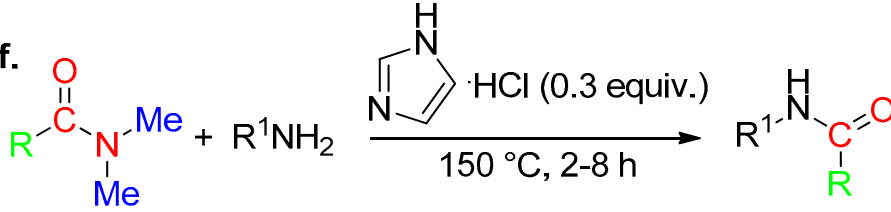

$\mathrm{R}=\mathrm{H}, 5$ examples, $71-92 \%$ $\mathrm{R}^{1}=\mathrm{Ph}(89 \%), m-\mathrm{O}_{2} \mathrm{NC}_{6} \mathrm{H}_{4}(71 \%), \mathrm{Bn}(92 \%)$

$\mathrm{R}=\mathrm{Me}, 23$ examples, $57-97 \%$

$\mathrm{R}^{1}=\mathrm{Ph}(92 \%), m-\mathrm{O}_{2} \mathrm{NC}_{6} \mathrm{H}_{4}(63 \%), \mathrm{Bn}(93 \%)$

$\mathrm{PhCHMe}(94 \%)$,<smiles>Cc1cccc2sc(C(C)C)nc12</smiles>

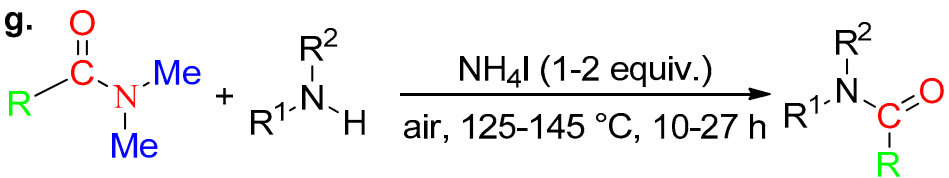

$\mathrm{R}=\mathrm{H}, 24$ examples, 23-94\%

$\mathrm{R}^{1}=\mathrm{H}, \mathrm{R}^{2}=\mathrm{Ph}$ (82\%), Bn (94\%), 2-pyridinyl (42\%)

$\mathrm{R}^{1}=\mathrm{R}^{2}=n-\mathrm{Bu}(51 \%)$

$\mathrm{R}^{1}-\mathrm{R}^{2}=\left(\mathrm{CH}_{2}\right)_{2} \mathrm{O}\left(\mathrm{CH}_{2}\right)_{2}(23 \%)$

$\mathrm{R}=\mathrm{Me}, 5$ examples, $29-52 \%$

$\mathrm{R}^{1}=\mathrm{H}, \mathrm{R}^{2}=\mathrm{Ph}(45 \%), p-\mathrm{MeOC}_{6} \mathrm{H}_{4}(52 \%), p-\mathrm{HOC}_{6} \mathrm{H}_{4}(29 \%)$

h.

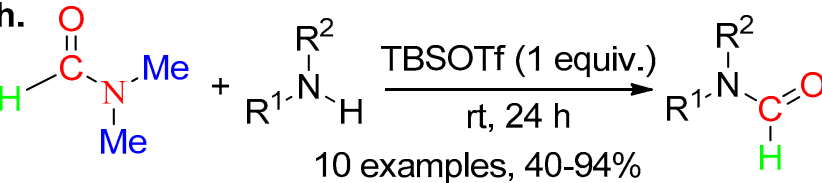

$\mathrm{R}^{1}=\mathrm{H}, \mathrm{R}^{2}=\mathrm{Ph}(67 \%), \mathrm{Bn}(40 \%), \mathrm{Bn}\left(\mathrm{CH}_{2}\right)(59 \%)$

$\mathrm{R}^{1}=\mathrm{Me}, \mathrm{R}^{2}=\mathrm{Ph}(82 \%), \mathrm{Bn}(94 \%)$

$\mathrm{R}^{1}-\mathrm{R}^{2}=\mathrm{CH}_{2} \mathrm{CH}_{2} \mathrm{OCH}_{2} \mathrm{CH}_{2}(77 \%)$ 
i.

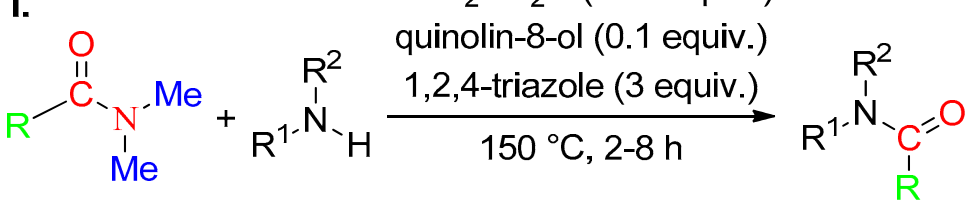

$\mathrm{R}=\mathrm{H}, 27$ examples, 52-99\%

$\mathrm{R}^{1}=\mathrm{H}, \mathrm{R}^{2}=\mathrm{Ph}(94 \%), m-\mathrm{O}_{2} \mathrm{NC}_{6} \mathrm{H}_{4}(52 \%), \mathrm{Cy}(99 \%)$

$\mathrm{R}^{1}-\mathrm{R}^{2}=\left(\mathrm{CH}_{2}\right)_{5}(99 \%),\left(\mathrm{CH}_{2}\right)_{2} \mathrm{O}\left(\mathrm{CH}_{2}\right)_{2}(98 \%)$

$\mathrm{R}=\mathrm{Me}, 20$ examples, $52-99 \%$

$\mathrm{R}^{1}=\mathrm{H}, \mathrm{R}^{2}=\mathrm{Ph}(93 \%), m-\mathrm{O}_{2} \mathrm{NC}_{6} \mathrm{H}_{4}(52 \%), \mathrm{Cy}(99 \%)$

$\mathrm{R}^{1}-\mathrm{R}^{2}=\left(\mathrm{CH}_{2}\right)_{5}(95 \%)$

j.

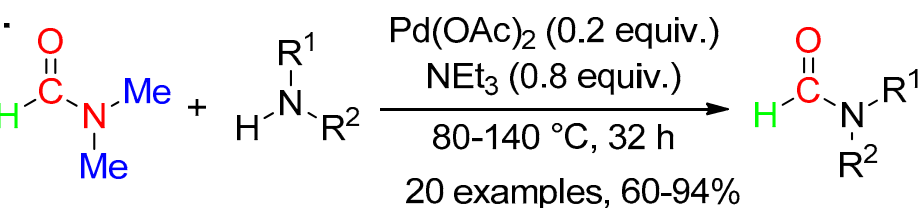

$\mathrm{R}^{1}=\mathrm{H}, \mathrm{R}^{2}=\mathrm{Ph}$ (89\%), 2-pyridinyl (82\%), Bn (89\%),

$\mathrm{Ph}\left(\mathrm{CH}_{2}\right)_{2}(93 \%), n-\mathrm{C}_{6} \mathrm{H}_{13}(83 \%)$

$\mathrm{R}^{1}=\mathrm{Me}, \mathrm{R}^{2}=\mathrm{Ph}(64 \%)$

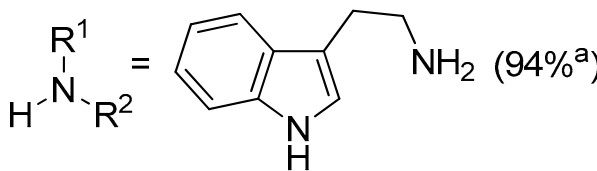

${ }^{a} 54 \%$ in the absence of $\mathrm{NEt}_{3}$.

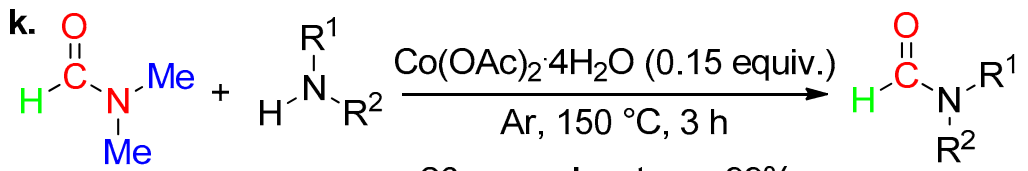

26 examples, trace-99\%

$\mathrm{R}^{1}=\mathrm{H}, \mathrm{R}^{2}=\mathrm{Bn}\left(86 \%^{\mathrm{a}}\right), \mathrm{Ph}\left(\mathrm{CH}_{2}\right)_{2}(97 \%), 1$-indanyl $(80 \%), n-\mathrm{C}_{12} \mathrm{H}_{25}(95 \%)$

$\mathrm{R}^{1}=\mathrm{Me}, \mathrm{R}^{2}=\mathrm{Bn}(72 \%), \mathrm{Ph}\left(\mathrm{CH}_{2}\right)_{2}(95 \%)$

$\mathrm{R}^{1}=\mathrm{Ph}, \mathrm{R}^{2}=\mathrm{H}$ (trace), Me (1\%)

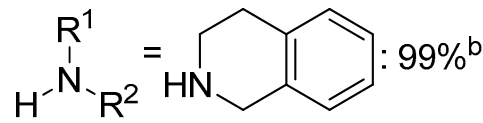

${ }^{2} 21 \%$ in the absence of the catalyst.

bOther catalysts: $\mathrm{Fe}(\mathrm{OAc})_{2} \cdot 4 \mathrm{H}_{2} \mathrm{O}(86 \%), \mathrm{Mn}(\mathrm{OAc})_{3} \cdot 2 \mathrm{H}_{2} \mathrm{O}(82 \%)$, $\mathrm{Ni}(\mathrm{OAc})_{2} \cdot 4 \mathrm{H}_{2} \mathrm{O}(82 \%), \mathrm{Cu}(\mathrm{OAc})_{2}(75 \%)$

Scheme 33. Amidation of aliphatic amines and arylamines.

$\mathrm{N}$-Amidation of aryl and aliphatic amines arose in high yields at $80-150{ }^{\circ} \mathrm{C}$ under $\mathrm{CuCl}_{2}$ (Scheme 33i) [107] or $\mathrm{PdCl}_{2}$ catalysis (Scheme 33j) [108] while $\mathrm{Co}(\mathrm{OAc})_{2}$ as catalyst was efficient only from aliphatic amines (Scheme 33k) [109]. The Cu-catalyzed reaction was carried out in the presence of 1,2,4-triazole. Jagtap's team assumed that this additive undergoes addition to $\mathrm{Cu}^{\mathrm{II}}$-coordinated $\mathrm{DM}$, resulting in the formation of $\mathrm{HNMe}_{2}$ and $\mathrm{Cu}^{\mathrm{II}}$-coordinated (1,2,4-triazol-1-yl)COR. Nucleophilic addition of $\mathrm{R}^{1} \mathrm{R}^{2} \mathrm{NH}$ to the latter followed by elimination of 1,2,4-triazole and $\mathrm{Cu}^{\mathrm{II}}$ affords the product [107]. Such a pathway contrasts with the proposal of Gong and co-workers who assumed the direct amine addition to the DMF $/ \mathrm{Co}^{\mathrm{II}}$ complex [109] as above alleged under Fe ${ }^{\mathrm{III}}$ catalysis [92]. No mechanism 
was indicated by L. Zhang's team for the Pd-catalyzed reaction [108]; the yield decreased in the absence of $\mathrm{NEt}_{3}$ (Scheme 33j), leading us to suspect a pathway similar to that mediated by $\mathrm{Cu}^{\text {II }}$.

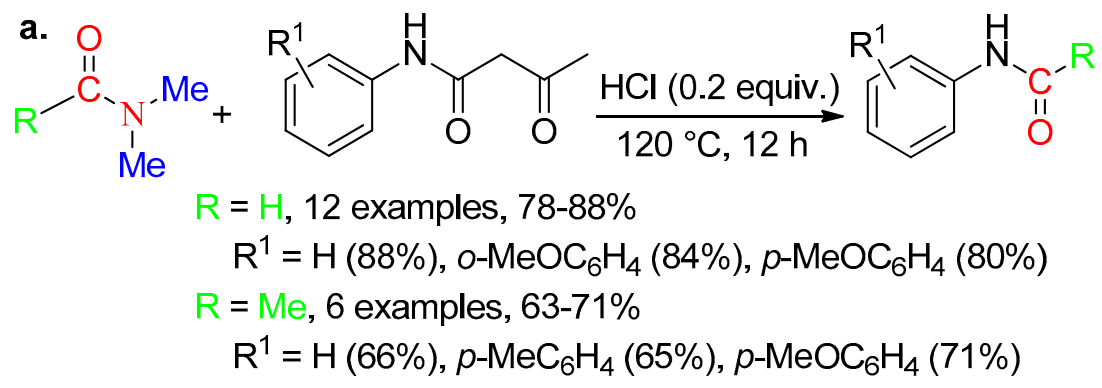

b. $\mathrm{O}$

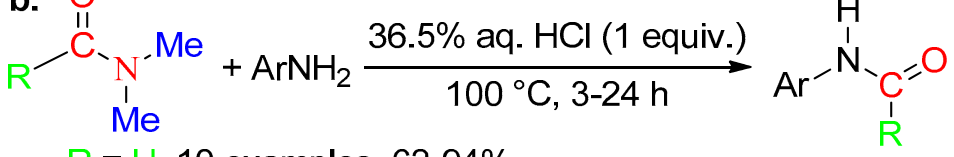

$$
\begin{aligned}
& \mathrm{R}=\mathrm{H}, 10 \text { examples, 62-94\% } \\
& \mathrm{Ar}=\mathrm{Ph}(90 \%), p-\mathrm{MeC}_{6} \mathrm{H}_{4}(86 \%), p-\mathrm{ClC}_{6} \mathrm{H}_{4}(94 \%) \\
& p-\mathrm{O}_{2} \mathrm{NC}_{6} \mathrm{H}_{4}(62 \%) \text {, 2-pyridinyl (72\%) } \\
& \mathrm{R}=\mathrm{Me}, 9 \text { examples, } 59-85 \% \\
& \mathrm{Ar}=\mathrm{Ph}(70 \%), p-\mathrm{MeC}_{6} \mathrm{H}_{4}(78 \%), p-\mathrm{ClC}_{6} \mathrm{H}_{4}(75 \%) \\
& p-\mathrm{O}_{2} \mathrm{NC}_{6} \mathrm{H}_{4}(59 \%) \text {, 2-pyridinyl (64\%) }
\end{aligned}
$$

c. O

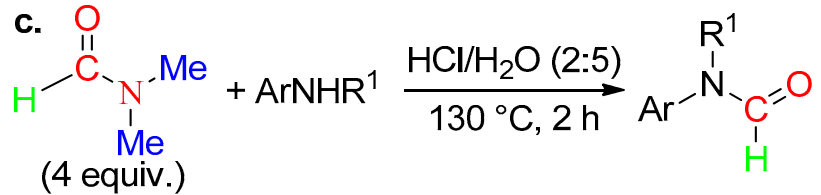

$\mathrm{R}^{1}=\mathrm{H}, 39$ examples, 0-93\%

$\mathrm{Ar}=\mathrm{Ph}(88 \%), o-\mathrm{HOC}_{6} \mathrm{H}_{4}(93 \%), p-\mathrm{ClC}_{6} \mathrm{H}_{4}(81 \%)$

$p-\mathrm{O}_{2} \mathrm{NC}_{6} \mathrm{H}_{4}$ (trace), 2-pyridinyl (trace)

$\mathrm{Ar}=\mathrm{Ph}, \mathrm{R}^{1}=\mathrm{Me}(38 \%), \mathrm{Bn}(23 \%)$

d.
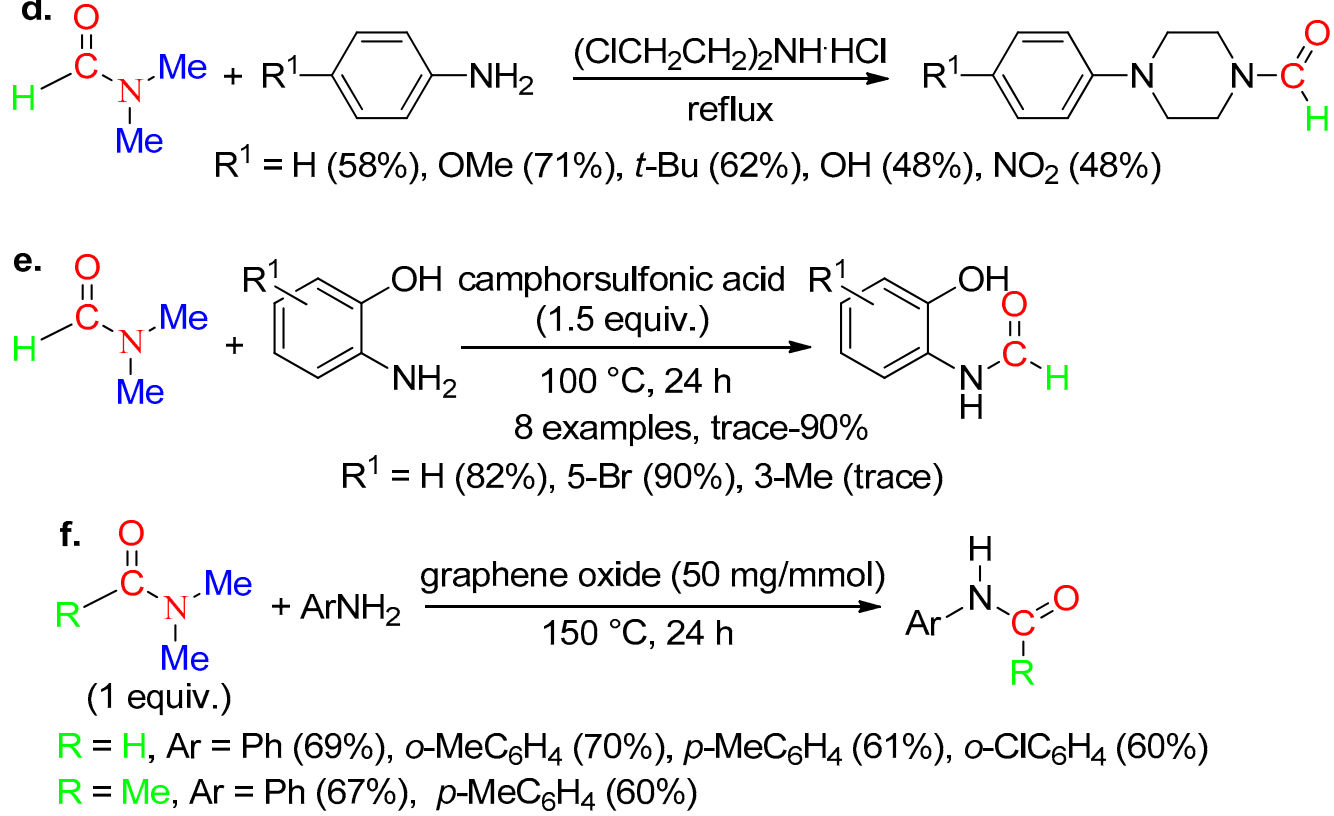

Scheme 34. Amidation of arylamines. 
Formylation and acetylation of hydrazides with tert-butyldimethylsilyl triflate and DM effectively occurred at room temperature (Scheme 35) [105].

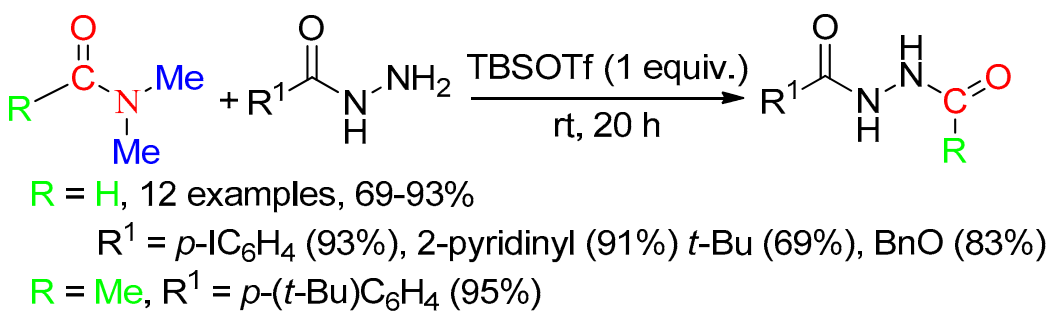

Scheme 35. Formylation and acetylation of hydrazides.

Siddiki, Shimizu, and co-workers disclosed the esterification of primary and secondary alcohols with DMAc using $\mathrm{CeO}_{2}$ at $155{ }^{\circ} \mathrm{C}$ in the presence of $\mathrm{HY}$ zeolite $\left(\mathrm{SiO}_{2} / \mathrm{Al}_{2} \mathrm{O}_{3}\right)$ (Scheme 36a) [110]. HY zeolite, enclosed in a paper filter placed at the upper portion of the reaction vessel, traps the dimethylamine formed from the $\mathrm{CeO}_{2}$-promoted cleavage of the $\mathrm{C}-\mathrm{N}$ bond of DMAc, which concomitantly affords a CeOCOMe species. Nucleophilic addition to the latter of the alcoholate formed from $\mathrm{CeO}_{2}$-mediated deprotonation of the alcohol provides the ester.

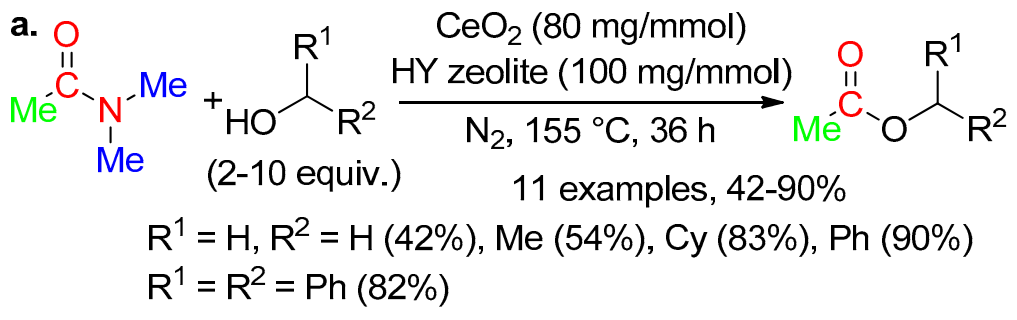

b.

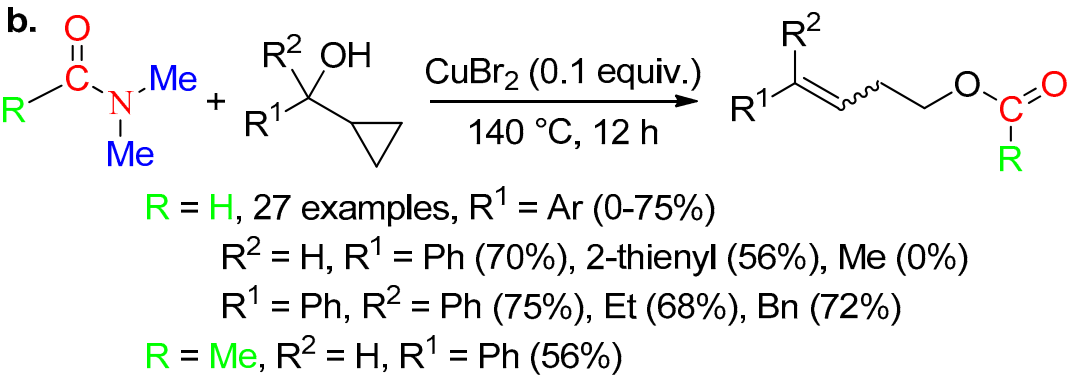

Scheme 36. $\mathrm{CeO}_{2}$-promoted alcoholysis of $\mathrm{DMAc}^{- \text {and }} \mathrm{CuBr}_{2}$-catalyzed ring opening/esterification of cyclopropyl carbinols.

Treatment at $140{ }^{\circ} \mathrm{C}$ in $\mathrm{DM}$ of cyclopropyl carbinols with catalytic amounts of $\mathrm{CuBr}_{2}$ provided alk-3-en-1-yl formates or acetates (Scheme 36b) via a copper alkoxide complex which evolves toward a homoallylic copper alcoholate [111]. Nucleophilic attack of the latter on DM results in the formation of the ester.

The formyl moiety of DMF would be involved in the formation of benzyl formate identified as a side reaction of the oxidation of benzyl bromide with a Zr-photocatalyst in DMF under air atmosphere [112].

Quaternary carbons have been synthetized from gem-bis(boronates), DMF and allyl methyl carbonates [113], (hetero)aryl iodides, or alkenyl bromides [114] using the procedures disclosed in Scheme 37. According to $\mathrm{Xu}$ and co-workers, the lithium salt obtained from treatment of $\left.\mathrm{R}^{1} \mathrm{R}^{2} \mathrm{C}[\mathrm{B}(\mathrm{pin}))\right]_{2}$ with $n$-BuLi, reacts with $\mathrm{DMF}$ to afford $\mathrm{R}^{1} \mathrm{R}^{2} \mathrm{C}=\mathrm{CH}[\mathrm{OB}(\mathrm{pin})]$. Transmetallation with $\mathrm{R}^{\prime} \mathrm{PdX}\left(\mathrm{R}^{\prime}\right.$ = substituted allyl, $\left.\mathrm{Ar}, \mathrm{CH}=\mathrm{CHAr}\right)$ leads to $R^{1} R^{2} C=C H\left(O P d R^{\prime}\right)$ which is in equilibrium with the tetrahedral intermediate $R^{1} R^{2} C\left(P d R^{\prime}\right)(C H=O)$. Then, reductive elimination of $P^{0}$ liberates $R^{1} R^{2} C R^{\prime}(C H=O)$. 
a.

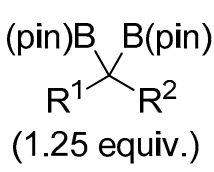

1) $n$-BuLi (1.25 equiv.), $\mathrm{THF}, \mathrm{Ar},-78^{\circ} \mathrm{C}, 30 \mathrm{~min}$ 2) $0{ }^{\circ} \mathrm{C}, 30 \mathrm{~min}$

3) addition to $\mathrm{Pd}(\mathrm{OAc})_{2}$ (0.1 equiv.), $\mathrm{PPh}_{3}$ (0.23 equiv.), $\mathrm{HCONMe}_{2}$ (130 equiv.)
4) $\mathrm{rt}, 10 \mathrm{~min}$<smiles>[R]C=C([R])COC(C)=O</smiles><smiles>[R]C=C([R])CC([R])([R])C=O</smiles>

34 examples, $31-89 \%$

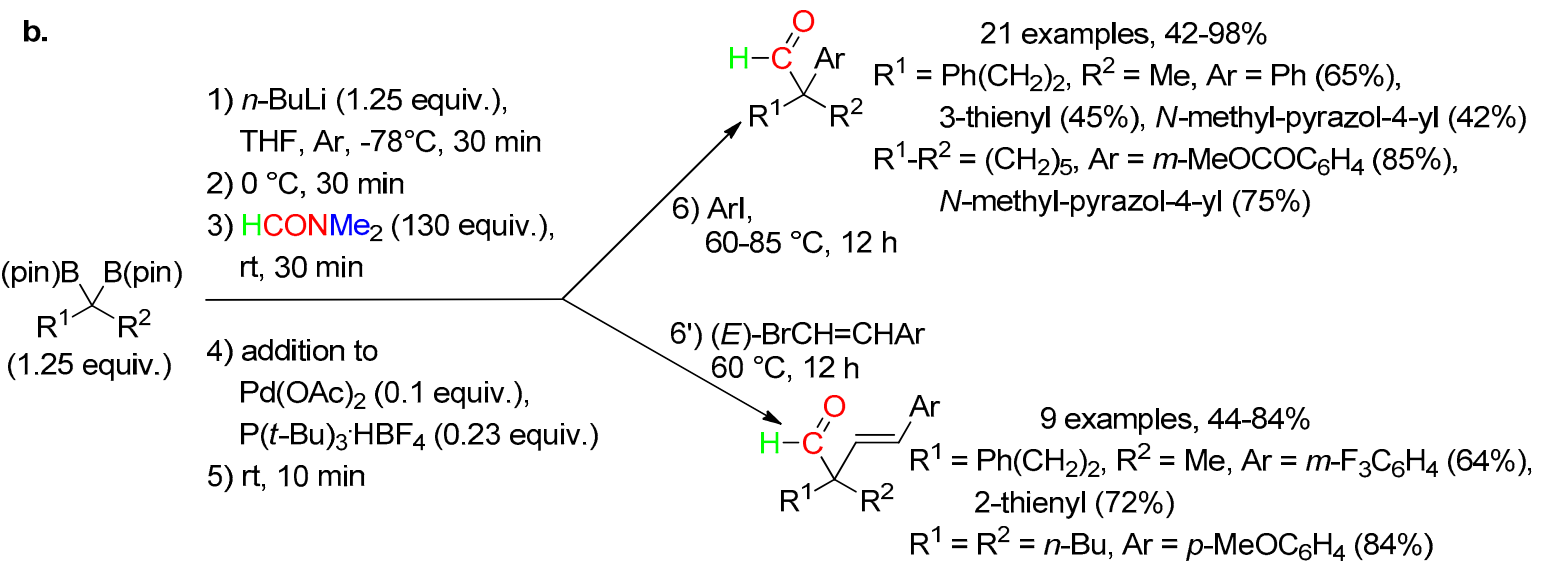

b.

Scheme 37. One-pot reactions.

\section{5. $\mathrm{RC}=\mathrm{ON}\left(\mathrm{CH}_{2}\right) \mathrm{Me}$ Fragment}

In 1976, Minisci's team disclosed the reaction of heteroarenes with DMF in the presence of sulfuric acid and oxidants [115]. Thus, 4-ethyl pyridine provided a mixture of 4-ethyl- $\mathrm{N}, \mathrm{N}$ dimethylpicolinamide and $N$-((4-ethylpyridin-2-yl)methyl)- $N$-methylformamide in yields and ratios depending on the oxidant (Scheme 38a). This seminal report was followed by intensive studies on the radical fragmentation of DM by Minisci and co-workers [116-118]. Then, the promotion of such reactions under sunlight, especially in the presence of $\mathrm{TiO}_{2}$, was disclosed by Caronna and co-workers (Scheme 38b) [119]. Subsequently, Weng's team reported that the amidoalkylaion method reported by the Huang/Zhu team [120] was improved using a photocatalyst and visible light (Scheme 38c) [121]. Togo's team previously highlighted the decisive effect of UV light on the amidoalkylation of 4-methylquinoline using DMAc, benzoyl peroxide, and trifluoroacetic acid (Scheme 38( $\left.\mathrm{d}_{1}\right)$ ) [122]. Various quinolines (Scheme $38\left(\mathrm{~d}_{2}\right)$ ), isoquinolines, and phenanthridines were amidoalkylated under such conditions [122]. Then, Gambarotti and Truscello reported oxidative conditions with sodium persulfate in water leading to short reaction times in the absence of acids (Scheme 38e) [123]. Water as the solvent was also subsequently used by J. Li's team but with catalytic ammonium persulfate under oxygen atmosphere and light assistance for the C-3 functionalization of 1-methylquinoxalin-2(1H)-one by DMF or DMAc (Scheme 38f) [124]. The teams of Han and Y. Zhang used the chelating properties of the 8-aminoquinolyl group for the regioselective $\mathrm{Ni}^{\mathrm{II}}$-catalyzed coupling of $\mathrm{N}$-(quinolin-8-yl)benzamides with DMAc, the use of di-tert-butyl peroxide as oxidant leading to selective reaction of a $\mathrm{C}\left(\mathrm{sp}^{3}\right)-\mathrm{H}$ bond adjacent to nitrogen of DMAc (Scheme 38(g $\left.\mathrm{g}_{1}\right)$ ) [125]. The Ni ${ }^{\mathrm{II}}$-catalyzed selective carbamoylation of 1,1-diphenylethene with DMAc under peroxide conditions in the presence of 2-methyl- $N$-(quinolin-8-yl)benzamide (Scheme 38( $\left(\mathrm{g}_{2}\right)$ ) revealed the radical character of 
the process [125]. Under $\mathrm{Cu}_{2} \mathrm{O}$ catalysis, oxidation of styrene with $\mathrm{Na}_{2} \mathrm{~S}_{2} \mathrm{O}_{8}$ in DMF provided a 3:1 mixture of $\mathrm{N}$-cinnamyl- $N$-methylformamide and $N, N$-dimethylcinnamamide (Scheme 38h) [126]. The $\mathrm{Ni}(\mathrm{cod})_{2} / t-\mathrm{BuOOH}$ association in DMAc mediated the selective carbamoylation of $\alpha, \alpha$-diaryl allylic alcohols while amidation was a competitive pathway in DMF (Scheme 38(i $\left.\mathrm{i}_{1}\right)$ ) [127]. Both pathways involve a radical 1,2-aryl migration succeeding to the reaction of the substrate with either $\mathbf{I}_{\mathbf{9}}$ (Scheme $38\left(\mathrm{i}_{2}\right)$ ) or $\mathbf{I}_{\mathbf{4}}$.

a.<smiles>CCc1ccncc1</smiles>

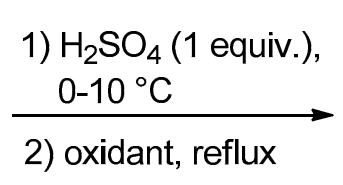<smiles>CCc1ccnc(Cl)c1</smiles><smiles>CN(C)C=[OH+]</smiles>
A $\mathrm{H}^{\prime} \mathrm{H}$

$t-\mathrm{BuOOH}$ (3 equiv.), $\mathrm{FeSO}_{4} \cdot \mathrm{H}_{2} \mathrm{O}$ (3 equiv.): $20 \%$ A/B ratio $t$-BuOOt-Bu (1 equiv.): $44 \% \quad 70: 30$ $\left(\mathrm{NH}_{4}\right)_{2} \mathrm{~S}_{2} \mathrm{O}_{8}$ (1 equiv.): $44 \% \quad 80: 20$<smiles>C=C(c1cc(CC)ccn1)N(C)C</smiles>
B $\stackrel{11}{O}$<smiles>[R]C(=O)N(C)[14CH2]c1ccc2nccnc2c1</smiles>

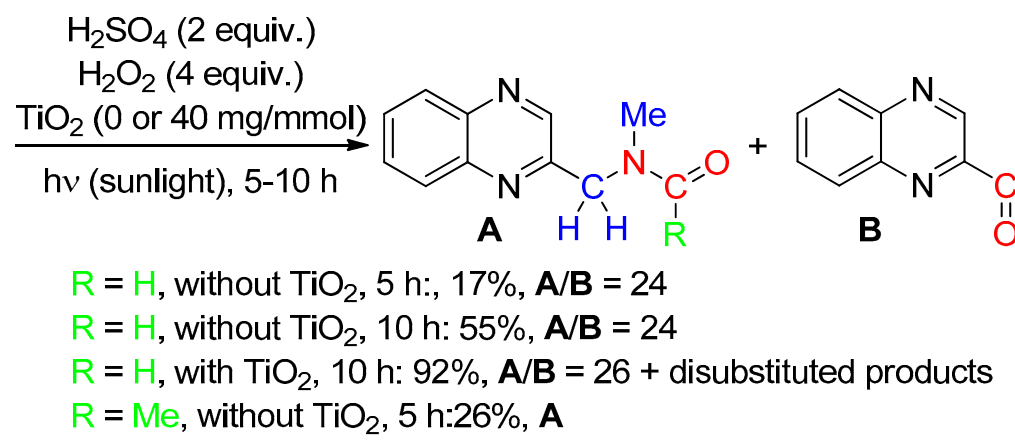

c.<smiles></smiles>

Eosin $\mathrm{Y}$ (0.1 equiv.)

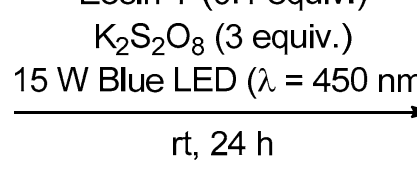<smiles>[R]C(=O)N(C)[C@H]([CH])c1nc2ccccc2s1</smiles><smiles></smiles>

$$
\begin{aligned}
R=H, 6 \text { examples } & \\
R^{1} & =H: \\
R^{1} & =6-\mathrm{NO}_{2}: \\
R^{1} & =6-\mathrm{Me}:
\end{aligned}
$$$$
\mathrm{R}^{1}=\mathrm{H}:
$$$$
\text { trace- } 79 \%
$$$$
68 \%\left(26 \%^{\mathrm{a}}\right)
$$$$
\text { trace }
$$$$
79 \%
$$

$\mathrm{R}=\mathrm{Me}, 12$ examples

$0-86 \%$

$\mathrm{R}^{1}=\mathrm{H}:$

$86 \%$

$\mathrm{R}^{1}=6-\mathrm{NO}_{2}$

trace

$\mathrm{R}^{1}=6-\mathrm{CN}$ :

$6 \%$

${ }^{a}$ In the absence of light.<smiles>CC(=O)N(C)N(C)C#Cc1ccc2nccc(C)c2c1</smiles><smiles>CC(=O)N(C)C(C)c1cc(C)c2ccccc2n1</smiles>

Scheme 38. Cont. 

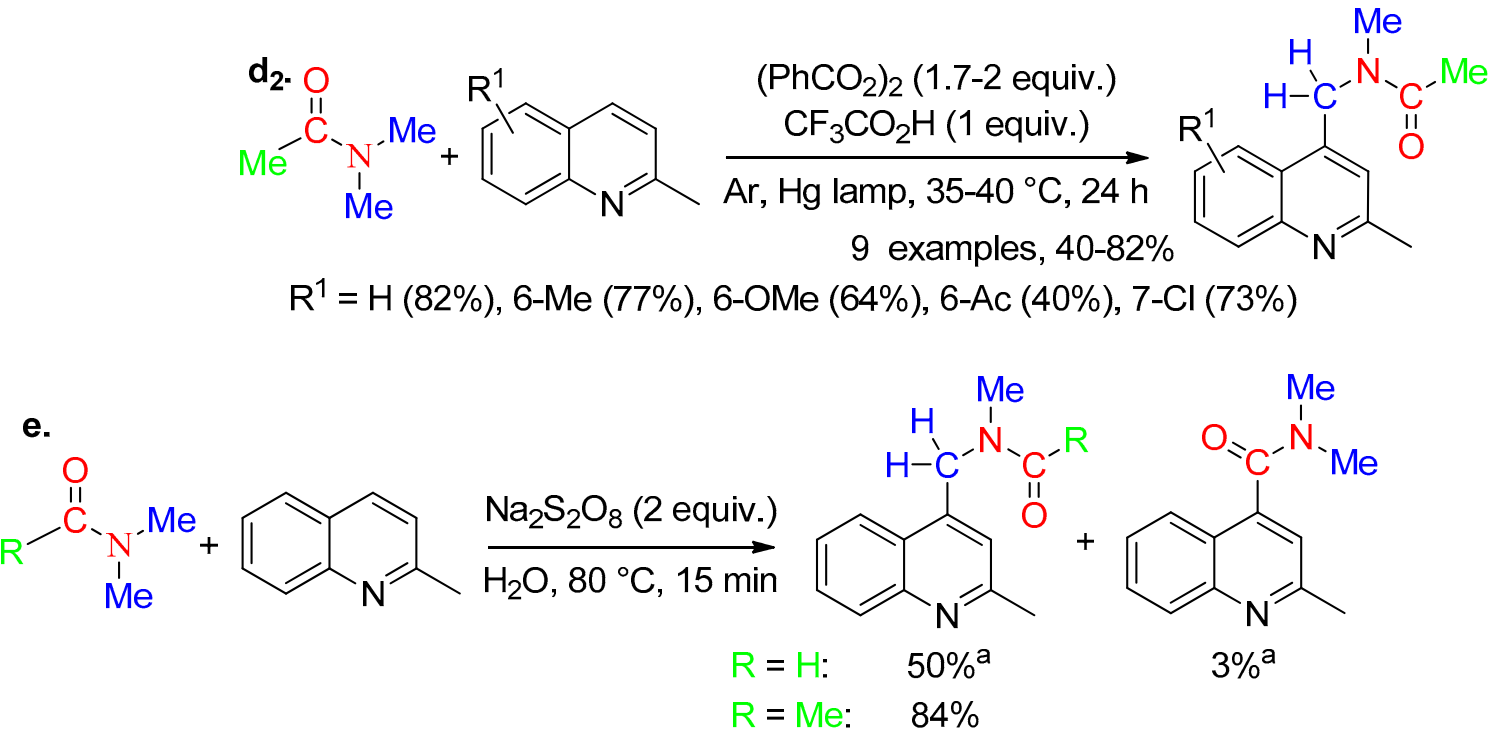

aplus $15 \%$ of a mixture of the two amides.
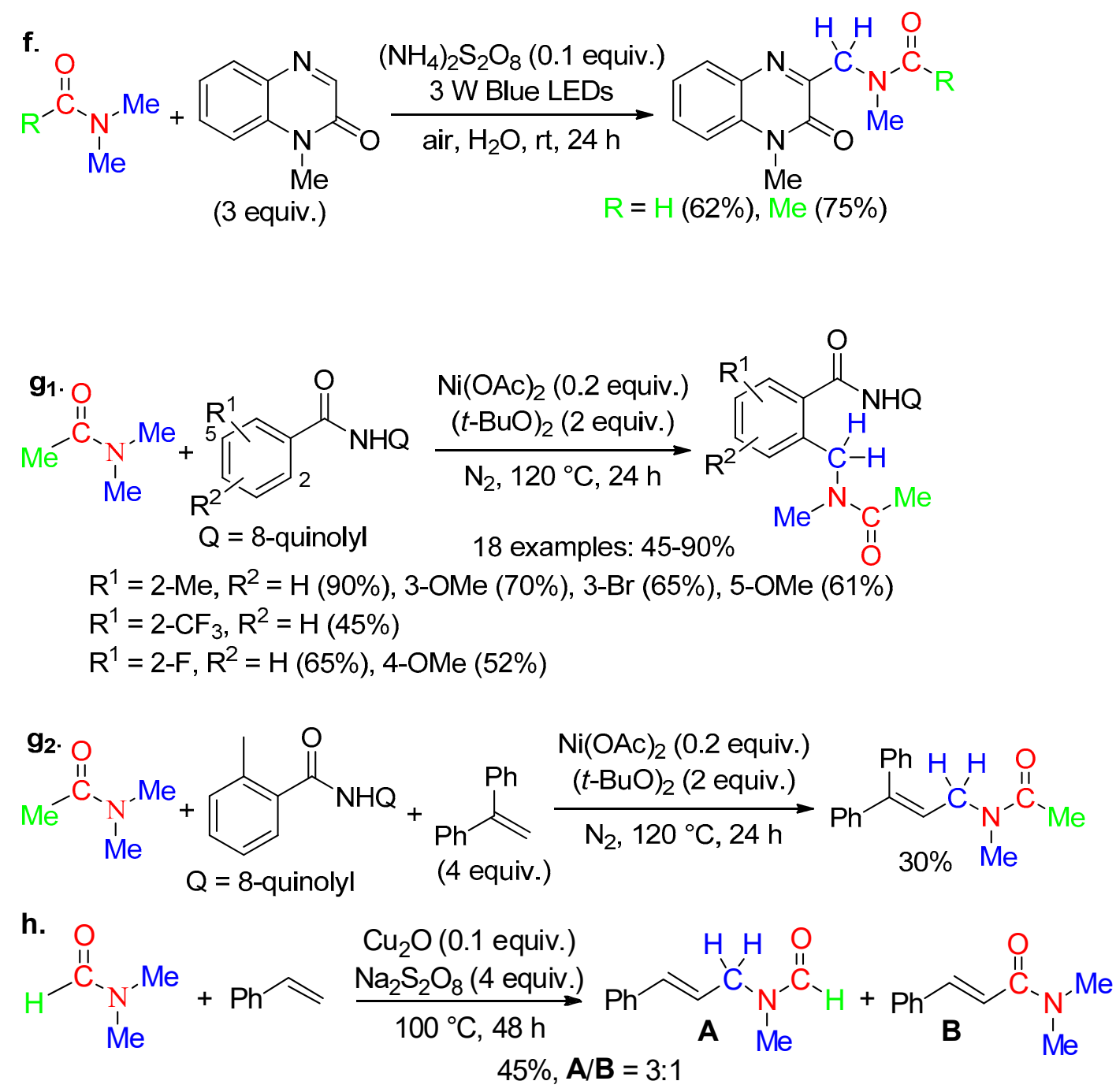


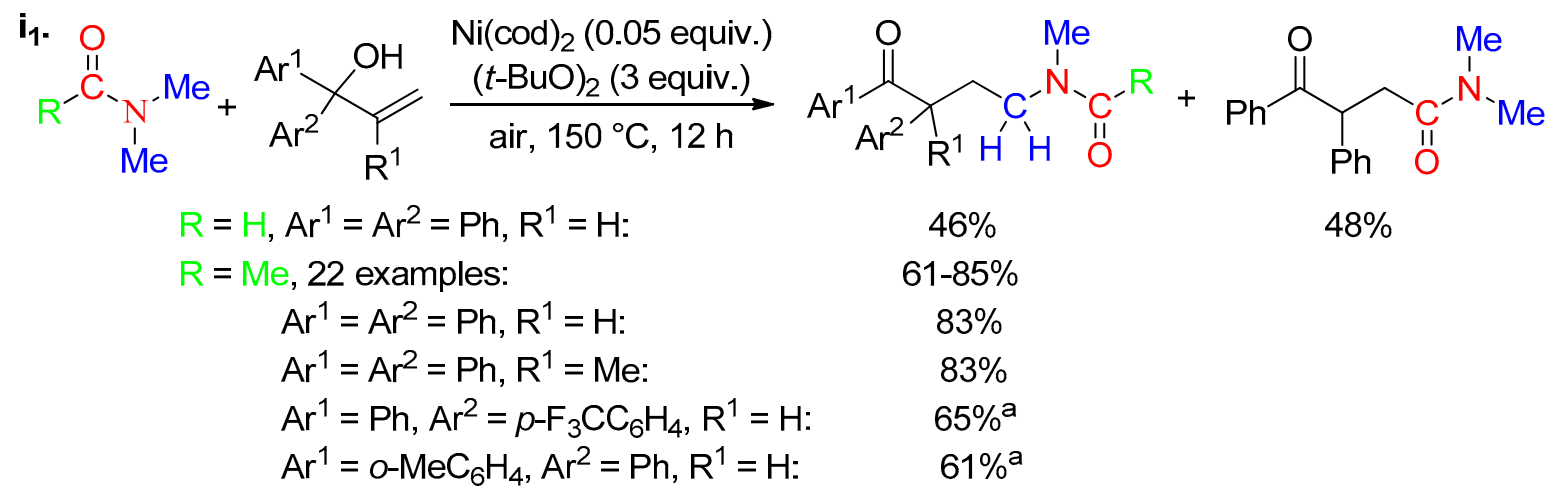

aYield of the major isomer.

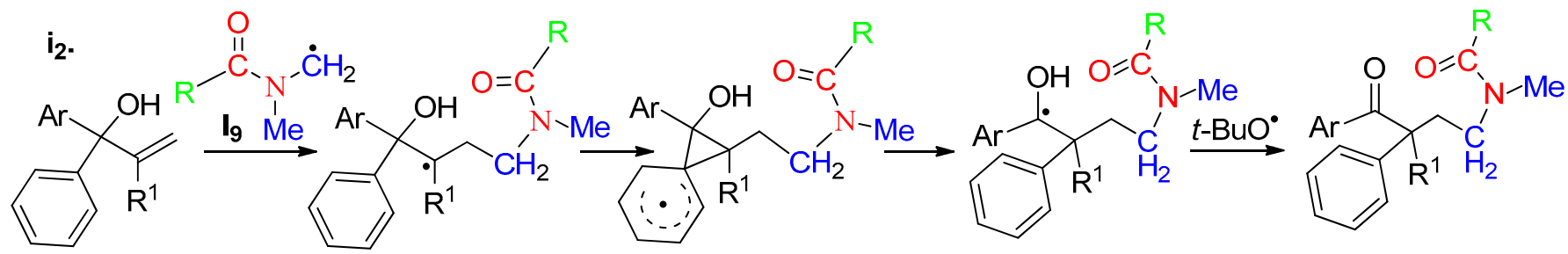

Scheme 38. Carbamoylation versus amidation.

The CuO-catalyzed reaction of cinnamic acids with DMAc and di-tert-butyl peroxide led to decarboxylative alkenylation giving the corresponding $N$-cinnamyl- $N$-methylace tamides (Scheme 39(a $\left.\mathrm{a}_{1}\right)$ ) while 3-methylbut-2-enoic acid afforded ( $\mathrm{N}$-methylacetamido) methyl 3-methylbut-2-enoate (Scheme 39( $\left.\mathrm{a}_{2}\right)$ ) [126]. Cross-coupling with the elimination of the sulfonyl or nitro group was also observed from the reaction of vinylsulfones, ((phenylethynyl)sulfonyl)benzene and $\beta$-nitrostyrenes using DM in the presence of either a diaryl ketone under visible-light irradiation (Scheme 39b) [128] or a peroxydisulfate (Scheme 39c) [129].

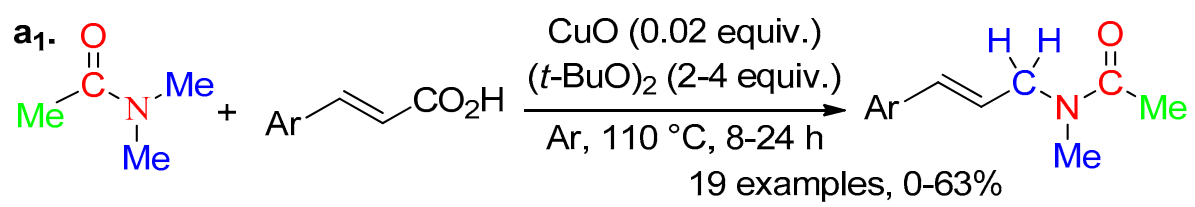

$\mathrm{Ar}=\mathrm{Ph}(63 \%), p-\mathrm{FC}_{6} \mathrm{H}_{4}(59 \%), p-\mathrm{MeOC}_{6} \mathrm{H}_{4}(58 \%), o-\mathrm{MeOC}_{6} \mathrm{H}_{4}(67 \%)$, $p-\mathrm{F}_{3} \mathrm{CC}_{6} \mathrm{H}_{4}$ (21\%), 2-furyl (71\%), 2-thienyl (52\%), 3-pyridinyl (0\%)
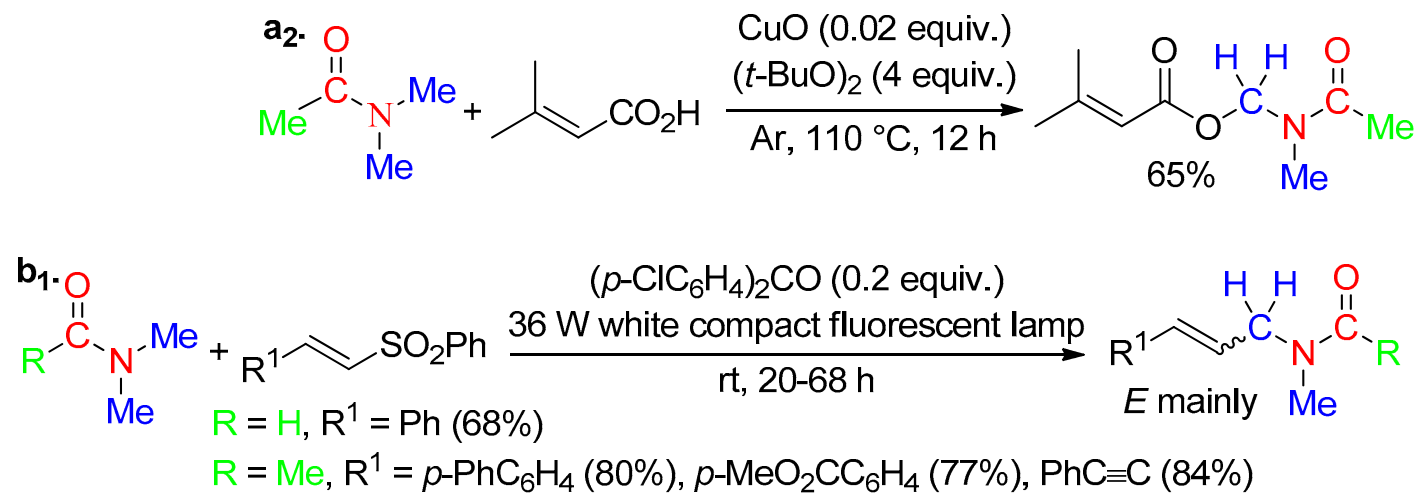

Scheme 39. Cont. 

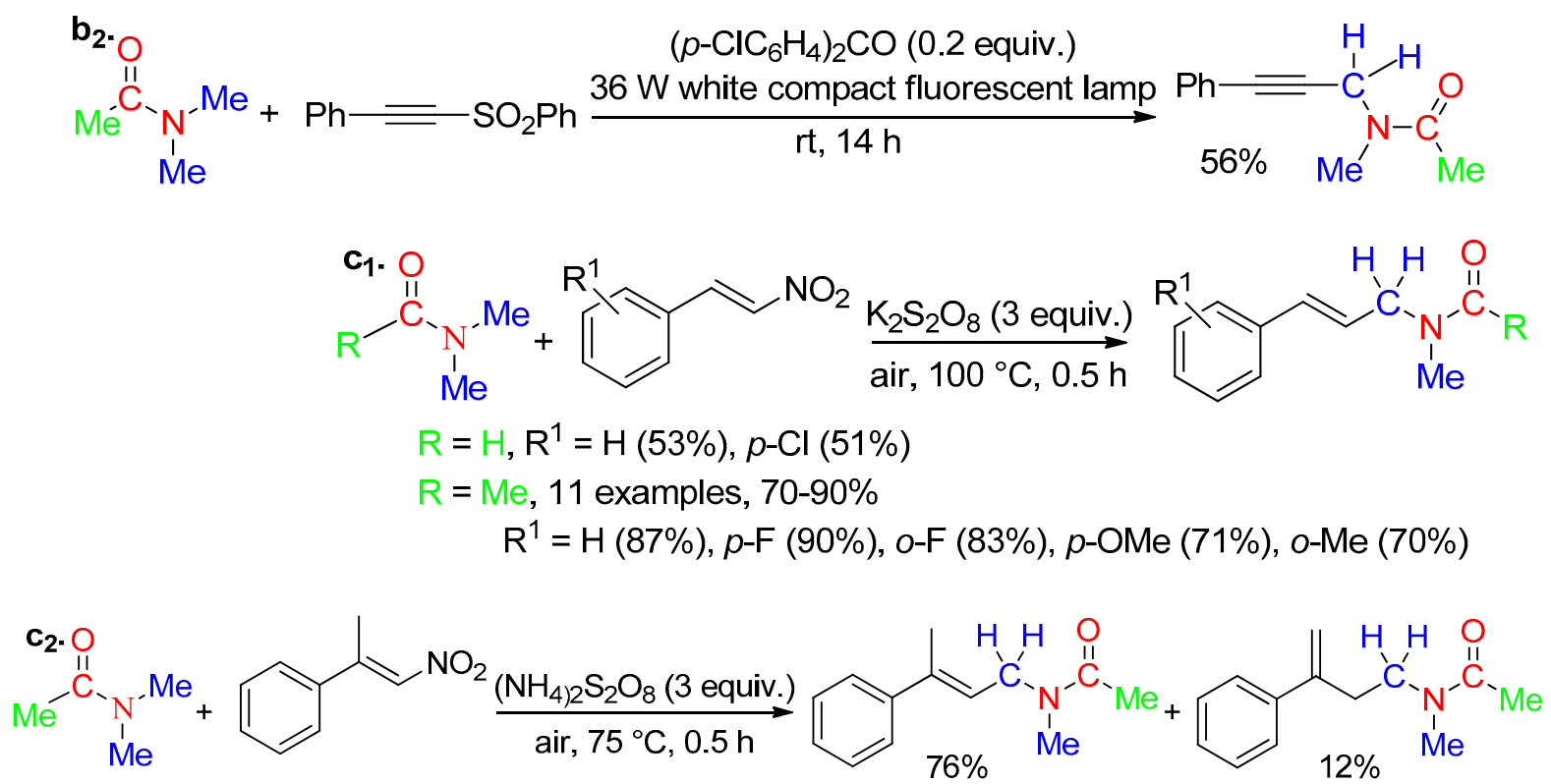

Scheme 39. Cross-coupling of $\alpha, \beta$-unsaturated acids, vinyl sulfones, ((phenylethynyl)sulfonyl)benzene and $\beta$-nitrostyrenes.

Treatment at $100{ }^{\circ} \mathrm{C}$ of styrene with $\mathrm{CuF}_{2}$ catalyst and $t-\mathrm{BuOOH}$ led to a complicated mixture in DMF while effective production of $\mathrm{N}$-methyl- $\mathrm{N}$-(3-oxo-3-phenylpropyl)acetamide arose in DMAc (Scheme 40) [126]. Various vinylarenes undergo such an oxyalkylation (Scheme 40).

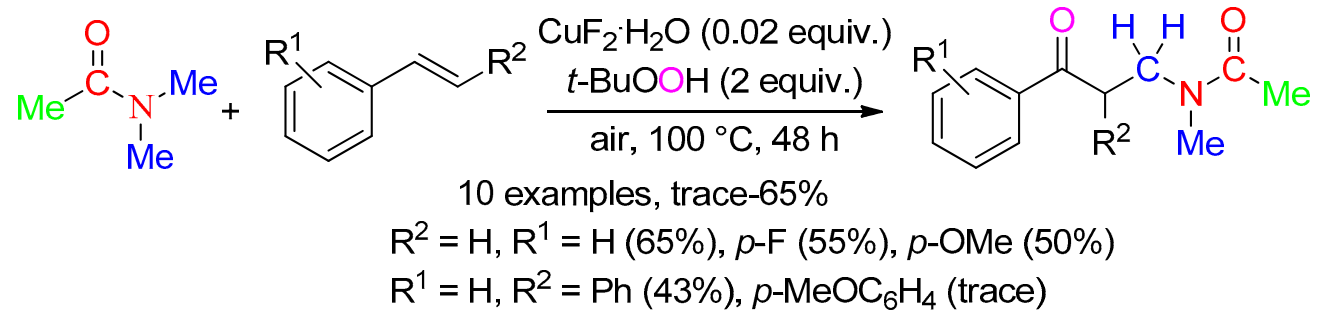

Scheme 40. Oxyalkylation of styrenes.

The above reactions involve radical intermediates $\mathbf{I}_{\mathbf{9}}$ and/or $\mathbf{I}_{\mathbf{4}}$.

Borylation [130-132], silylation [133], and amidation [134] of N-adjacent C-H bond of DMAc have been achieved with bis(pinacolato)diboron and Rh or Ir catalysis (Scheme 41a,b), triethylsilyl hydride, Ru catalysis, and tert-butylethylene as the hydrogen acceptor (Scheme 41c), and $N$-haloimides under blue light irradiation (Scheme 41d). The transition-metal catalysis could involve the $\mathrm{C}\left(\mathrm{sp}^{3}\right)-\mathrm{H}$ bond oxidative addition to the metal center $[135,136]$ while the photochemical conditions promote the formation of radical $\mathbf{I}_{9}$ [134]. 

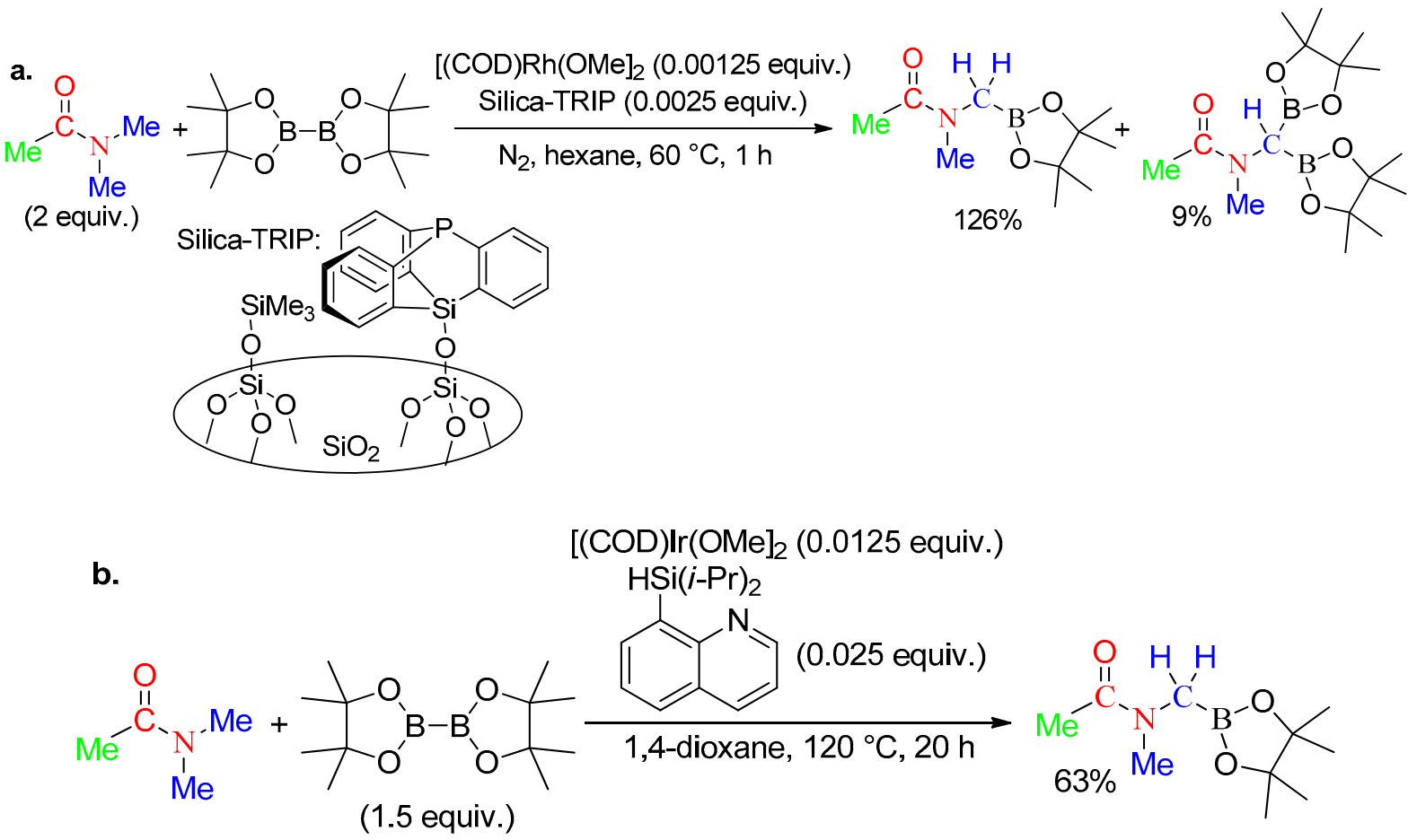

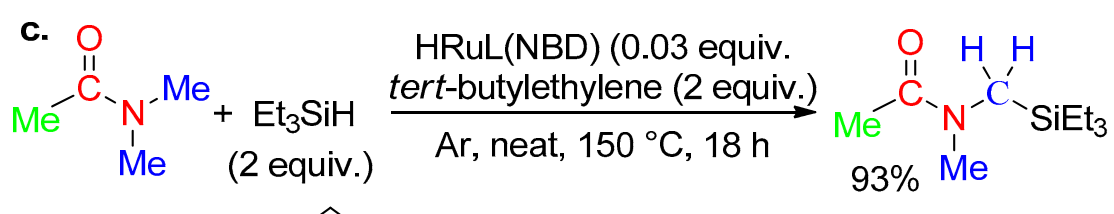

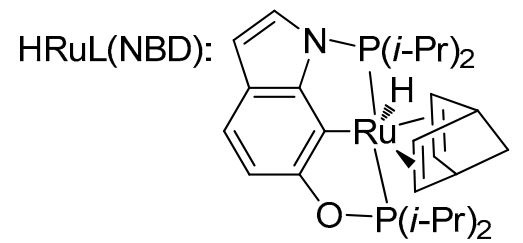

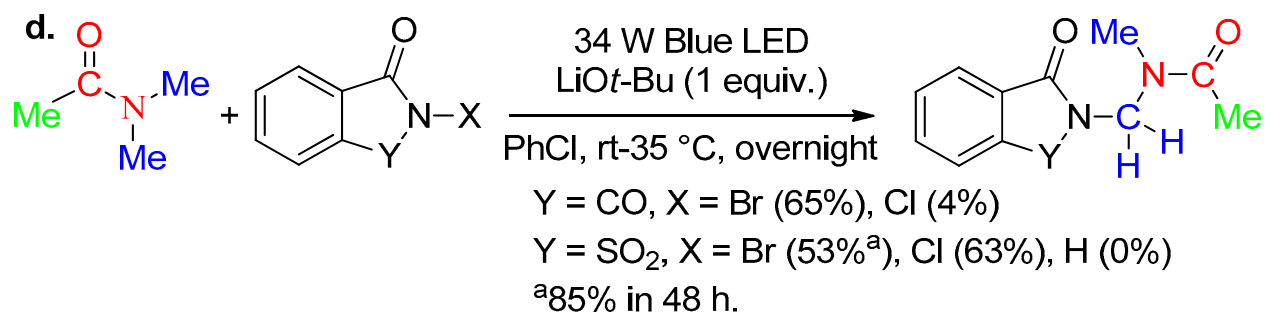

Scheme 41. Borylation, silylation, and amidation of $\mathrm{N}$-adjacent $\mathrm{C}-\mathrm{H}$ bond of DMAc.

\section{6. $\mathrm{RC}-\mathrm{ONMe}$ Fragment}

Under AgOTf catalysis at $130^{\circ} \mathrm{C}$ in $\mathrm{DM}$, cyclopropenones underwent ring opening producing 5-amino-2-furanones (Scheme 42) [137]. Matsuda and co-workers proposed a reaction arising from the addition of the oxygen atom of DM to the Ag-coordinated carbonyl group of the cyclopropenone. 


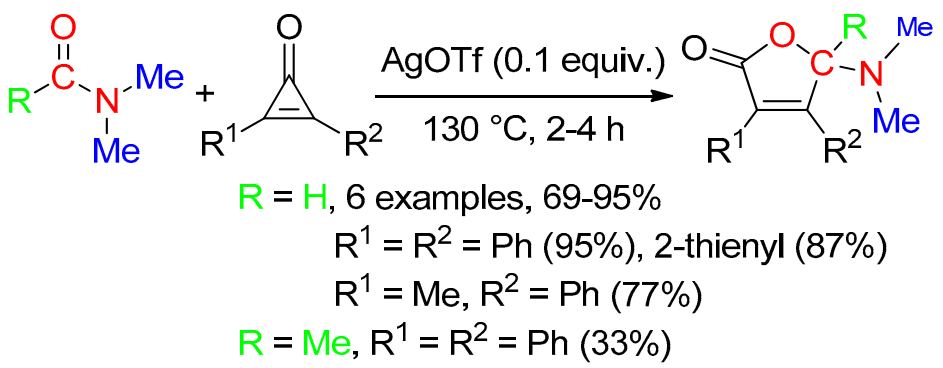

Scheme 42. [3+2] Annulation.

\section{7. $\mathrm{H}_{1,2} \mathrm{CC}=\mathrm{ONMe}_{2}$ Fragment, or $\mathrm{H}$ and $\mathrm{H}_{1,2} \mathrm{CC}=\mathrm{ONMe}_{2}$ Fragments}

$\mathrm{N}, \mathrm{N}$-dimethyl-4,4-diarylbutanamides have been synthetized at room temperature from base-mediated addition of DMAc on 1,1-diarylethylenes (Scheme 43) [138]. According to a previous report of Kobayashi's team [139], the anionic intermediate produced from the addition of enolate $\mathbf{I}_{\mathbf{1 0}}$ to the substrate is protonated with an $\mathrm{H}$ of the Me moiety of DMAc.

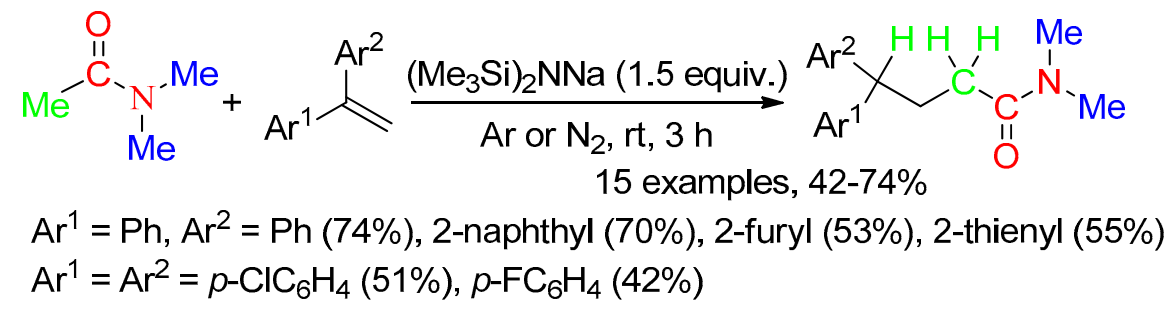

Scheme 43. Base-promoted addition of DMAc.

$\mathrm{Mn}, \mathrm{Rh}$, or Ni catalyst associated with $t$-BuOK performed effective C-alkylation of DMAc with primary alcohols (Scheme 44a-f). Hydrogen transfers are involved but plausible hydrogen exchange between alcohol and DMAc led to uncertainty about the hydrogen origin in the final product. The reactions occur via transition-metal-catalyzed oxidation of the alcohol $\left(\mathrm{R}^{\prime} \mathrm{CH}_{2} \mathrm{OH}\right)$ followed by base-mediated condensation with DMAc leading to the corresponding $\alpha, \beta$-unsaturated amide- $\mathrm{R}^{\prime} \mathrm{CH}=\mathrm{CHCO}\left(\mathrm{NMe}_{2}\right)$ - which was sometimes isolated as a by-product (Scheme 44a,d,e). According to the teams of Milstein [140] and Gupta and Balaraman [141], hydrogenation of the latter with $\mathrm{H}_{2}$ formed from alcohol oxidation provides the final product (Scheme 44a,b), whereas experiments with $\mathrm{PhCD}_{2} \mathrm{OH}$ led the teams of Rueping and El-Sepelgy to assume that the Mn-catalyzed alcohol oxidation produced the hydrogenated species $\mathbf{I}_{\mathbf{M n}}$ [142]. Subsequent insertion of the $\mathrm{C}=\mathrm{C}$ bond into the $\mathrm{Mn}-\mathrm{H}$ bond followed by $\mathrm{H}$ transfer would provide the product (Scheme 44c). According to Chen's team (Scheme 44d), the hydridorhodium species issued from Rh-catalyzed dehydrogenation of the alcohol adds to $\mathrm{R}^{\prime} \mathrm{CH}=\mathrm{CHCO}\left(\mathrm{NMe}_{2}\right)$ affording an oxo- $\pi$-allylrhodium complex [143]. The reaction of the latter with $\mathrm{R}^{\prime} \mathrm{CH}_{2} \mathrm{OH}$ would deliver the product and the $\mathrm{Rh}$ alcoholate $\mathrm{RhOCH}_{2} \mathrm{OR}^{\prime}$ which would be the active catalytic species. Madhu, Balaraman, and their co-workers (Scheme 44e) performed a deuterium labeling experiment with $p-\mathrm{ClC}_{6} \mathrm{H}_{4} \mathrm{CD}_{2} \mathrm{OD}$ which led to a 16:36:48 mixture of $\mathrm{D}_{0}, \mathrm{D}_{1}$, and $\mathrm{D}_{2}$ 3-( $p$-chlorophenyl)$\mathrm{N}, \mathrm{N}$-dimethylpropanamide [144]. The formation of the $\mathrm{D}_{0}$ product "is in agreement with the microreversibility of the initial alcohol dehydrogenation process" [144]. Yang, Zhou, Tang, and their co-workers (Scheme 44f) carried out labeling experiments with $\mathrm{PhCD}_{2} \mathrm{OH}$ and $t$-BuOD as an additive, but to ascribe the origin of hydrogens in $\alpha$ - and $\beta$-positions was also tedious [145]. It seems remarkable that the above Ni-catalyzed conditions led to the alcohol oxidation rather than to the $\mathrm{C}-\mathrm{N}$ bond cleavage [33] of DMAc.

Madsen and Azizi disclosed a transition-metal-free C-alkylation of DMAc with benzylic alcohols, through a reaction mediated by $t$-BuOK or $t$-BuONa [146]. Use of 2 equiv. of the base provided the saturated amide in fair yields while lower amounts led to a mixture of the saturated and unsaturated amides (Scheme $44 \mathrm{~g}$ ). No reaction occurred with aliphatic 
alcohols such as hexan-1-ol and heptan-1-ol. According to the authors, the reaction occurs thanks to the dual role-base and radical initiator - of both bases (that differs from an above hypothesis, see Section 14 [95]) which initiates the formation of radical anion $\mathrm{ArCH}^{\circ} \mathrm{O}^{\ominus}$ from $\mathrm{ArCH}_{2} \mathrm{OH}$. A subsequent radical chain pathway involving DMAc affords $\mathrm{ArCH}=\mathrm{CH}$ $\mathrm{CO}\left(\mathrm{NMe}_{2}\right)$ and $\mathbf{I}_{8}$. Single-electron transfer from $\mathbf{I}_{8}$ to the unsaturated amide followed by reaction with $\mathrm{ArCH}_{2} \mathrm{OH}$ provides the product and regenerates $\mathrm{ArCH}^{\cdot} \mathrm{O}^{\ominus}$. Experiments with $\mathrm{PhCD}_{2} \mathrm{OH}$ did not allow to propose hydrogen distribution more accurately than the one shown in Scheme 44g.
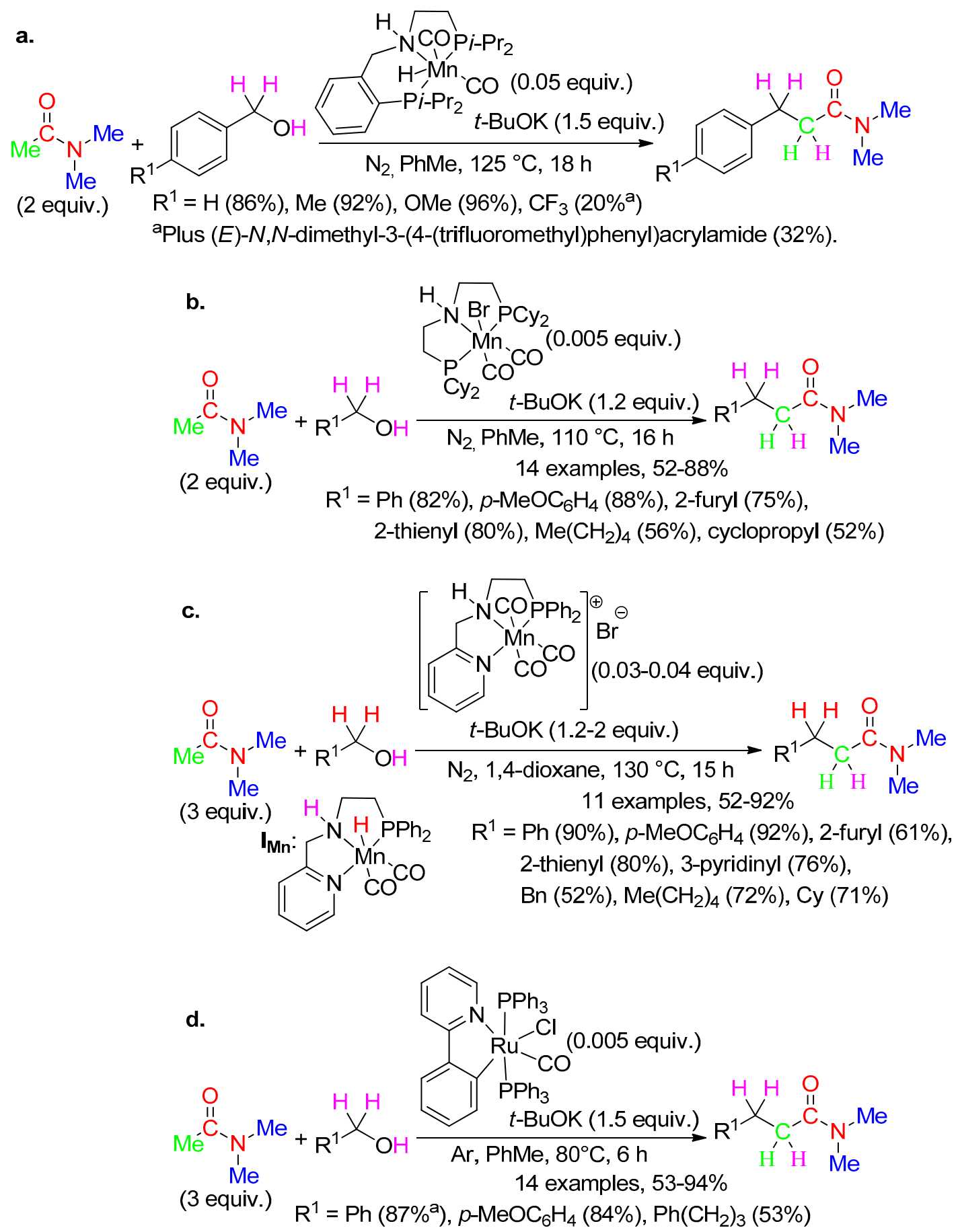

aixture (32:68) of $\mathrm{N}, \mathrm{N}$-dimethyl-3-phenylpropanamide and $\mathrm{N}, \mathrm{N}$-dimethylcinnamamide under $\mathrm{O}_{2}$. 


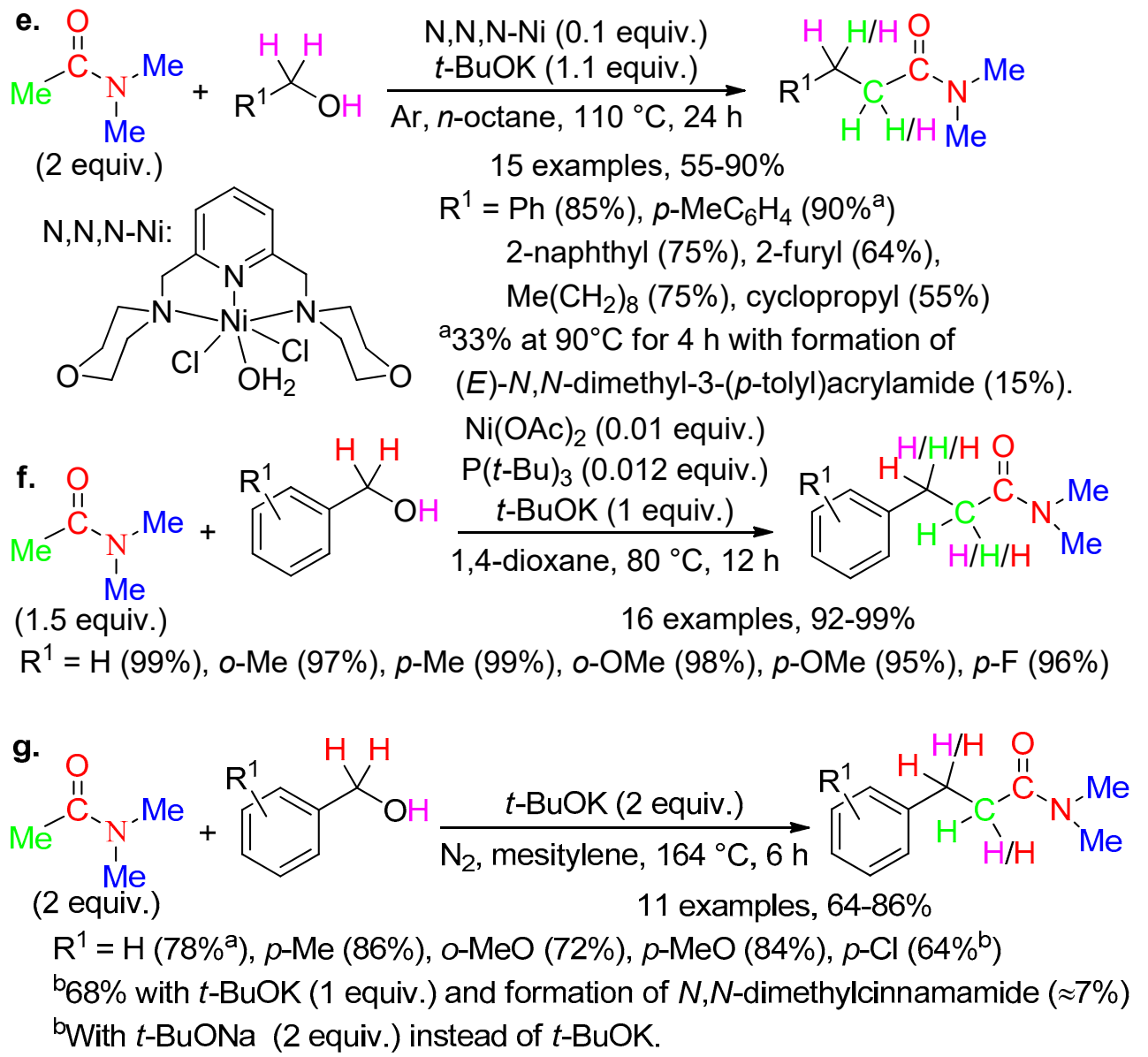

Scheme 44. C-Alkylation of DMAc.

The $\mathrm{Ni}^{\mathrm{II}}$-catalyzed reaction of $\mathrm{N}$-(quinolin-8-yl)benzamides with DMAc using $\mathrm{Ag}_{2} \mathrm{SO}_{4}$ and $\mathrm{NaOCO} t$-Bu (Scheme 45$)$ instead of $(t-\mathrm{BuO})_{2}$ (Scheme $\left.38\left(\mathrm{~g}_{1}\right)\right)$ favored the formation of 2-(2-(dimethylamino)-2-oxoethyl)- $N$-(quinolin-8-yl)benzamides rather than that of 2-((Nmethylacetamido)methyl)- $\mathrm{N}$-(quinolin-8-yl) [125]. The reactions disclosed in Scheme 38(g $\left.\mathrm{g}_{1}\right)$ and Scheme 45 differ strongly from that previously reported under oxygen and $\mathrm{Ni} / \mathrm{Cu}$ catalysis which provided 2-(quinolin-8-yl)isoindoline-1,3-diones via carbonylation using $\mathrm{DM}$ as the carbon source of carbonyl group [2,3,147].

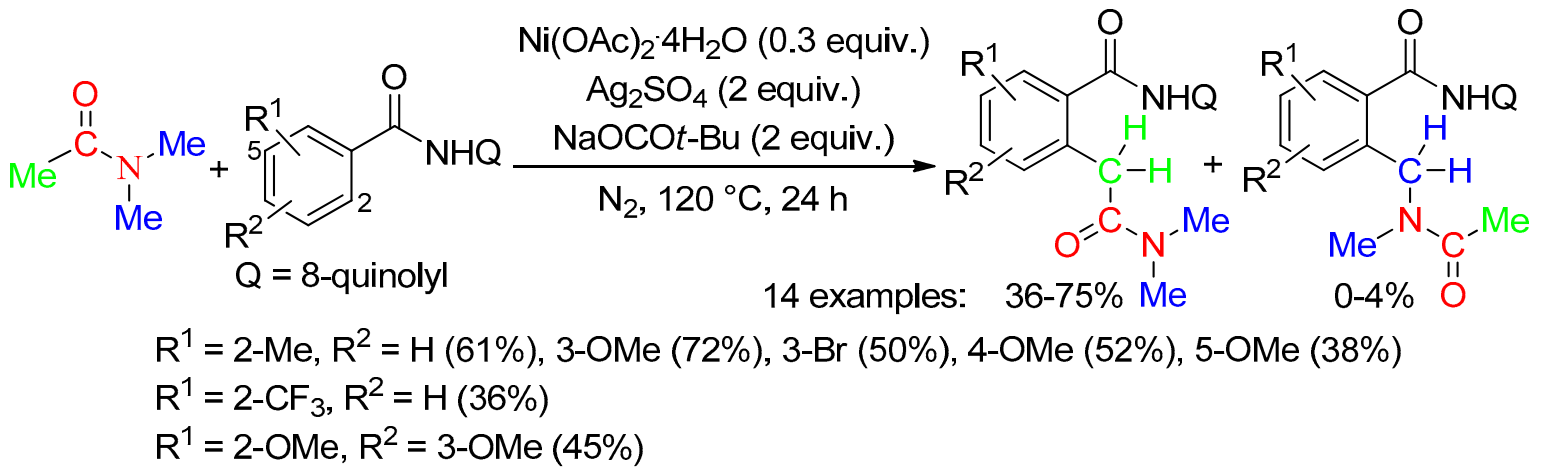

Scheme 45. $\mathrm{C}\left(\mathrm{sp}^{2}\right)-\mathrm{H} / \mathrm{C}\left(\mathrm{sp}^{3}\right)-\mathrm{H}$ rather than $\mathrm{C}\left(\mathrm{sp}^{2}\right)-\mathrm{H} / \mathrm{C}\left(\mathrm{sp}^{3}\right)-\mathrm{H}$ cross-coupling.

Concomitant addition of Grignard reagents and TMSCN to DMF leading to $\alpha$-amino nitriles was promoted with $\mathrm{Ti}(\mathrm{O} i-\mathrm{Pr})_{4}$ catalysis (Scheme $\left.46\left(\mathrm{a}_{1}\right)\right)$ through, according to Lannou/Sorin's team, the addition of the Grignard reagent, transmetallation followed by reaction with TMSCN as depicted in Scheme 46( $\left.\mathrm{a}_{2}\right)$ [148]. 


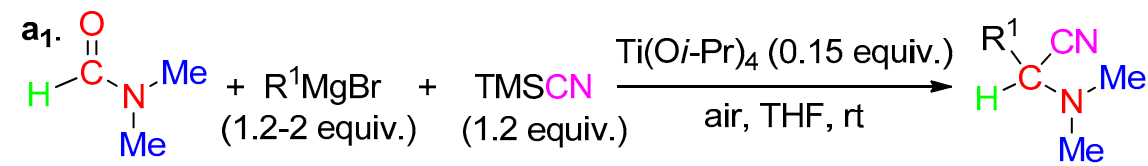
$\mathrm{R}^{1}=\mathrm{Ph}(88 \%), \mathrm{p}_{\mathrm{ClC}} \mathrm{H}_{4}$ (92\%), Bn (84\%), c-pentyl (73\%), c-hexyl (90\%)

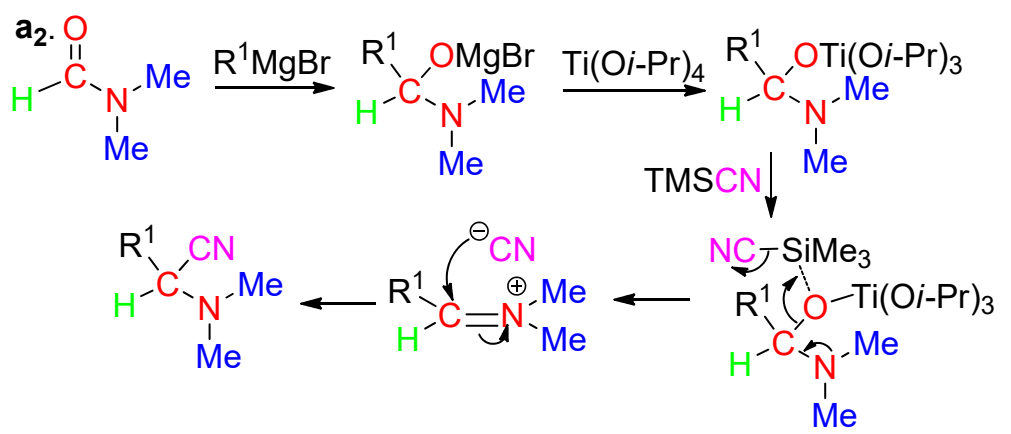

Scheme 46. C-Alkylative cyanation of DMF.

\section{8. $R C$ and $O$ Fragments}

Various reactions implicating the insertion of arynes into the $\mathrm{N}-\mathrm{C}$ or $\mathrm{C}=\mathrm{O}$ bonds of amides have been reported [7]. In the presence of both $\mathrm{KF}$ and $\mathrm{K}_{2} \mathrm{CO}_{3}$, 2-(trimethylsilyl)phenyl trifluoromethanesulfonate reacts with DMF and either $p$-toluenesulfonyl chloride or 2bromoacetophenone to provide 2-formylphenyl benzenesulfonate (Scheme 47a) [149] or benzofuran-2-yl(phenyl)methanone (Scheme 47b) [150], respectively. Both reactions involve benzoxetene $\mathbf{I}_{\mathbf{B O}}$ or ortho-quinone methide $\mathbf{I}_{\mathbf{Q M}}$ obtained via KF-mediated formation of benzyne, and subsequent insertion into the $\mathrm{C}=\mathrm{O}$ bond of DMF (Scheme $47 \mathrm{c}$ ). The addition of the sulfonate followed by aqueous work-up affords 2-formylphenyl benzenesulfonate. The bicyclic compound is produced from addition to bromoacetophenone followed by base-mediated cyclization and aromatization.
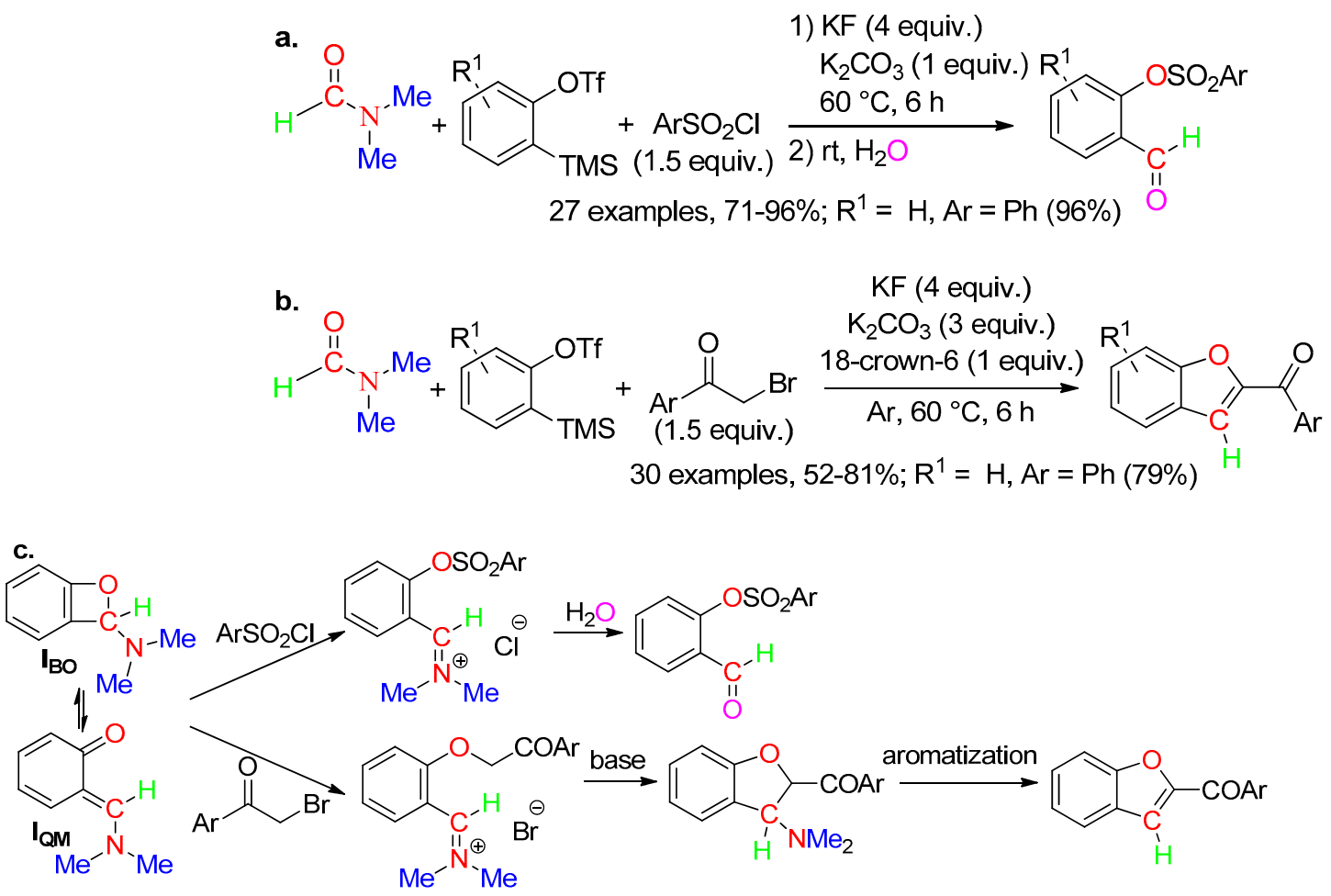

Scheme 47. [2 + 2] Cycloadditions. 


\section{HCO and C-O Fragments}

Recently, the Qi/Liu team proposed a Sm/CuI-mediated reaction between DMF, aryl halides, and esters or diesters leading to functionalized diaryl methanols (Scheme 48) [151]. The mechanism is unclear. Formylation of ArX following by some coupling between two molecules of $\mathrm{ArCHO}$ and the ester could be involved [151].

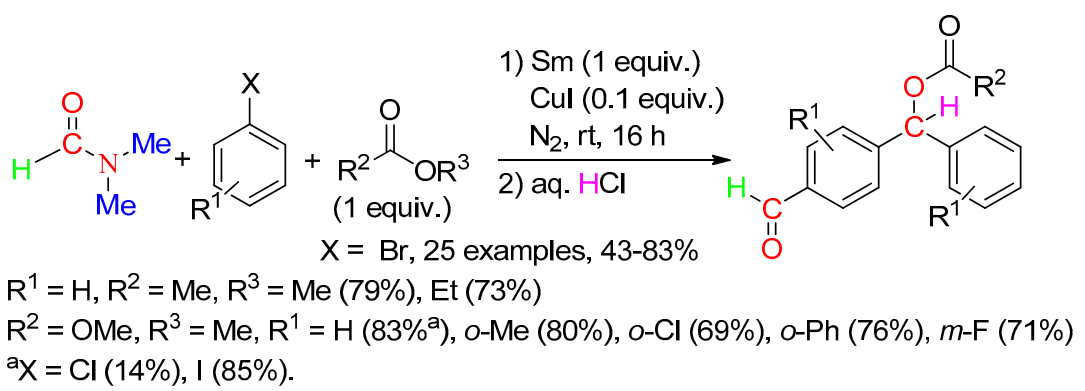

Scheme 48. Diarylmethanol skeletons via three-component reactions.

\section{0. $\mathrm{H}$ and $\mathrm{NMe}_{2}$ Fragments}

The Leuckart-type reaction between wet DMF and aldehydes or ketones arose at 140-160 ${ }^{\circ} \mathrm{C}$ under catalysis with various Lewis [152-154] or Brønsted [93] acids (Scheme 49). The use of DCON $\left(\mathrm{CD}_{3}\right)_{2}$ led to the $d_{7}$-reductive amination product $[93,152]$. The acidic conditions cause the formation of $\mathrm{HCOOH}$ and $\mathrm{HNMe}_{2}$ from $\mathrm{HCONMe}_{2}$ and $\mathrm{H}_{2} \mathrm{O}$. The subsequent condensation of the primary amine with the substrate $\left(R^{1} R^{2} C=O\right)$ generates the iminium cation $\mathrm{R}^{1} \mathrm{R}^{2} \mathrm{C}=\mathrm{N}^{\oplus} \mathrm{Me}_{2}$ which undergoes reduction with $\mathrm{HCOOH}$ leading to $\mathrm{R}^{1} \mathrm{R}^{2} \mathrm{CH}\left(\mathrm{NMe}_{2}\right)$.

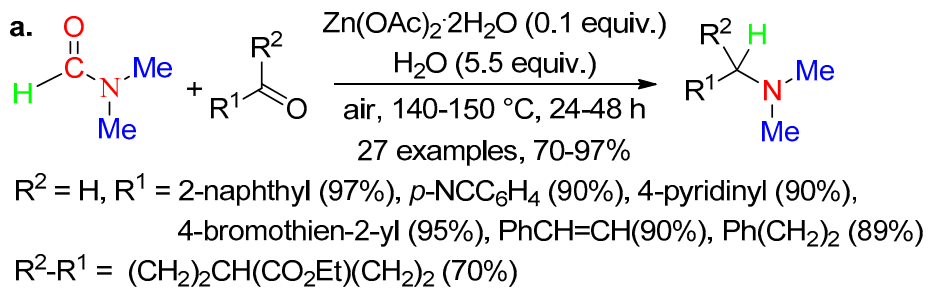

b.
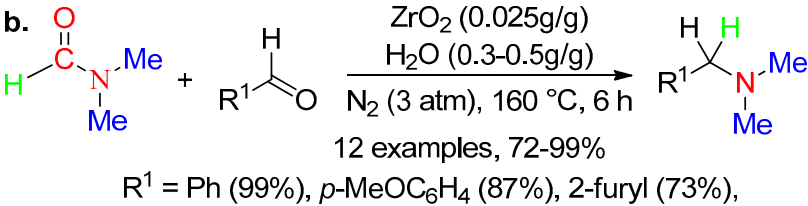

$\mathrm{Ph}\left(\mathrm{CH}_{2}\right)_{2}(72 \%), \mathrm{Me}\left(\mathrm{CH}_{2}\right)_{4}(98 \%)$

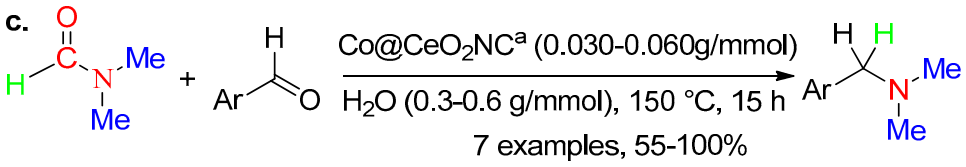

$\mathrm{Ar}=\mathrm{Ph}(100 \%), o-\mathrm{HOC}_{6} \mathrm{H}_{4}(95 \%), p-\mathrm{NCC}_{6} \mathrm{H}_{4}(92 \%), 2$-thionyl (55\%)

ananocatalyst obtained from aqueous $\left(\mathrm{NH}_{4}\right)_{2} \mathrm{Ce}\left(\mathrm{NO}_{3}\right)_{6}$ and $\mathrm{Co}\left(\mathrm{NO}_{3}\right)_{2}$ using coprecipitation method

$$
\begin{aligned}
& \text { d. } \mathrm{O} \quad \mathrm{R}^{2} \mathrm{TfOH}(0.05 \text { equiv.) }
\end{aligned}
$$

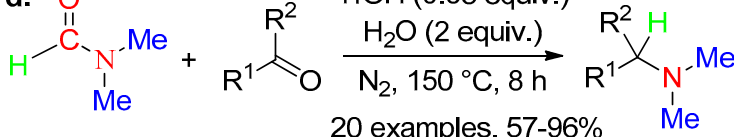

$$
\begin{aligned}
& \mathrm{R}^{2}=\mathrm{H}, \mathrm{R}^{1}=\mathrm{Ph} \text { (96\%), 2-benzothiophenyl (81\%), } \\
& \mathrm{PhCH}=\mathrm{CH}(81 \%), \mathrm{Me}\left(\mathrm{CH}_{2}\right)_{6}(77 \%) \\
& \mathrm{R}^{2}=\mathrm{Me}, \mathrm{R}^{1}=2 \text {-naphthyl }(71 \%), m-\mathrm{MeOC}_{6} \mathrm{H}_{4}(60 \%)
\end{aligned}
$$

Scheme 49. Reductive amination of aldehydes and ketones. 


\section{1. $\mathrm{CH}_{1,2}$ andNMe 2 Fragments}

While Marinelli's team isolated (1H-indol-2-yl)(phenyl)methanone in 60\% yield from microwave heating $\left(140{ }^{\circ} \mathrm{C}\right)$ in DMF of o-phenylethynyl aniline in the presence of 0.2 equiv. of $\mathrm{CuCl}$ (Scheme 50a) [155], Lin and co-workers subsequently obtained (4-(dimethylamino) quinolin-3-yl)(phenyl)methanone in $71 \%$ yield from the reaction at $120{ }^{\circ} \mathrm{C}$ of the same substrate, in the same solvent with the same amount of $\mathrm{CuCl}$, but under oxygen atmosphere, the yield increased to $82 \%$ with DMSO as the additive (Scheme 50b) [156]. As Marinelli's report was not cited by Lin's team, no explanation of the reactivity difference was provided. The discrepancy between the two reports is plausibly due to the oxidation medium of the second paper. According to DFT calculations reported in the first paper, activation of the triple bond by coordination to a $\mathrm{Cu}^{\mathrm{I}}(\mathrm{DMF})$ complex promotes intermolecular hydroamination, with preservation of the oxidation state of the catalyst [155]. Lin and co-workers assumed that oxygen oxidizes $\mathrm{Cu}^{\mathrm{I}}$ into $\mathrm{Cu}^{\mathrm{II}}$ [156], a reaction probably promoted by DMSO $[157,158]$. This redox system is associated with the thermal decomposition of DMF, a decisive step of the proposed mechanism, which agrees with labeling experiments using DCON $\left(\mathrm{CD}_{3}\right)_{2}$ and $\mathrm{H}^{13} \mathrm{CON}\left(\mathrm{CH}_{3}\right)_{2}$. Scheme $50 \mathrm{c}$ slightly differs from that proposed by the authors. The pivotal role of the experimental conditions on the $\mathrm{Cu}$-catalyzed reaction of $o$-phenylethynyl aniline has to be highlighted. Indeed, Lin's team previously reported the production of 2-phenyl- $1 \mathrm{H}$-indole-3-carbaldehyde from $\mathrm{o}$ phenylethynyl aniline under $\mathrm{Cu}\left(\mathrm{OCOCF}_{3}\right)_{2} \cdot \mathrm{xH}_{2} \mathrm{O}$ catalysis and $\mathrm{O}_{2}$ atmosphere in DMF at $120{ }^{\circ} \mathrm{C}$ (Scheme $\left.3\left(b_{1}\right)\right)$ [20], that is under experimental conditions very close to those they subsequently used (Scheme 50b) [156] but the striking reactivity difference was again neither explained nor pointed out by the authors.

Hajira's team disclosed the $\mathrm{Cu}^{\mathrm{II}}$-catalyzed aminomethylation of imidazopyridines with DMF and $t$-BuOOH (Scheme 51) [159]. According to the authors, the reaction arises via addition to the substrate of $\mathrm{H}_{2} \mathrm{C}=\mathrm{N}^{\oplus} \mathrm{Me}_{2}$, formed as depicted in Scheme 50c but using $t$ - $\mathrm{BuOOH}$ as the oxidant.

a.

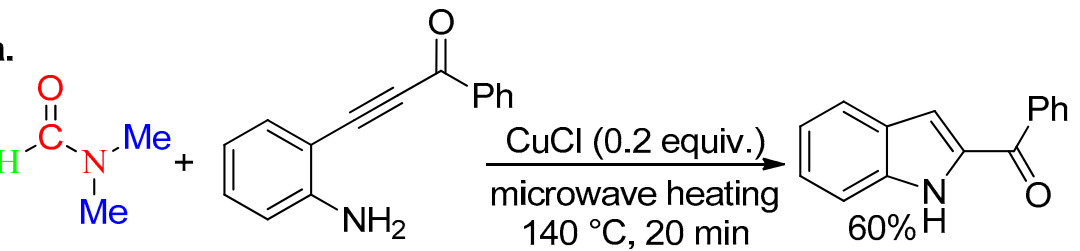

b.

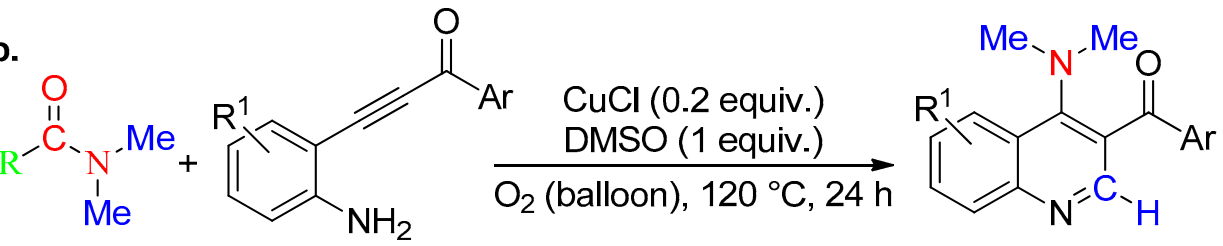

$\mathrm{R}=\mathrm{H}, 20$ examples, $0-82 \%$

$\mathrm{R}^{1}=\mathrm{H}, \mathrm{Ar}=\mathrm{Ph}\left(82 \%^{\mathrm{a}}\right)$, 2-furyl (52\%), 1-naphthyl (48\%)

$\mathrm{Ar}=\mathrm{Ph}, \mathrm{R}^{1}=5-\mathrm{Me}$ (74\%), 5-Br (54\%), 5- $\mathrm{CO}_{2} \mathrm{Et}$ (trace), 3-SMe (0\%)

$\mathrm{R}=\mathrm{Me}, \mathrm{R}^{1}=\mathrm{H}, \mathrm{Ar}=\mathrm{Ph}(31 \%)$

${ }^{a} 71 \%$ in the absence of DMSO.

Scheme 50. Cont. 


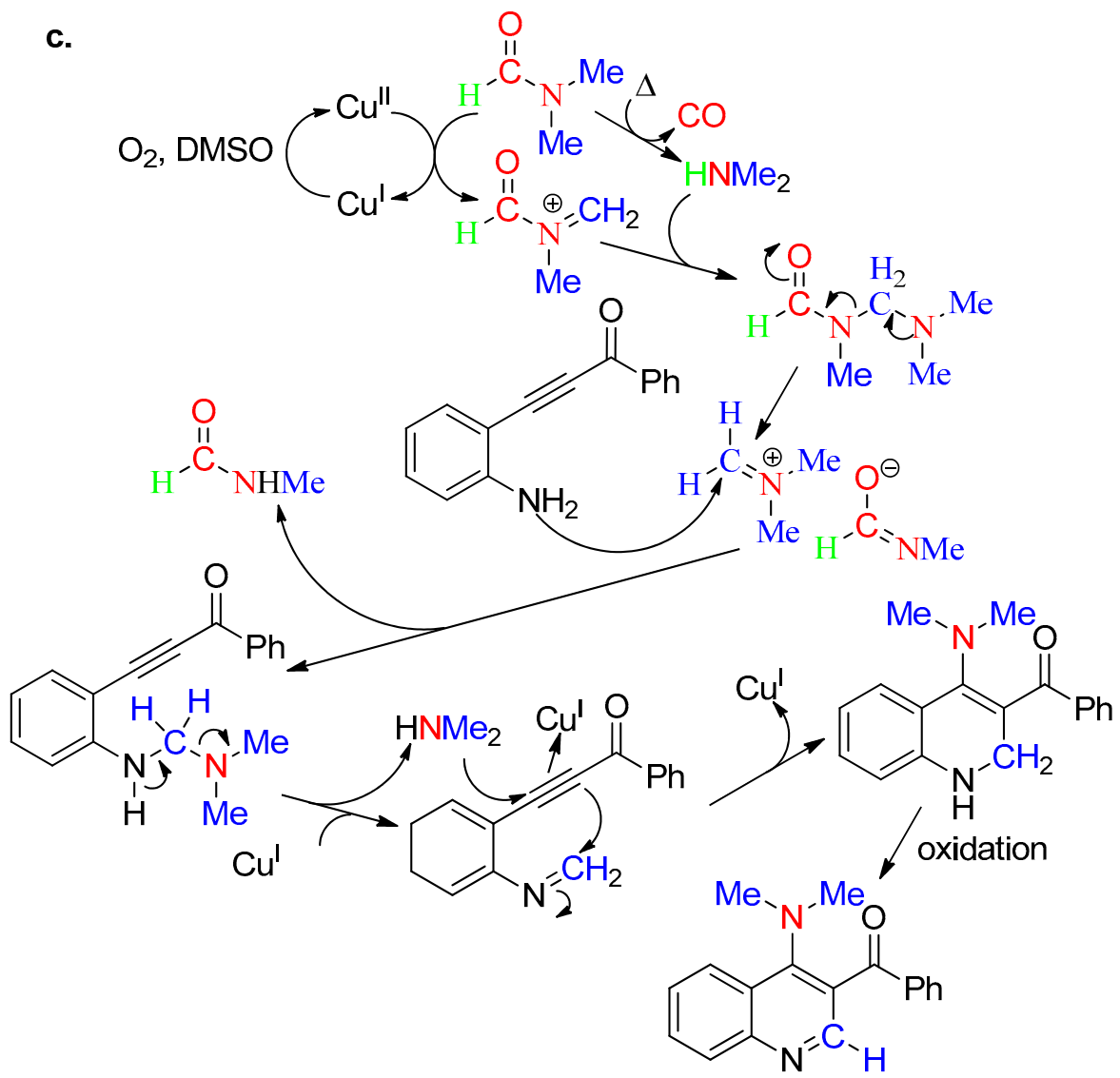

Scheme 50. Hydroamination or addition/cyclization/oxidation sequence.<smiles></smiles>

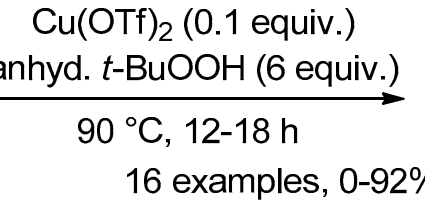

$\mathrm{Cu}(\mathrm{OTf})_{2}$ (0.1 equiv.)

$90^{\circ} \mathrm{C}, 12-18 \mathrm{~h}$

16 examples, $0-92 \%$

$$
\begin{gathered}
\mathrm{R}^{1}=\mathrm{H}, \mathrm{R}^{2}=\mathrm{H}(86 \%), \mathrm{Ph}(81 \%), m-\mathrm{O}_{2} \mathrm{NC}_{6} \mathrm{H}_{4}(75 \%), p-\mathrm{Me} \\
\quad p-\mathrm{F}_{3} \mathrm{CC}_{6} \mathrm{H}_{4}(74 \%), 2-\text { thienyl }(87 \%), i-\mathrm{Bu}(0 \%) \\
\mathrm{R}^{2}=\mathrm{Ph}, \mathrm{R}^{2}=7-\mathrm{OMe}(77 \%), 8-\mathrm{Br}(79 \%)
\end{gathered}
$$

Scheme 51. Aminomethylation.

\section{2. $\mathrm{CH}$ andN Fragments}

Recently, the Liu and Guo team disclosed the synthesis of symmetrical 3,5-diarylpy ridines from the $\mathrm{KI} / \mathrm{K}_{2} \mathrm{~S}_{2} \mathrm{O}_{8}$-mediated reaction of styrenes with $\mathrm{DM}$, especially DMF (Scheme 52( $\left.a_{1}\right)$ ) [160]. In contrast to the examples shown in Scheme 5( $\left.a_{2}\right)$, DM provided both the nitrogen atom and the methine fragment. The $\alpha, \beta$-unsaturated aldehyde depicted in Scheme 52 $\left(a_{2}\right)$ has been identified as intermediate. After the formation of the corresponding aldimine, [4 2] cycloaddition with styrene is followed by KI-mediated N-Me bond cleavage and aromatization. Unsymmetrical 3,5-diarylpyridines have been isolated using 1:1 mixtures of two different styrenes (Scheme $52\left(a_{3}\right)$ ). 


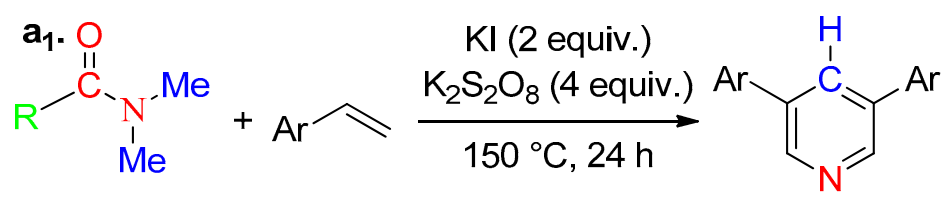

$\mathrm{R}=\mathrm{Me}, p-(t-\mathrm{Bu}) \mathrm{C}_{6} \mathrm{H}_{4}(50 \%)$

$\mathrm{R}=\mathrm{H}, 19$ examples, $40-71 \%$

$\mathrm{Ar}=\mathrm{Ph}(69 \%), o-\mathrm{MeC}_{6} \mathrm{H}_{4}(65 \%), p-(t-\mathrm{Bu}) \mathrm{C}_{6} \mathrm{H}_{4}(71 \%)$

$m-\mathrm{ClC}_{6} \mathrm{H}_{4}$ (57\%), 1-naphthyl (40\%), 2-thienyl (55\%)

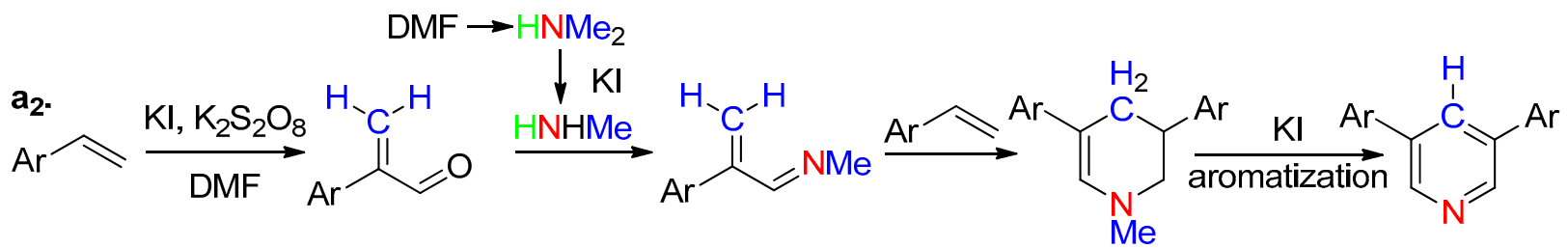

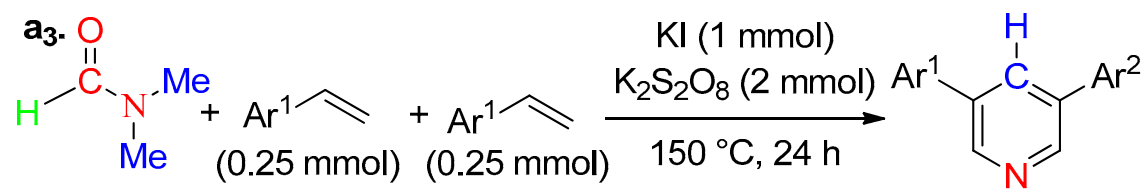

$$
\begin{aligned}
& \mathrm{Ar}^{1}=\mathrm{Ph}, \mathrm{Ar}^{2}=p-(t-\mathrm{Bu}) \mathrm{C}_{6} \mathrm{H}_{4}(45 \%) \\
& \mathrm{Ar}^{1}=p-\mathrm{MeC}_{6} \mathrm{H}_{4}, \mathrm{Ar}^{2}=p-\mathrm{MeOC}_{6} \mathrm{H}_{4}(39 \%), m-\mathrm{MeOC}_{6} \mathrm{H}_{4}(40 \%)
\end{aligned}
$$

Scheme 52. Annulation reaction between styrenes and DM.

\section{Conclusions}

The present review shows that various new procedures have continued to be disclosed over the last years using DMF and DMAc as sources of building blocks for the synthesis of an array of organic compounds. For processes involving atom(s) of the $\mathrm{Me}_{2} \mathrm{NCO}$ moiety of DM, efficiency and selectivity are usually higher with DMF than with DMAc. In contrast, the latter is generally the best for carbamoylation reactions. Intensive mechanism studies were sometimes required to determine the atom origin as exemplified for a rather banal reaction such as the formylation with $\mathrm{HCON}\left(\mathrm{CH}_{3}\right)_{2}$, the formyl moiety coming from $\mathrm{CO}$ $\mathrm{H}, \mathrm{CH}$ and $\mathrm{O}$ of $\mathrm{H}_{2} \mathrm{O}$, or $\mathrm{CH}$ and $\mathrm{O}$ of $\mathrm{O}_{2}$. Some uncertainty nevertheless remains for a few reactions.

Numerous procedures above documented have been used for syntheses with other amides as sources of building blocks; others could also be efficient. Another remark concern the alarm to the potential safety hazards associated with using DM in particular chemical conditions [161,162] and the toxicity of these solvents [163].

Funding: This research received no external funding.

Conflicts of Interest: The author declares no conflict of interest.

\section{References}

1. Muzart, J. N,N-Dimethylformamide: Much more than a solvent. Tetrahedron 2009, 65, 8313-8323. [CrossRef]

2. Le Bras, J.; Muzart, J. N,N-Dimethylformamide and $N, N$-dimethylacetamide as carbon, hydrogen, nitrogen and/or oxygen sources. In Solvents as Reagents in Organic Synthesis, Reactions and Applications; Wu, X.-F., Ed.; Wiley-VCH: Weinheim, Germany, 2017; pp. 199-314.

3. Le Bras, J.; Muzart, J. Recent uses of N,N-dimethylformamide and N,N-dimethylacetamide as reagents. Molecules 2018, $23,1939$. [CrossRef] [PubMed]

4. Ding, S.; Jiao, N. N,N-Dimethylformamide: A multipurpose building block. Angew. Chem. Int. Ed. 2012, 51, 9226-9231. [CrossRef] [PubMed]

5. Batra, A.; Singh, P.; Singh, K.N. Cross dehydrogenative coupling (CDC) reactions of $N, N$-disubstituted formamides, benzaldehydes and cycloalkanes. Eur. J. Org. Chem. 2016, 2016, 4927-4947. [CrossRef] 
6. Heravi, M.M.; Ghavidel, M.; Mohammadkhani, L. Beyond a solvent: Triple roles of dimethylformamide in organic chemistry. RSC Adv. 2018, 8, 27832-27862. [CrossRef]

7. Miyabe, H. Transition-metal-free activation of amide bond by arynes. Molecules 2018, 23, 2145. [CrossRef] [PubMed]

8. Liang, F.; Eda, K.; Okazoe, T.; Wada, A.; Mori, N.; Konishi, K.; Tsuda, A. Photo-on-demand synthesis of Vilsmeier reagents with chloroform and their applications to one-pot organic syntheses. J. Org. Chem. 2021, 86, 6504-6517. [CrossRef] [PubMed]

9. Felder, S.; Micouin, L.; Benedetti, E. Para-functionalization of N-substituted 4-amino[2.2]paracyclophanes by regioselective formylation. Eur. J. Org. Chem. 2021, 2021, 4015-4018. [CrossRef]

10. Sang, D.; Yue, H.; Zhao, Z.; Yang, P.; Tian, J. Anchimerically assisted selective cleavage of acid-labile aryl alkyl ethers by aluminum triiodide and $N, N$-dimethylformamide dimethyl acetal. J. Org. Chem. 2020, 85, 6429-6440. [CrossRef] [PubMed]

11. Xu, S.; Teng, J.; Yu, J.-T.; Sun, S.; Cheng, J. Copper-mediated direct cyanation of heteroarene and arene C-H bonds by the combination of ammonium and DMF. Org. Lett. 2019, 21, 9919-9923. [CrossRef] [PubMed]

12. Li, X.; Wang, S.; Zang, J.; Liu, M.; Jiang, G.; Ji, F. Copper- and DMF-mediated switchable oxidative C-H cyanation and formylation of imidazo[1,2-a]pyridines using ammonium iodide. Org. Biomol. Chem. 2020, 18, 9100-9108. [CrossRef]

13. Boos, V.; Bilakanti, V.; Velisoju, V.K.; Gutta, N.; Inkollu, S.; Akula, V. An insight on the influence of surface Lewis acid sites for regioselective $\mathrm{C}-\mathrm{H}$ bond $\mathrm{C}_{3}$-cyanation of indole using $\mathrm{NH}_{4} \mathrm{I}$ and $\mathrm{DMF}$ as combined cyanide source over Cu/SBA-15 catalyst. Mol. Catal. 2018, 445, 43-51. [CrossRef]

14. Ji, F.; Wang, S.; Jiang, G. Method for Constructing 2-Phenylimidazo[1,2-a]pyridine-3-carbonitrile by Using Dimethylformamide (DMF) and Ammonium Iodide as Cyanation Reagent. China Patent CN110372697 A, 25 October 2019.

15. Ji, F.; Wang, S.; Jiang, G. Preparation of 2-(2-Thiophenyl)imidazole[1,2-a]pyridine-3-nitrile. China Patent CN110386933 A, 29 October 2019.

16. Ji, F.; Wang, S.; Jiang, G. Method For Constructing 2-(2-Naphthyl)Imidazo[1,2-A]Pyridine-3-Carbonitrile By Using DMF And Ammonium Iodide As Cyanation Reagent. China Patent CN110437225 A, 12 November 2019.

17. Ji, F.; Wang, S.; Jiang, G. New Method For Four-Step Construction Of Drug Molecule Saripidem With DMF And Ammonium Iodide As Cyanation Reagent. China Patent CN110437226 A, 12 November 2019.

18. Ji, F.; Wang, S.; Jiang, G. One-Step Construction Method of 2-Phenylbenzo(d)imidazo(2,1-b)thiazole-3-carbonitrile by Using DMF and Ammonium Iodide as Cyanation Reagent. China Patent CN110437262 A, 12 November 2019.

19. Saikia, R.; Park, K.; Masuda, H.; Itoh, M.; Yamada, T.; Sajiki, H.; Mahanta, S.P.; Thakur, A.J.; Bora, U. Revisiting the synthesis of aryl nitriles: A pivotal role of CAN. Org. Biomol. Chem. 2021, 19, 1344-1351. [CrossRef]

20. Ganesan, B.; Senadi, G.C.; Guo, B.-C.; Hung, M.-Y.; Lin, W.-Y. A copper(II)-catalyzed annulative formylation of o-alkynylanilines with DMF: A single-step strategy for 3-formyl indoles. RSC Adv. 2018, 8, 40968-40973. [CrossRef]

21. Wang, S.; Wang, K.; Kong, X.; Zhang, S.; Jiang, G.; Jia, F. DMF as methine source: Copper-catalyzed direct annulation of hydrazides to 1,3,4-oxadiazoles. Adv. Synth. Catal. 2019, 361, 3986-3990. [CrossRef]

22. Ning, Y.; He, X.; Zuo, Y.; Cai, P.; Xie, M.; Wang, J.; Shang, Y. Rhodium(II) acetate-catalysed cyclization of pyrazol-5-amine and 1,3-diketone-2-diazo compounds using $N, N$-dimethylformamide as a carbon-hydrogen source: Access to pyrazolo[3,4-b]pyridines. Adv. Synth. Catal. 2019, 361, 3518-3524. [CrossRef]

23. Weng, Y.; Chen, H.; Li, N.; Yang, L.; Ackermann, L. Electrooxidative metal-free cyclization of 4-arylaminocoumarins with DMF as C1-source. Adv. Synth. Catal. 2021, 363, 2773-2777. [CrossRef]

24. Chen, J.; Ding, X.; Gao, Y.; Zhou, D.; Hider, R.; Ma, Y. Selectfluor-promoted synthesis of 2,4- and 2,6-diarylpyridines through annulation of aromatic ketones with an ammonium source in DMF. ChemistrySelect 2019, 4, 2404-2408. [CrossRef]

25. Pan, X.; Liu, Q.; Chang, L.; Yuan, G. Ammonium iodide-promoted cyclization of ketones with DMSO and ammonium acetate for synthesis of substituted pyridines. RSC Adv. 2015, 5, 51183-51187. [CrossRef]

26. Bai, Y.; Tang, L.; Huang, H.; Deng, G.-J. Synthesis of 2,4-diarylsubstituted-pyridines through a Ru-catalyzedfour component reaction. Org. Biomol. Chem. 2015, 13, 4404-4407. [CrossRef]

27. Jia, Z.; Wang, K.; Tan, B.; Gu, Y. Ruthenium complexes immobilized on functionalized knitted hypercrosslinked polymers as efficient and recyclable catalysts for organic transformations. Adv. Synth. Catal. 2017, 359, 78-88. [CrossRef]

28. Yuan, Z.; Li, N.; Zhu, C.; Xia, C. Copper-catalyzed synthesis of $\alpha$-amino nitriles through methyl transfer from DMF to aromatic amines. Chem. Commun. 2018, 54, 2854-2857. [CrossRef]

29. Tsai, J.-Y.; Chang, C.-S.; Huang, Y.-F.; Chen, H.-S.; Lin, S.-K.; Wong, F.F.; Huang, L.-J.; Kuo, S.-C. Investigation of amination in 4-chloro-2-phenylquinoline derivatives with amide solvents. Tetrahedron 2008, 64, 11751-11755. [CrossRef]

30. Yang, C.; Zhang, F.; Deng, G.-J.; Gong, H. Amination of aromatic halides and exploration of the reactivity sequence of aromatic halides. J. Org. Chem. 2019, 84, 181-190. [CrossRef]

31. Sanzhiev, N.; Potapova, M.I.; Krasnokutskaya, E.A.; Filimonov, V.D. A novel one-pot synthesis of N,N-dimethylaminopyridines by diazotization of aminopyridines in dimethylformamide in the presence of trifluoromethanesulfonic acid. Russ. J. Org. Chem. 2020, 56, 1023-1028. [CrossRef]

32. Li, J.; Huang, C.; Wen, D.; Zheng, Q.; Tu, B.; Tu, T. Nickel-catalyzed amination of aryl chlorides with amides. Org. Lett. 2021, 23, 687-691. [CrossRef]

33. Wang, H.; Zhang, S.-Q.; Hong, X. Computational studies on Ni-catalyzed amide C-N bond activation. Chem. Commun. 2019, 55, 11330-11341. [CrossRef] 
34. Chaudhari, M.B.; Gnanaprakasam, B. Recent advances in the metal-catalyzed activation of amide bonds. Chem. Asian J. 2019, 14, 76-93. [CrossRef]

35. Cai, Y.; Jiao, L.; Qiu, X.; Du, Z. Promotion mechanism of $\mathrm{H}_{2} \mathrm{O}$ for stereoselectivity in Pd(II)-catalyzed C-H arylation of diarylphosphinamides with arylboronic acids. Chem. Res. Chin. Univ. 2020, 36, 843-846. [CrossRef]

36. Li, G.; Szostak, M. Non-classical amide bond formation: Transamidation and amidation of activated amides and esters by selective $\mathrm{N}-\mathrm{C} / \mathrm{O}-\mathrm{C}$ cleavage. Synthesis 2020, 52, 2579-2599.

37. Ansari, T.N.; Sharma, S.; Bora, P.P.; Ogulu, D.; Parmar, S.; Gallou, F.; Kozlowski, P.M.; Handa, S. Photoassisted charge transfer between DMF and substrate: Facile and selective N,N-dimethylamination of fluoroarenes. ChemSusChem 2021, 14, $2704-2709$. [CrossRef] [PubMed]

38. Zhou, Z.; Yu, J.T.; Zhou, Y.N.; Jiang, Y.; Cheng, J. Aqueous MCRs of quaternary ammoniums, N-substituted formamides and sodium disulfide towards aryl thioamides. Org. Chem. Front. 2017, 4, 413-416. [CrossRef]

39. Jin, H.; Chen, X.; Qian, C.; Ge, X.; Zhou, S. Transition-metal-free, general construction of thioamides from chlorohydrocarbon, amide and elemental sulfur. Eur. J. Org. Chem. 2021, 3403-3406. [CrossRef]

40. Wei, J.; Li, Y.; Jiang, X. Aqueous compatible protocol to both alkyl and aryl thioamide synthesis. Org. Lett. 2016, 18, 340-343. [CrossRef] [PubMed]

41. Zhang, Z.; Yang, J.; Yu, R.; Wu, K.; Bu, J.; Li, S.; Qian, P.; Sheng, L. Efficient synthesis of $\alpha$-ketothioamides from $\alpha$-nitroketones, amines or DMF and elemental sulfur under oxidant-free conditions. Eur. J. Org. Chem. 2021, 5209-5212. [CrossRef]

42. Laha, J.K.; Patel, K.V.; Tummalapalli, K.S.S.; Hunjan, M.K. Palladium-catalyzed serendipitous synthesis of arylglyoxylic amides from arylglyoxylates and $N, N$-dialkylamides in the presence of halopyridines. ACS Omega 2018, 3, 8787-8793. [CrossRef]

43. Xie, D.; He, W.; Xiao, J.; Wu, Y.; Guo, Y.; Liu, Q.; Guo, C. Direct synthesis of 2-oxo-acetamidines from methyl ketones, aromatic amines and DMF via copper-catalyzed C $\left(\mathrm{sp}^{3}\right)-\mathrm{H}$ amidination. RSC Adv. 2019, 9, 7203-7209. [CrossRef]

44. Su, L.B.; Ren, T.B.; Dong, J.Y.; Liu, L.X.; Xie, S.M.; Yuan, L.; Zhou, Y.B.; Yin, S.F. Cu(I)-catalyzed 6-endo-dig cyclization of terminal alkynes, 2-bromoaryl ketones, and amides toward 1-naphthylamines: Applications and photophysical properties. J. Am. Chem. Soc. 2019, 141, 2535-2544. [CrossRef]

45. Rode, N.D.; Arcadi, A.; Chiarini, M.; Marinelli, F. An improved environmentally friendly approach to 4-nitro-, 4-sulfonyl-, and 4 -aminoquinolines and 4-quinolones through conjugate addition of nucleophiles to $\beta$-(2-aminophenyl)- $\alpha, \beta$-ynones. Synthesis 2017, 49, 2501-2512. [CrossRef]

46. Zheng, H.-X.; Shan, X.-H.; Qu, J.-P.; Kang, Y.-B. Transition-metal-free hydrogenation of aryl halides: From alcohol to aldehyde. Org. Lett. 2017, 19, 5114-5117. [CrossRef]

47. Niu, Y.-J.; Sui, G.-H.; Zheng, H.-X.; Shan, X.-H.; Tie, L.; Fu, J.-L.; Qu, J.-P.; Kang, Y.-B. Competing dehalogenation versus borylation of aryl iodides and bromides under transition-metal-free basic conditions. J. Org. Chem. 2019, 84, 10805-10813. [CrossRef]

48. Liu, Y.; Zhao, H.; Tian, G.; Du, F.; Qi, Y.; Wen, Y. A novel coupling reaction of a-halo ketones promoted by $\mathrm{SmI}_{3} / \mathrm{CuI}$. RSC Adv. 2016, 6, 26317-26322. [CrossRef]

49. Giannakopoulou, F.; Pardali, V.; Skrettas, I.; Zoidis, G. Transesterification instead of N-alkylation: An intriguing reaction. ChemistrySelect 2019, 4, 3195-3198. [CrossRef]

50. Minato, M.; Watanabe, H.; Shimizu, T.; Shibuya, T.; Yamamoto, R.; Ishikura, K.; Zhou, D.-Y. One-pot synthesis of polysiloxanes using catalytic reaction of dihydroorganosilanes with DMF: A new approach to functional polysiloxanes. J. Organomet. Chem. 2020, 928, 121550. [CrossRef]

51. Chen, Z.; Wang, L.-C.; Wu, X.-F. Carbonylative synthesis of heterocycles involving diverse CO surrogates. Chem. Commun. 2020, 56, 6016-6030. [CrossRef]

52. Thakur, V.; Kumar, A.; Sharma, N.; Shil, A.K.; Das, P. Supported palladium nanoparticles catalyzed reductive carbonylation of nitroarenes to $N$-arylformamides. Adv. Synth. Catal. 2018, 360, 432-437. [CrossRef]

53. Hajipour, A.R.; Tavangar-Rizi, Z. Straightforward and recyclable system for synthesis of biaryl ketones via carbonylative coupling reactions of aryl halides with $\mathrm{PhB}(\mathrm{OH})_{2}$ and (EtO) $)_{3} \mathrm{PhSi}$. ChemistrySelect 2017, 2, 8990-8999. [CrossRef]

54. De Robichon, M.; Bordessa, A.; Lubin-Germain, N.; Ferry, A. "CO" as a carbon bridge to build complex C2-branched glycosides using a palladium-catalyzed carbonylative Suzuki-Miyaura reaction from 2-iodoglycals. J. Org. Chem. 2019, 84, 3328-3339. [CrossRef]

55. Zoller, B.; Zapp, J.; Huy, P.H. Rapid organocatalytic formation of carbon monoxide: Application towards carbonylative cross couplings. Chem. Eur. J. 2020, 26, 9632-9638. [CrossRef]

56. Basu, P.; Riyajuddin, S.; Dey, T.K.; Ghosh, A.; Ghosh, K.; Islam, S.M. Synthesis and architecture of polystyrene-supported Schiff base-palladium complex: Catalytic features and functions in diaryl urea preparation in conjunction with Suzuki-Miyaura cross-coupling reaction by reductive carbonylation. J. Organomet. Chem. 2018, 877, 37-50. [CrossRef]

57. Zhou, X.; Zhang, G.; Gao, B.; Huang, H. Palladium-catalyzed hydrocarbonylative C-N coupling of alkenes with amides. Org. Lett. 2018, 20, 2208-2212. [CrossRef]

58. Barnard, P.J.; Levina, A.; Lay, P.A. Chromium(V) peptide complexes: synthesis and spectroscopic characterization. Inorg. Chem. 2005, 44, 1044-1053. [CrossRef]

59. Mohebali, H.; Mahjoub, A.R.; Karimi, M.; Heydari, A. Oxidative amidation of benzyl alcohol, benzaldehyde, benzoic acid styrene and phenyl acetylene catalyzed by ordered mesoporous HKUST-1-Cu: Effect of surface area on oxidative amidation reaction. Appl. Organomet. Chem. 2019, 33, e4822. [CrossRef] 
60. Shen, Z.-Y.; Cheng, J.-K.; Wang, C.; Yuan, C.; Loh, T.-P.; Hu, X.-H. Iron-catalyzed carbamoylation of enamides with formamides as a direct approach to $N$-acyl enamine amides. ACS Catal. 2019, 9, 8128-8135. [CrossRef]

61. Lu, M.; Lin, Z.; Chen, S.; Chen, H.; Huang, M.; Cai, S. Visible-light-enabled oxidative coupling of alkenes with dialkylformamides to access unsaturated amides. Org. Lett. 2019, 21, 9929-9933. [CrossRef]

62. Yan, X.-P.; Li, C.-K.; Zhou, S.-F.; Shoberu, A.; Zou, J.-P. Copper-catalyzed sp ${ }^{3}$-carbon radical/carbamoyl radical cross coupling: A direct strategy for carbamoylation of 1,3-dicarbonyl compounds. Tetrahedron 2020, 76, 131342. [CrossRef]

63. Vishwakarma, R. Copper supported Mg-Al hydrotalcite derived oxide catalyst for enol carbamate synthesis via $\mathrm{C}-\mathrm{H}$ bond activation of formamides. Catal. Commun. 2020, 147, 106150. [CrossRef]

64. Hassani, H.; Shaghayeghi Toosi, F.; Feizi, N. Oxidative coupling of dimethylformamide with $\beta$-dicarbonyl compounds using $\gamma-\mathrm{Fe}_{2} \mathrm{O}_{3} @ \mathrm{CuO}$ nanoparticles. Russ. J. Org. Chem. 2020, 56, 1654-1659. [CrossRef]

65. Chen, J.; Mao, J.; He, Y.; Shi, D.; Zou, B.; Zhang, G. AlCl 3 -promoted thiolation of acyl C-H bonds with arylsulfonyl hydrazides. Tetrahedron 2015, 71, 9496-9500. [CrossRef]

66. Bi, W.-Z.; Zhang, W.-J.; Li, Z.-J.; He, Y.-H.; Feng, S.-X.; Geng, Y.; Chen, X.-L.; Qu, L.-B. Visible-light-promoted synthesis of secondary and tertiary thiocarbamates from thiosulfonates and $N$-substituted formamides. Org. Biomol. Chem. 2021, 19, 8701-8705. [CrossRef]

67. Liang, Q.; Walsh, P.J.; Jia, T. Copper-catalyzed intermolecular difunctionalization of styrenes with thiosulfonates and arylboronic acids via a radical relay pathway. ACS Catal. 2020, 10, 2633-2639. [CrossRef]

68. Deng, J.-C.; Zhang, J.-R.; Li, M.-H.; Huang, J.-C.; Lai, Z.-S.; Tong, X.-Y.; Cui, Z.-N.; Tang, R.-Y. Direct thiocarbamation of imidazoheterocycles via dual C-H sulfurization. Org. Biomol. Chem. 2019, 17, 7854-7857. [CrossRef] [PubMed]

69. Dourtoglou, V.; Ziegler, J.-C.; Gross, B. L'hexafluorophosphate de O-benzotriazolyl-N,N-tetramethyluronium: Un reactif de couplage peptidique nouveau et efficace. Tetrahedron Lett. 1978, 19, 1269-1272. [CrossRef]

70. Knorr, R.; Trzeciak, A.; Bannwarth, W.; Gillessen, D. New coupling reagents in peptide chemistry. Tetrahedron Lett. 1989, 30, 1927-1930. [CrossRef]

71. Carpino, L.; Imazumi, H.; El-Faham, A.; Ferrer, F.J.; Zhang, C.; Lee, Y.; Foxman, B.M.; Henklein, P.; Hanay, C.; Mügge, C.; et al. The uronium/guanidinium peptide coupling reagents: Finally the true uronium salts. Angew. Chem. Int. Ed. 2002, 41, 441-445. [CrossRef]

72. Yang, Y.; Hansen, L.; Sjögren, J.K.; León, I.R.; Receveur, J.-M.; Badalassi, F. Impurity dimethylcarbamoyl-OBt detected in an API induced by the degradation of HBTU in DMF. Org. Process Res. Dev. 2021, 25, 1923-1931. [CrossRef]

73. Ye, R.; Hao, F.; Liu, G.; Zuo, Q.; Deng, L.; Jin, Z.; Wu, J. DMF/NaOH/H $\mathrm{H}_{2} \mathrm{O}$ : A metal-free system for efficient and chemoselective reduction of $\alpha$-ketoamides. Org. Chem. Front. 2019, 6, 3562-3565. [CrossRef]

74. Ding, T.-H.; Qu, J.-P.; Kang, Y.-B. Visible-light-induced, base-promoted transition-metal-free dehalogenation of aryl fluorides, chlorides, bromides, and iodides. Org. Lett. 2020, 22, 3084-3088. [CrossRef]

75. Bergès, J.; Zaid, Y.; Tlili, A.; Sotiropoulos, J.-M.; Taillefer, M. Transition-metal-free Matsuda-Heck type cross-coupling and mechanistic evidence for a radical mechanism. Eur. J. Org. Chem. 2021, 1559-1563. [CrossRef]

76. Mostafavi, M.R.; Islami, E.; Ghonchepour, A.M. Tikdari, Synthesis of 1H-1,3-benzimidazoles, benzothiazoles and 3H-imidazo[4,5c]pyridine using DMF in the presence of HMDS as a reagent under the transition-metal-free condition. Chem. Pap. 2018, 72, 2973-2978. [CrossRef]

77. Gan, Z.; Tian, Q.; Shang, S.; Luo, W.; Dai, Z.; Wang, H.; Li, D.; Wang, X.; Yuan, J. Imidazolium chloride-catalyzed synthesis of benzimidazoles and 2-substituted benzimidazoles from o-phenylenediamines and DMF derivatives. Tetrahedron 2018, 74, 7450-7456. [CrossRef]

78. Xu, Y.; Shen, B.; Liu, L.; Qiao, C. Metal free [4+1] and [5+1] annulation reactions to prepare heterocycles using DMF and its derivatives as one-carbon source. Tetrahedron Lett. 2020, 61, 151844. [CrossRef]

79. Wang, X.; Shang, S.; Tian, Q.; Wang, Y.; Wu, H.; Li, Z.; Zhou, S.; Liu, H.; Dai, Z.; Luo, W.; et al. Imidazolium chloride as an additive for synthesis of 4(3H)-quinazolinones using anthranilamides and DMF derivatives. Tetrahedron 2020, 76, 131480. [CrossRef]

80. Xia, H.-M.; Zhang, F.-L.; Ye, T.; Wang, Y.-F. Selective $\alpha$-monomethylation by an amine-borane/ $N$, $N$-dimethylformamide system as the methyl source. Angew. Chem. Int. Ed. 2018, 57, 11770-11775. [CrossRef]

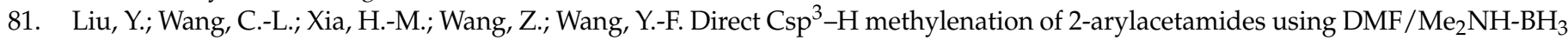
as the methylene source. Org. Biomol. Chem. 2019, 17, 6153-6157. [CrossRef]

82. Meng, J.; Xia, H.-M.; Xu, A.-Q.; Wang, Y.-F.; Wang, Z.; Zhang, F.-L. Selective N-monomethylation of primary anilines with the controllable installation of $\mathrm{N}-\mathrm{CH}_{2} \mathrm{D}, \mathrm{N}-\mathrm{CHD}_{2}$, and $\mathrm{N}-\mathrm{CD}_{3}$ units. Org. Biomol. Chem. 2020, 18, 4922-4926. [CrossRef]

83. Li, L.-H.; Niu, Z.-J.; Liang, Y.-M. New Friedel-Crafts strategy for preparing 3-acylindoles. Org. Biomol. Chem. 2018, 16, 7792-7796. [CrossRef]

84. Tashrifi, Z.; Mohammadi-Khanaposhtani, M.; Larijani, B.; Mahdavi, M. Triflic anhydride (Tf ${ }_{2} \mathrm{O}$ ): An efficient catalyst for electrophilic activation of amides. ChemistrySelect 2021, 6, 5320-5328. [CrossRef]

85. Liu, Y.; Xia, Y.-T.; Cui, S.-H.; Ji, Y.-G.; Wu, L. Palladium-catalyzed cascade hydrosilylation and amino-methylation of isatin derivatives. Adv. Synth. Catal. 2020, 362, 2632-2636. [CrossRef]

86. Leung, V.M.-Y.; Gieuw, M.H.; Ke, Z.; Yeung, Y.Y. Intermolecular electrophilic bromoesterification and bromoetherification of unactivated cyclopropanes. Adv. Synth. Catal. 2020, 362, 2039-2044. [CrossRef] 
87. Zhao, H.; Dankwardt, J.W.; Koenig, S.G.; Singh, S.P. Directed metalation and regioselective functionalization of 3-bromofuran and related heterocycles with NaHMDS. Tetrahedron Lett. 2012, 53, 166-169. [CrossRef]

88. Shigeno, M.; Fujii, Y.; Kajima, A.; Nozawa-Kumada, K.; Kondo, Y. Catalytic deprotonative $\alpha$-formylation of heteroarenes by an amide base generated in situ from tetramethylammonium fluoride and tris(trimethylsilyl)amine. Org. Process Res. Dev. 2019, 23, 443-451. [CrossRef]

89. Acosta-Guzmán, P.; Mateus-Gómez, A.; Gamba-Sánchez, D. Direct transamidation reactions: Mechanism and recent advances. Molecules 2018, 23, 2382. [CrossRef]

90. Yang, D.; Jeon, H.B. Convenient $N$-formylation of amines in dimethylformamide with methyl benzoate under microwave irradiation. Bull. Korean Chem. Soc. 2010, 31, 1424-1426. [CrossRef]

91. Rao, S.N.; Mohan, D.C.; Adimurthy, S. L-Proline: An efficient catalyst for transamidation of carboxamides with amines. Org. Lett. 2013, 15, 1496-1499. [CrossRef]

92. Becerra-Figueroa, L.; Ojeda-Porras, A.; Gamba-Sánchez, D. Transamidation of carboxamides catalyzed by Fe(III) and water. J. Org. Chem. 2014, 79, 4544-4552. [CrossRef]

93. Hussein, M.A.; Dinh, A.H.; Huynh, V.T.; Nguyen, T.V. Synthesis of tertiary amines by direct Brønsted acid catalyzed reductive amination. Chem. Commun. 2020, 56, 8691-8694. [CrossRef]

94. Yin, J.; Zhang, J.; Cai, C.; Deng, G.-J.; Gong, H. Catalyst-free transamidation of aromatic amines with formamide derivatives and tertiary amides with aliphatic amines. Org. Lett. 2019, 21, 387-392. [CrossRef]

95. Tan, Z.; Li, Z.; Ma, Y.; Qin, J.; Yu, C. Potassium tert-butoxide prompted highly efficient transamidation and its coordination radical mechanism. Eur. J. Org. Chem. 2019, 4538-4545. [CrossRef]

96. Ghosh, T.; Jana, S.; Dash, J. KO ${ }^{t}$ Bu-promoted transition-metal-free transamidation of primary and tertiary amides with amines. Org. Lett. 2019, 21, 6690-6694. [CrossRef]

97. Zhang, R.; Zhang, J.-C.; Zhang, W.-Y.; He, Y.-Q.; Cheng, H.; Chen, C.; Gu, Y.-C. A practical approach for the transamidation of $\mathrm{N}, \mathrm{N}$-dimethyl amides with primary amines promoted by sodium tert-butoxide under solvent-free conditions. Synthesis 2020, 52, 3286-3294.

98. Tian, Q.; Gan, Z.; Wang, X.; Li, D.; Luo, W.; Wang, H.; Dai, Z.; Yuan, J. Imidazolium chloride: An efficient catalyst for transamidation of primary amines. Molecules 2018, 23, 2234. [CrossRef] [PubMed]

99. Chen, J.; Jia, J.; Guo, Z.; Zhang, J.; Xie, M. NH 4 I-promoted N-acylation of amines via the transamidation of DMF and DMA under metal-free conditions. Tetrahedron Lett. 2019, 60, 1426-1429. [CrossRef]

100. Chen, C.; Tan, L.; Zhou, P. Approach for the synthesis of $N$-phenylamides from $\beta$-ketobutylanilides using dimethylformamide and dimethylacetamide as the acyl donors. J. Saudi Chem. Soc. 2015, 19, 327-333. [CrossRef]

101. Zhang, Q.; Chen, C. Direct Acylation of aryl amines using dimethylformamide and dimethylacetamide as the acyl resources. J. Saudi Chem. Soc. 2016, 20, 114-119. [CrossRef]

102. Dhawan, S.; Girase, P.S.; Kumar, V.; Karpoormath, R. HCl-mediated transamidation of unactivated formamides using aromatic amines in aqueous media. Synth. Commun. 2021, in press. [CrossRef]

103. Ramírez-Vázquez, D.G.; Viñas-Bravo, O.; Martínez-Pascual, R.; Pérez-Picaso, L.; Castro-Cerritos, K.V. DMF.HCl as a versatile and straightforward $N$ - and $O$-formylating agent. Synth. Commun. 2021, 51, 585-592. [CrossRef]

104. Yang, Y.; Li, Y.; Zhang, Z.; Zhao, Y.; Feng, W. Metal-free N-formylation of 2-aminophenols using dimethylformamide and CSA. Synth. Commun. 2019, 49, 1040-1046. [CrossRef]

105. Sakurai, M.; Kawakami, R.; Kihara, N. TBSOTf-promoted versatile N-formylation using DMF at room temperature. Tetrahedron Lett. 2019, 60, 1291-1294. [CrossRef]

106. Bhattacharya, S.; Ghoh, P.; Basu, B. Graphene oxide (GO) catalyzed transamidations of aliphatic amides: An efficient metal-free procedure. Tetrahedron Lett. 2018, 59, 899-903. [CrossRef]

107. Sonawane, R.B.; Rasal, N.K.; Bhange, D.S.; Jagtap, S.V. Copper-(II) catalyzed N-formylation and N-acylation of aromatic, aliphatic and heterocyclic amines and a preventive study in the $\mathrm{C}-\mathrm{N}$ cross coupling of amines with aryl halides. Chem CatChem 2018, 10, 3907-3913. [CrossRef]

108. Li, C.; Wang, M.; Lu, X.; Yang, Y.; Zhang, L. Pd-catalyzed N-formylation of amines with N,N-dimethylformamide. Chin. J. Org. Chem. 2019, 39, 1109-1115. [CrossRef]

109. Ma, J.; Zhang, F.; Zhang, J.; Gong, H. Cobalt(II)-catalyzed N-acylation of amines through a transamidation reaction. Eur. J. Org. Chem. 2018, 4940-4948. [CrossRef]

110. Toyao, T.; Rashed, M.N.; Morita, Y.; Kamachi, T.; Siddiki, S.M.A.H.; Ali, M.A.; Touchy, A.S.; Kon, K.; Maeno, Z.; Yoshizawa, K.; et al. Esterification of tertiary amides by alcohols through $\mathrm{C}-\mathrm{N}$ bond cleavage over $\mathrm{CeO}_{2}$. ChemCatChem 2019, 11, 449-456. [CrossRef]

111. Zhuang, D.; Gatera, T.; Yan, R. CuBr 2 -catalyzed ring opening/formylation reaction of cyclopropyl carbinols with DMF to synthesize formate esters. Tetrahedron Lett. 2020, 61, 152506. [CrossRef]

112. Xue, P.; Huang, J.; Lin, L.; Li, R.; Tang, M.; Wang, Z. Zirconium-based metal-organic framework as an efficiently heterogeneous photocatalyst for oxidation of benzyl halides to aldehydes. Mol. Catal. 2021, 506, 111542. [CrossRef]

113. Zheng, P.; Zhai, Y.; Zhao, X.; Xu, T. Difunctionalization of ketones via gem-bis(boronates) to synthesize quaternary carbon with high selectivity. Chem. Commun. 2018, 54, 13375-13378. [CrossRef] 
114. Zheng, P.; Zhai, Y.; Zhao, X.; Xu, T. Palladium-catalyzed cross-coupling of gem-bis(boronates) with aryl halides: An alternative to access quaternary $\alpha$-aryl aldehydes. Org. Lett. 2019, 21, 393-396. [CrossRef]

115. Arnone, A.; Cecere, M.; Galli, R.; Minisci, F.; Perchinunno, M.; Porta, O.; Gardini, G. Nucleophilic character of carbon free radicals. New convenient substitution of heteroaromatic bases: The homolytic amidations. Gazz. Chim. Ital. 1973, 103, 13-29. [CrossRef]

116. Citterio, A.; Gentile, A.; Minisci, F.; Serravalle, M.; Ventura, S. Redox-chain decomposition of hydroxylamine-O-sulphonic acid. a novel general source of nucleophilic radicals for the functionalization of heteroaromatic bases. J. Chem. Soc. Chem. Commun. 1983, 916-917. [CrossRef]

117. Citterio, A.; Gentile, A.; Minisci, F.; Serravalle, M.; Ventura, S. Polar effects in free-radical reactions. Carbamoylation and.alpha.$\mathrm{N}$-amidoalkylation of heteroaromatic bases by amides and hydroxylamine-O-sulfonic acid. J. Org. Chem. 1984, 49, 3364-3367. [CrossRef]

118. Minisci, F.; Giordano, C.; Vismara, E.; Levi, S.; Tortelli, V. Polar effects in free radical reactions. Induced decompositions of peroxo compounds in the substitution of heteroaromatic bases by nucleophilic radicals. J. Am. Chem. Soc. 1984, 106, 7146-7150. [CrossRef]

119. Caronna, T.; Gambarotti, C.; Palmisano, L.; Punta, C.; Recupero, F. Sunlight induced functionalisation of some heterocyclic bases in the presence of polycrystalline $\mathrm{TiO}_{2}$. Chem. Commun. 2003, 2350-2351. [CrossRef] [PubMed]

120. Wang, J.; Li, J.; Huang, J.; Zhu, Q. Transition metal-free amidoalkylation of benzothiazoles and amidoalkylarylation of activated alkenes with $N, N$-dialkylamides. J. Org. Chem. 2016, 81, 3017-3022. [CrossRef] [PubMed]

121. Weng, J.-Q.; Xu, W.-X.; Dai, X.-Q.; Zhang, J.-H.; Liu, X.-H. Alkylation reactions of benzothiazoles with $N, N-d i m e t h y l a m i d e s$ catalyzed by the two-component system under visible light. Tetrahedron Lett. 2019, 60, 390-396. [CrossRef]

122. Okugawa, N.; Moriyama, K.; Togo, H. Introduction of quinolines and isoquinolines onto nonactivated $\alpha-\mathrm{C}-\mathrm{H}$ bond of tertiary amides through a radical pathway. J. Org. Chem. 2017, 82, 170-178. [CrossRef]

123. Truscello, A.M.; Gambarotti, C. Revisiting the Minisci reaction: New mild amidoalkylation of benzo-fused N-heteroaromatic bases under metal-free conditions. Org. Process Res. Dev. 2019, 23, 1450-1457. [CrossRef]

124. Zhou, J.; Ren, Q.; Xu, N.; Wang, C.; Song, S.; Chen, Z.; Li, J. $\mathrm{K}_{2} \mathrm{~S}_{2} \mathrm{O}_{8}$-catalyzed highly regioselective amidoalkylation of diverse $\mathrm{N}$-heteroaromatics in water under visible light irradiation. Green Chem. 2021, 23, 5753-5758. [CrossRef]

125. Lv, N.; Yu, S.; Hong, C.; Han, D.-M.; Zhang, Y. Selectively oxidative C( $\left.\mathrm{sp}^{2}\right)-\mathrm{H} / \mathrm{C}\left(\mathrm{sp}^{3}\right)-\mathrm{H}$ cross-coupling of benzamides with amides by nickel catalysis. Org. Lett. 2020, 22, 9308-9312. [CrossRef]

126. Yan, H.; Lu, L.; Rong, G.; Liu, D.; Zheng, Y.; Chen, J.; Mao, J. Functionalization of amides via copper-catalyzed oxyalkylation of vinylarenes and decarboxylative alkenylation of $\mathrm{sp}^{3}$ C-H. J. Org. Chem. 2014, 79, 7103-7111. [CrossRef]

127. Song, R.-J.; Tu, Y.-Q.; Zhu, D.-Y.; Zhanga, F.-M.; Wang, S.-H. A nickel-mediated oxidative $\alpha-C\left(\mathrm{sp}^{3}\right)-\mathrm{H}$ functionalization of amides with allylic alcohols terminated by radical 1,2-aryl migration. Chem. Commun. 2015, 51, 749-752. [CrossRef]

128. Paul, S.; Guin, J. Radical C $\left(\mathrm{sp}^{3}\right)-\mathrm{H}$ alkenylation, alkynylation and allylation of ethers and amides enabled by photocatalysis. Green Chem. 2017, 19, 2530-2534. [CrossRef]

129. Li, M.; Zheng, L.; Ma, L.; Chen, Y. Transition metal-free oxidative cross-coupling reaction of activated olefins with N-alkyl amides. J. Org. Chem. 2021, 86, 3989-3998. [CrossRef]

130. Kawamorita, S.; Miyazaki, T.; Iwai, T.; Ohmiya, H.; Sawamura, M. Rh-catalyzed borylation of N-adjacent C(sp $\left.{ }^{3}\right)-H$ bonds with a silica-supported triarylphosphine ligand. J. Am. Chem. Soc. 2012, 134, 12924-12927. [CrossRef]

131. Iwai, T.; Murakami, R.; Harada, T.; Kawamorita, S.; Sawamura, M. Silica-supported tripod triarylphosphane: Application to transition metal-catalyzed C $\left(\mathrm{sp}^{3}\right)-\mathrm{H}$ borylations. Adv. Synth. Catal. 2014, 356, 1563-1570. [CrossRef]

132. Hyland, S.N.; Meck, E.A.; Tortosa, M.; Clark, T.B. $\alpha$-Amidoboronate esters by amide-directed alkane C-H borylation. Tetrahedron Lett. 2019, 60, 1096-1098. [CrossRef]

133. Zhang, X.; Geng, P.; Liu, G.; Huang, Z. Ru-catalyzed site-selective aliphatic C-H bond silylation of amides and carbamides. Organometallics 2021, 40, 2365-2370. [CrossRef]

134. Pan, L.; Elmasry, J.; Osccorima, T.; Cooke, M.V.; Laulhé, S. Photochemical regioselective C(sp $\left.{ }^{3}\right)-\mathrm{H}$ amination of amides using N-haloimides. Org. Lett. 2021, 23, 3389-3393. [CrossRef]

135. Reyes, R.L.; Iwai, T.; Maeda, S.; Sawamura, M. Iridium-catalyzed asymmetric borylation of unactivated methylene C( $\left.\mathrm{sp}^{3}\right)-\mathrm{H}$ bonds. J. Am. Chem. Soc. 2019, 141, 6817-6821. [CrossRef]

136. Reyes, R.L.; Sato, M.; Iwai, T.; Sawamura, M. Asymmetric synthesis of $\alpha$-aminoboronates via rhodium-catalyzed enantioselecitve C $\left(\mathrm{sp}^{3}\right)$-H borylation. J. Am. Chem. Soc. 2020, 142, 589-597. [CrossRef]

137. Matsuda, T.; Tabata, Y.; Suzuki, H. Silver-catalyzed ring-opening [3+2] annulation of cyclopropenones with amides. New J. Chem. 2018, 42, 19178-19182. [CrossRef]

138. Luo, Z.-B.; Wang, Y.-W.; Peng, Y. Base-promoted addition of DMA with 1,1-diarylethylenes: Application to a total synthesis of (-)-sacidumlignan B. Org. Biomol. Chem. 2020, 18, 2054-2057. [CrossRef]

139. Yamashita, Y.; Igarashi, R.; Suzuki, H.; Kobayashi, S. Catalytic alkylation reactions of weakly acidic carbonyl and related compounds using alkenes as electrophiles. Org. Biomol. Chem. 2018, 16, 5969-5972. [CrossRef]

140. Chakraborty, S.; Daw, P.; Ben David, Y.; Milstein, D. Manganese-catalyzed $\alpha$-alkylation of ketones, esters, and amides using alcohols. ACS Catal. 2018, 8, 10300-10305. [CrossRef]

141. Rana, J.; Gupta, V.; Balaraman, E. Manganese-catalyzed direct C-C coupling of $\alpha-C-H$ bonds of amides and esters with alcohols via hydrogen autotransfer. Dalton Trans. 2019, 48, 7094-7099. [CrossRef] 
142. Jang, Y.K.; Krückel, T.; Rueping, M.; El-Sepelgy, O. Sustainable alkylation of unactivated esters and amides with alcohols enabled by manganese catalysis. Org. Lett. 2018, 20, 7779-7783. [CrossRef] [PubMed]

143. Gong, D.; Hu, B.; Yang, W.; Chen, D. Bidentate Ru(II)-NC complexes as catalysts for $\alpha$-alkylation of unactivated amides and esters. Chem CatChem 2019, 11, 4841-4847. [CrossRef]

144. Midya, S.P.; Rana, J.; Pitchaimani, J.; Nandakumar, A.; Madhu, V.; Balaraman, E. Ni-catalyzed $\alpha$-alkylation of unactivated amides and esters with alcohols by hydrogen auto-transfer strategy. ChemSusChem 2018, 11, 3911-3916. [CrossRef]

145. Yang, P.; Wang, X.; Ma, Y.; Sun, Y.; Zhang, L.; Yue, J.; Fu, K.; Zhou, J.S.; Tang, B. Nickel-catalyzed C-alkylation of thioamide, amides and esters by primary alcohols through a hydrogen autotransfer strategy. Chem. Commun. 2020, 56, 14083-14086. [CrossRef] [PubMed]

146. Azizi, K.; Madsen, R. Radical condensation between benzylic alcohols and acetamides to form 3-arylpropanamides. Chem. Sci. 2020, 11, 7800-7806. [CrossRef] [PubMed]

147. Wu, X.; Zhao, Y.; Ge, H. Direct aerobic carbonylation of $\mathrm{C}\left(\mathrm{sp}^{2}\right)-\mathrm{H}$ and $\mathrm{C}\left(\mathrm{sp}^{3}\right)-\mathrm{H}$ bonds through Ni/Cu synergistic catalysis with DMF as the carbonyl source. J. Am. Chem. Soc. 2015, 137, 4924-4927. [CrossRef]

148. Yu, B.; Bodinier, F.; Saague-Tenefo, M.; Gerardo, P.; Ardisson, J.; Lannou, M.I.; Sorin, G. One-pot synthesis of $\alpha$-amino nitrile units through alkylative Strecker cyanation from formamides. Eur. J. Org. Chem. 2021, 3634-3640. [CrossRef]

149. Sharma, A.; Gogoi, P. 2-Formylarylsulfonate from aryne: A sequential reaction strategy for direct synthesis of ortho-hydroxylprotected aryl aldehydes. ChemistrySelect 2017, 2, 11801-11805. [CrossRef]

150. Neog, K.; Das, B.; Gogoi, P. 2,3-Diaroyl benzofurans from arynes: Sequential synthesis of 2-aroyl benzofurans followed by benzoylation. Org. Biomol. Chem. 2018, 16, 3138-3150. [CrossRef]

151. Song, B.; Zhang, D.; Xiao, S.; Liu, C.; Chen, H.; Qi, Y.; Liu, Y. Access to diarylmethanol skeletons via a samarium/copper-mediated sequential three-component $\mathrm{C}-\mathrm{H}$ functionalization reaction. J. Org. Chem. 2021, 86, 9854-9860. [CrossRef]

152. Yang, L.; Lin, J.; Kang, L.; Zhou, W.; Ma, D.-Y. Lewis acid-catalyzed reductive amination of aldehydes and ketones with $\mathrm{N}, \mathrm{N}$-dimethylformamide as dimethylamino source, reductant and solvent. Adv. Synth. Catal. 2018, 360, 485-490. [CrossRef]

153. Zhang, H.; Tong, X.; Liu, Z.; Wan, J.; Yu, L.; Zhang, Z. The sustainable heterogeneous catalytic reductive amination of lignin models to produce aromatic tertiary amines. Catal. Sci. Technol. 2018, 8, 5396-5400. [CrossRef]

154. Ghosh, T.; Mohammad, A.; Mobin, S.M. Hybrid cobalt doped-cerium oxide as a multifunctional nanocatalyst for various organic transformations. ACS Sustainable Chem. Eng. 2019, 7, 13746-13763. [CrossRef]

155. Rode, N.D.; Abdalghani, I.; Arcadi, A.; Aschi, M.; Chiarini, M.; Marinelli, F. Synthesis of 2-acylindoles via Ag- and Cu-catalyzed anti-Michael hydroamination of $\beta \beta$-(2-aminophenyl)- $\alpha, \beta$-ynones: Experimental results and DFT calculations. J. Org. Chem. 2018, 83, 6354-6362. [CrossRef]

156. Ganesan, B.; Govprovidindan, K.; Senadi, G.C.; Kandasamy, M.; Lin, W.Y. Copper-catalyzed synthesis of aminoquinolines from b-(2-aminophenyl)-a,b-ynones using DMF as dual synthon. Chem. Commun. 2020, 56, 6488-6491. [CrossRef]

157. Larock, R.C.; Hightower, T.R. Synthesis of unsaturated lactones via palladium-catalyzed cyclization of alkenoic acids. J. Org. Chem. 1993, 58, 5298-5300. [CrossRef]

158. Muzart, J. Oxidation adjacent to oxygen of alcohols catalyzed by palladium/dimethyl sulfoxide. In Comprehensive Organic Synthesis, 2nd ed.; Molander, G.A., Knochel, P., Eds.; Elsevier: Oxford, UK, 2014; Volume 7, pp. 295-301.

159. Ghosh, P.; Samanta, S.; Ghosh, S.; Jana, S.; Hajra, A. Aminomethylation of imidazopyridines using $N, N$-dimethylformamide as an aminomethylating reagent under $\mathrm{Cu}(\mathrm{II})$-catalysis. Tetrahedron Lett. 2020, 61, 152581. [CrossRef]

160. Su, M.-D.; Liu, H.-P.; Cao, Z.-Z.; Liu, Y.; Li, H.; Nie, Z.-W.; Yang, T.-L.; Luo, W.-P.; Liu, Q.; Guo, C.C. Two C=C bond participation in annulation to pyridines based on DMF as the nonadjacent $\mathrm{N}$ and $\mathrm{C}$ atom donors. J. Org. Chem. 2021, 86, 13446-13453. [CrossRef] [PubMed]

161. Yang, Q.; Sheng, M.; Henkelis, J.J.; Tu, S.; Wiensch, E.; Zhang, H.; Zhang, Y.; Tucker, C.; Ejeh, D.E. Explosion hazards of sodium hydride in dimethyl sulfoxide, $N, N$-dimethylformamide and $N, N$-dimethylacetamide. Org. Process Res. Dev. 2019, 23, $2210-2217$. [CrossRef]

162. Yang, Q.; Sheng, M.; Huang, Y. Potential safety hazards associated with using $N, N$-dimethylformamide in chemical reactions. Org. Process Res. Dev. 2020, 24, 1586-1601. [CrossRef]

163. Liu, Z.; He, Q.; Liu, Y.; Zhang, Y.; Cui, M.; Peng, H.; Wang, Y.; Chen, S.; Li, D.; Chen, L.; et al. Hsa_circ_0005915 promotes N,N-dimethylformamide-induced oxidative stress in HL-7702 cells through NRF2/ARE axis. Toxicology 2021, $458,152838$. [CrossRef] 